THE EFFECT OF SCIENCE CENTRES ON STUDENTS' ATTITUDES TOWARDS SCIENCE

\author{
A THESIS SUBMITTED TO \\ GRADUATE SCHOOL OF NATURAL AND APPLIED SCIENCES \\ OF \\ MIDDLE EAST TECHNICAL UNIVERSITY
}

BY

ERAY ŞENTÜRK

IN PARTIAL FULFILLMENT OF THE REQUIREMENTS FOR

THE DEGREE OF MASTER OF SCIENCE

IN

SECONDARY SCIENCE AND MATHEMATICS EDUCATION

SEPTEMBER 2009 
Approval of the thesis:

\section{THE EFFECT OF SCIENCE CENTRES ON STUDENTS'ATTITUDES TOWARDS SCIENCE}

submitted by ERAY ŞENTÜRK in partial fulfilment of the requirements for the degree of Master of Science in Secondary Science and Mathematics Education Department, Middle East Technical University by,

Prof. Dr. Canan Özgen

Dean, Graduate School of Natural and Applied Sciences

Prof. Dr. Ömer Geban

Head of Department, Secondary Science and Mathematics Education

Assist. Prof. Dr. Ömer Faruk Özdemir

Supervisor, Secondary Science and Mathematics Education Dept., METU

Examining Committee Members:

Assoc. Prof. Dr. Safure Bulut

Secondary Science and Mathematics Education Dept., METU

Assist. Prof. Dr. Ömer Faruk Özdemir

Secondary Science and Mathematics Education Dept., METU

Assoc. Prof. Dr. Semra Sungur

Elementary Education Dept., METU

Assist. Prof. Dr. A. Kürşat Erbaş

Secondary Science and Mathematics Education Dept., METU

Instructor Dr. Ufuk Yildirım

Secondary Science and Mathematics Education Dept., METU

Date: 10.09 .2009 
I hereby declare that all information in this document has been obtained and presented in accordance with academic rules and ethical conduct. I also declare that, as required by these rules and conduct, I have fully cited and referenced all material and results that are not original to this work.

Name, Last name $\quad$ : Eray ŞENTÜRK

Signature 


\title{
ABSTRACT \\ THE EFFECT OF SCIENCE CENTRES ON STUDENTS' ATTITUDES TOWARDS SCIENCE
}

\author{
Şentürk, Eray \\ M.S., Department of Secondary Science and Mathematics Education \\ Supervisor: Assist. Prof. Dr. Ömer Faruk Özdemir
}

September 2009, 152 pages

The purpose of the study is to investigate the effect of Middle East Technical University's Science Centre (METU SC) on students' attitudes towards science. The sample ( $\mathrm{N}=251)$ consisted of 131 males (52.2\%) and 120 females (47.8\%). The age range of the students varied from 11 to $14(\mathrm{M}=12.71, \mathrm{SD}=0.80)$. The attitude scale was administered before, immediately after, and one week after a visit to METU SC. Because of the limitations on sampling procedure two different research designs were used. Design 1 was a quasi-experimental design (46 students in experimental group, 46 students in control group) and attempted to determine the impact of METU SC on $6^{\text {th }}$ graders' attitudes towards science with respect to six constructs of the attitude scale. Design 2 was a weak experimental design $(\mathrm{N}=159)$ and attempted to determine the impact of METU SC on students' overall attitudes towards science with respect to their gender, grade levels, and science achievement scores. The results of this study suggest that METU SC has high potential on increasing middle school students' attitudes toward science in several dimensions. Furthermore, this increase is independent from gender, science achievement, and grade levels. Also considering that this achievement was 
accomplished in quite a short time (approximately one hour), science centres can be used by educators as an effective way of increasing students' attitudes toward science.

Keywords: science centres, attitude towards science, gender, grade level, science achievement 


\title{
ÖZ
}

\section{BILLIM MERKEZLERININ ÖĞRENCILERIN BILIME YÖNELIK TUTUMLARI ÜZERINE ETKISİ}

\author{
Şentürk, Eray \\ Yüksek Lisans, Orta Öğretim Fen ve Matematik Alanları Eğitimi Bölümü \\ Tez Yöneticisi: Yrd. Doç. Dr. Ömer Faruk Özdemir
}

Eylül 2009, 152 sayfa

Bu çalışmanın amacı, Orta Doğu Teknik Üniversitesi Bilim Mekrezi’nin (ODTÜ BM) öğrencilerin bilime yönelik tutumları üzerine etkisinin incelenmesidir. Örneklem (N=251) 131 erkek (\%52.2) ve 120 kız (\%47.8) öğrenciden oluşmaktadır. Öğrencilerin yaş aralığı 11-14 yaşdır (A.O=12.71, SS=0.80). Tutum ölçeği, ODTÜ BM’yi ziyaretten bir hafta önce, ziyaretten hemen sonra ve ziyaretten 1 hafta sonra uygulanmıştır. Örneklemi oluşturma sürecindeki sınırlılıklardan dolayı, 2 farklı araştırma yöntemi kullanılmıştır. Yöntem 1'de 46 öğrenci deneysel grupta, 46 öğrenci kontrol grupta olmak üzere yarı-deneysel yöntem kullanılarak, ODTÜ BM'nin 6. sınıftaki öğrencilerin tutum ölçeğinin 6 boyutuna yönelik tutumları üzerine etkisi belirlenmeye çalışılmıştır. Yöntem 2'de (N=159) zayıf deneysel yöntem kullanılarak, öğrencilerin bilime yönelik tutumları cinsiyetlerine, sınıf seviyelerine ve fen ve teknoloji dersindeki başarı puanlarına göre belirlenmeye çalışılmıştır. Araştırmanın sonucu, ODTÜ Bilim Merkezi’nin ilköğretim ikinci kademedeki öğrencilerin farklı boyutlarda bilime yönelik tutumlarını artırmada yüksek bir potansiyele sahip olduğunu gösterdi. Bununla birlikte, bu artış cinsiyetten, fen ve teknolojideki başarı puanlarından ve sınıf seviyelerinden bağımsızdır. Bu başarının yaklaşık bir saat gibi oldukça kısa bir 
sürede gerçekleştirildiği de dikkate alınırsa, bilim merkezleri öğrencilerin bilime yönelik tutumlarını artırmada etkili bir yol olarak eğitimciler tarafından kullanılabilinir.

Anahtar Kelimeler: bilim merkezleri, bilime yönelik tutum, cinsiyet, sınıf seviyesi, fen başarısı 


\section{To my friends}

who have provided selfless love and strong support during my crisis.

They have made my dream come true. 


\section{ACKNOWLEDGEMENTS}

Firstly and the foremost, I would like to express my deep appreciation to my thesis supervisor Assist. Prof. Dr. Ömer Faruk ÖZDEMIR for accepting this interesting subject and his guidance, support, and valuable encouragements throughout the study.

I would like to express my sincere gratitude to the examining committee members, Assoc. Prof. Dr. Safure BULUT, Assoc. Prof. Dr. Semra SUNGUR, and Assist. Prof. Dr. A. Kürşat ERBAŞ and Instructor Dr. Ufuk YILDIRIM.

I would like to thank Assoc. Prof. Dr. Safure BULUT, Assoc. Prof. Dr. Semra SUNGUR, Assist. Prof. Dr. Yeşim Çapa AYDIN and Dr. Tülin ACAR for their assistance.

A very special thanks goes to my beloved mother, Ayşe ŞENTÜRK. The closer I came to the completion of my goal, the more she cheered me on as she has done through all my life. I also thank to my father Şener and my older sister Şenay who always supported and encouraged me through all of my work.

Very special thanks go to incredibly valuable researchers, Senior Lecturer Dr. Janette Griffin from University of Technology Sydney, Prof. Dr. Tina Jarvis and Prof. Dr. Anthony Pell from University of Leicester for their assistance during my crisis.

I would like to thank Dr. Patrick Barmby from Durham University for his precious suggestions during the adaptation of measurement tool which is "Attitude towards Science Scale" used in the current study. 
I would like to thank my lovely older brother and sister, Atilla \& Gülgün KAYANI who always provided me with encouraging support to complete this study.

I also thank to my dear friends (Abdullah Y1lmaz, Abdurrahman Deniz, Ali Yılmaz, Emre Temel, Fatma Nur Kurt, Funda Barutçu, Gökhan Öcal, Kenan Çetin, Kerem Cantekin, Koray Şahin, Mehmet Ali Tahancalı, Masum Deniz, Mustafa Demiröz, Sahil Temel, Sedat Öztürk, Sema Topal, Sevim Sevgi, Şerafettin Altıntaş, Şerif Kaya, Dr. Tülin Acar, Umut Akın, Yener Şentürk) who always believed in me.

I thank all the participants of this study and teachers, counsellors, and administrators who helped me during data collection procedure. My special thanks go to student advisor of Mamak Oğuz Kaan elementary school, Elveda Fidan and the Trip Club's teacher of Yenimahalle Göktürk elementary school, Mehtap Kiraz for their collaboration.

I would like to thank the Rectorate of METU and the Science \& Society Centre for their support.

I would like to thank Prof. Dr. Fatoş Tünay YARMAN VURAL and Prof. Dr. Hüseyin VURAL who always supported and believed in me. 


\section{TABLE OF CONTENTS}

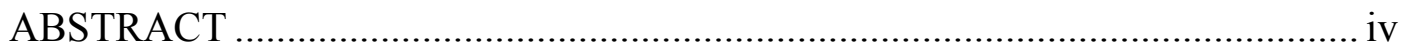

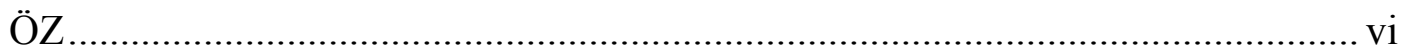

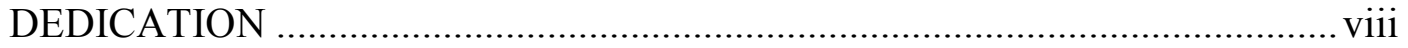

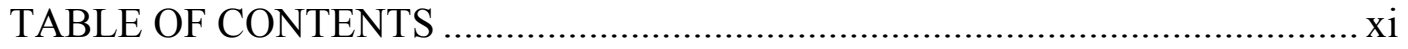

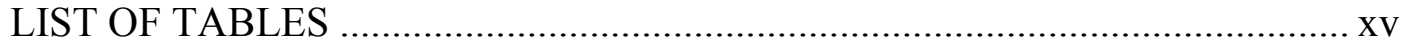

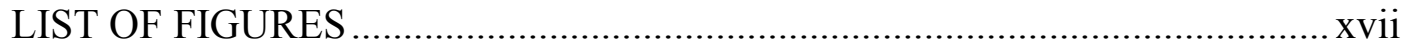

CHAPTERS

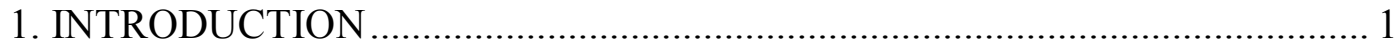

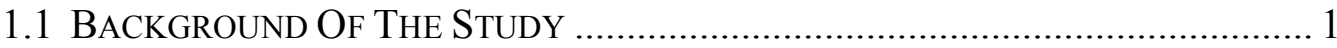

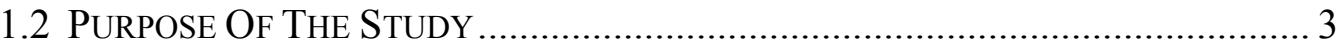

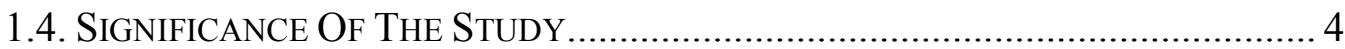

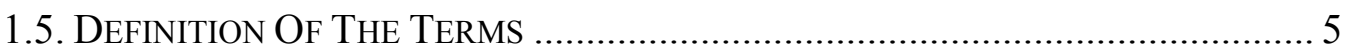

2. THE RELATED LITERATURE REVIEW …............................................ 7

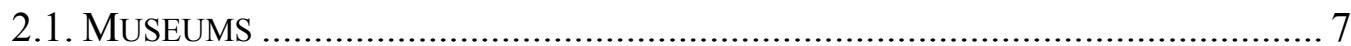

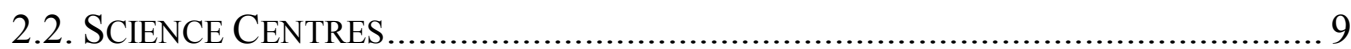

2.2.1. The Definition of Science Centre ......................................................... 10

2.2.2. Why Do We Need Science Centres? ................................................... 11

2.2.3. Researches on Science Centres ......................................................... 14

2.3. Middle East Technical University's Science Centre (METU SC) ... 24

2.3.1. From Past to Present ........................................................................... 24

2.3.2. The Goals of METU SC …............................................................. 25

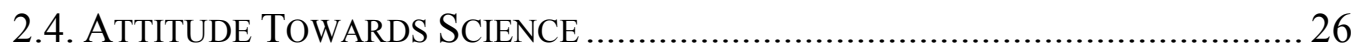

2.5. ReSEARChES ON AtTITUdE TOWARdS SCIENCE ......................................... 30

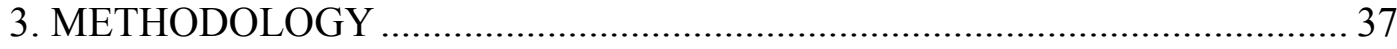

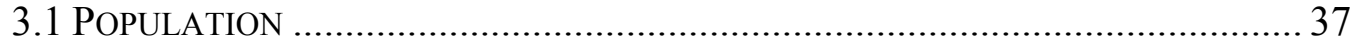

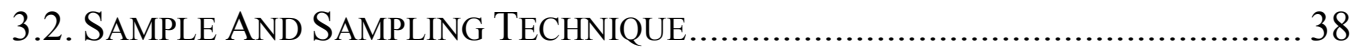




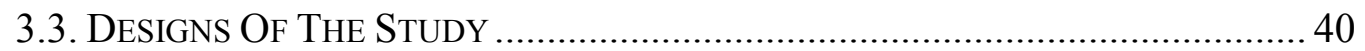

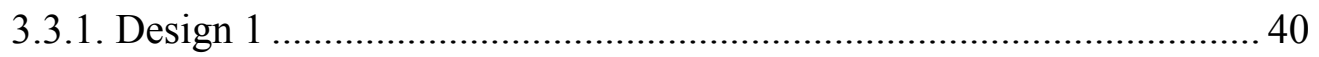

3.3.1.1. Research questions of design 1 .................................................... 41

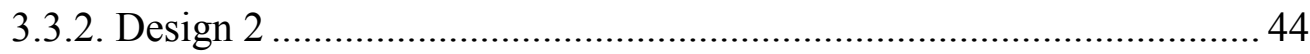

3.3.2.1. Research questions of design 2 .............................................. 44

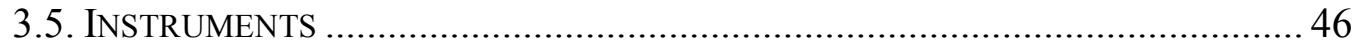

3.5.1. Information Collection Form ........................................................... 46

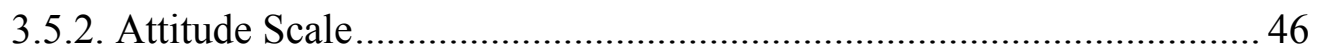

3.6. Procedures Of DATA Collection ……................................................... 49

3.6.1. First Measurement (Pretest) ............................................................ 50

3.6.2. Second Measurement (Posttest) ......................................................... 51

3.6.3. Third Measurement (Retention Test) ............................................. 53

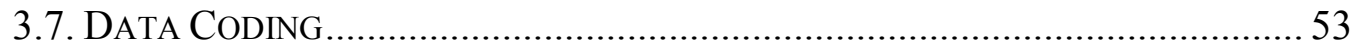

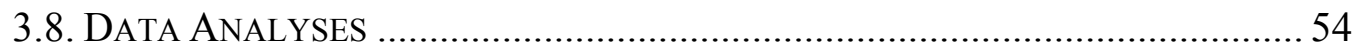

3.8.1. Mixed-Design Repeated Measures ................................................... 56

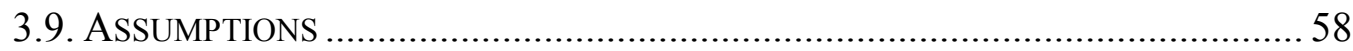

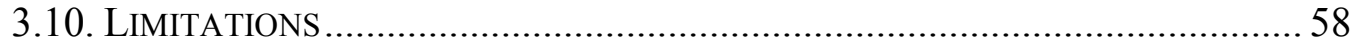

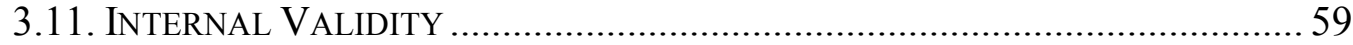

3.11.1. Internal Validity for Design 1 ........................................................59

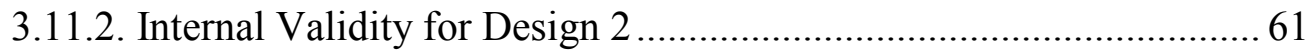

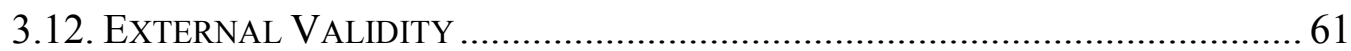

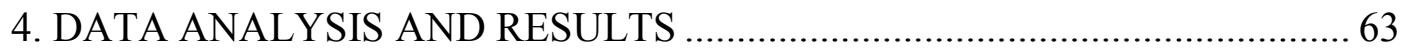

4.1. THE ANALYSIS For DESIGN 1 ….............................................................. 63

4.1.1. Main Research Question 1 ................................................................. 64

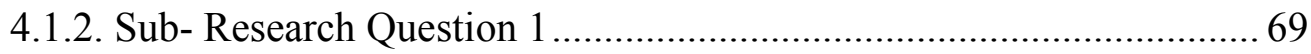

4.1.3. Sub- Research Question 2 .............................................................. 74

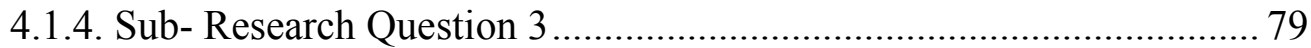

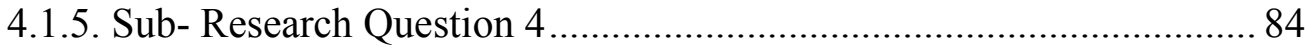

4.1.6. Sub- Research Question 5 ............................................................... 89

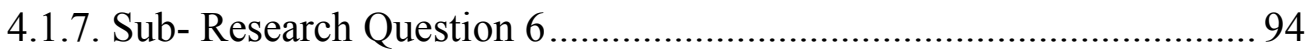




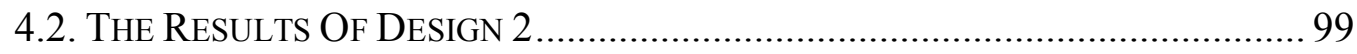

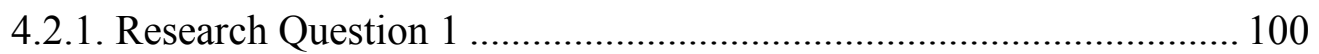

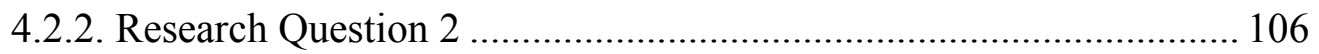

4.2.3. Research Question 3 ................................................................... 112

5. DISCUSSION, CONCLUSION, IMPLICATIONS, AND

RECOMMENDATIONS FOR FUTURE RESEARCH ….............................. 118

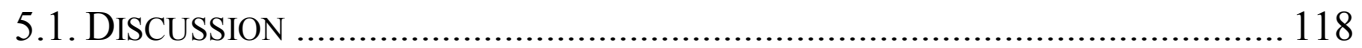

5.1.1. Attitudes Towards Science ................................................................ 118

5.1.2. Attitudes Towards Science with Respect to Constructs of the

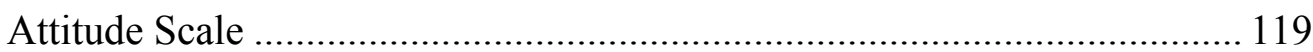

5.1.3. Attitudes Towards Science with Respect to Gender........................ 120

5.1.4. Attitudes Towards Science with Respect to Grade Levels ................ 121

5.1.5. Attitudes Towards Science with Respect to Science Achievement

Scores

5.2. CONCLUSION, IMPLiCATIONS, AND RECOMMENDATIONS For FuturE

RESEARCH

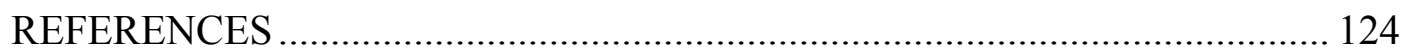

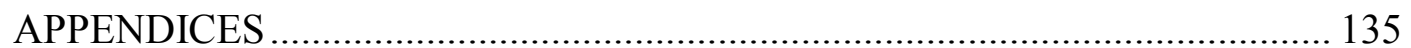

A. INFORMATION COLLECTION FORM ............................................... 135

B. ATTITUDES TOWARDS SCIENCE MEASURE ................................... 136

C. THE PERMISSION FOR THE USE OF THE ATTITUDE SCALE......... 138

D. ATTITUDES TOWARDS SCIENCE MEASURE .................................. 139

E. THE PERMISSION GIVEN BY NATIONAL MINISTRY OF EDUCATION FOR THE RESEARCH ...................................................... 142

F. VOLUNTARY PARTICIPATION FORM............................................. 143

G. PARENT'S CONSENT FORM FOR EXPERIMENTAL GROUP........... 144

H. PARENT'S CONSENT FORM FOR CONTROL GROUP ...................... 146

I. MEANS, STANDARD DEVIATIONS, ROTATED FACTOR LOADINGS, AND COMMUNALITIES FOR ATTITUDE SCALE ................................. 148 
J. EIGENVALUES, PERCENTAGES OF VARIANCE, AND

CUMULATIVE PERCENTAGES FOR FACTORS OF THE 33-ITEM

ATTITUDE SCALE ................................................................................ 150

K. EXAMINATION OF STUDENTS' CHARACTERISTICS FOR

INTERNAL VALIDITY 


\section{LIST OF TABLES}

\section{TABLES}

Table 3.1: Characteristics of Students of Mamak Oğuz Kaan Elementary School

Table 3.2: Characteristics of Students of Yenimahalle Göktürk Elementary School..... 39

Table 3.3: The Non-Equivalent Pretest-Posttest Control Group Design 40

Table 3.4: The One-Group Pretest-Posttest Design 44

Table 3.5: The Reliability Coefficients of Attitude Scale For Three Measurements 55

Table 3.6: Kmo And Bartlett's Test Results for Attitude Scale. 55

Table 4.1: Descriptive Statistics of Demographic Variables. 65

Table 4.2: Descriptive Statistics for Attitude Scores of Both Groups 65

Table 4.3: Analysis of Variance Results for Effects 66

Table 4.4: Paired T-Test Results for Experimental Group.................................. 67

Table 4.5: Paired T-Test Results for Control Group ............................................... 68

Table 4.6: Descriptive Statistics for Attitude Scores of Both Groups.................... 70

Table 4.7: Multivariate Test Result .................................................................... 71

Table 4.8: Paired T-Test Results for Experimental Group.................................. 72

Table 4.9: Paired T-Test Results for Control Group ............................................. 73

Table 4.10: Descriptive Statistics for Attitude Scores of Both Groups .................. 75

Table 4.11: Analysis of Variance Results for Effects ........................................... 76

Table 4.12: Paired T-Test Results for Experimental Group ................................. 77

Table 4.13: Paired T-Test Results for Control Group ......................................... 78

Table 4.14: Descriptive Statistics for Attitude Scores of Both Groups.................. 80

Table 4.15: Analysis of Variance Results for Effects ......................................... 81

Table 4.16: Paired T-Test Results for Experimental Group ................................ 82

Table 4.17: Paired T-Test Results for Control Group ....................................... 83 
Table 4.18: Descriptive Statistics for Attitude Scores of Both Groups 85

Table 4.19: Analysis of Variance Results for Effects ............................................. 86

Table 4.20: Paired T-Test Results for Experimental Group .................................. 87

Table 4.21: Paired T-Test Results for Control Group ......................................... 88

Table 4.22: Descriptive Statistics for Attitude Scores of Both Groups.................. 90

Table 4.23: Analysis of Variance Results for Effects .......................................... 91

Table 4.24: Paired T-Test Results for Experimental Group ................................ 92

Table 4.25: Paired T-Test Results for Control Group ........................................... 93

Table 4.26: Descriptive Statistics for Attitude Scores of Both Groups.................. 95

Table 4.27: Multivariate Test Result .................................................................... 96

Table 4.28: Paired T-Test Results for Experimental Group ................................. 97

Table 4.29: Paired T-Test Results for Control Group ........................................... 98

Table 4.30: Descriptive Statistics of Demographic Variables............................. 100

Table 4.31: Descriptive Statistics of Attitude Scores For Males And Females ... 101

Table 4.32: Analysis of Variance Results for Effects ........................................ 102

Table 4.33: Paired T-Test Results for Time ..................................................... 103

Table 4.34: Paired T-Test Results for Boys ...................................................... 103

Table 4.35: Paired T-Test Results for Girls...................................................... 104

Table 4.36: Descriptive Statistics of Attitude Scores for Grade Levels............... 107

Table 4.37: Analysis of Variance Results for Effects ........................................ 108

Table 4.38: Paired T-Test Results for $6^{\text {th }}$ Graders.............................................. 109

Table 4.39: Paired T-Test Results for $7^{\text {th }}$ Graders.............................................. 110

Table 4.40: Paired T-Test Results for $8^{\text {th }}$ Graders.............................................. 110

Table 4.41: Descriptive Statistics of Attitude Scores for Students with

Different Science Achievement Scores .......................................................... 112

Table 4.42: Analysis of Variance Results for Effects ......................................... 114

Table 4.43: Paired T-Test Results for Students with Science Achievement of

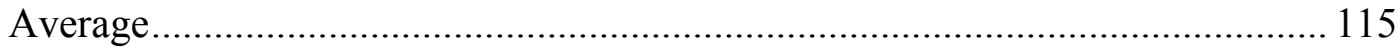

Table 4.44: Paired T-Test Results for Students with Science Achievement of Good 116

Table 4.45: Paired T-Test Results For Students With Science Achievement of Excellent 


\section{LIST OF FIGURES}

\section{FIGURES}

Figure 4.1: The Comparison of Estimated Marginal Means of Attitude Across

the Three Time Periods for Experimental and Control Group

Figure 4.2: The Comparison of Estimated Marginal Means of Attitude Towards Learning Science in School Across the Three Time Periods for Experimental and Control Group....

Figure 4.3: The Comparison of Estimated Marginal Means of Attitude Towards Self-Concept in School Science Across the Three Time Periods for Experimental and Control Group

Figure 4.4: The Comparison of Estimated Marginal Means of Attitude Towards Practical Work in School Science Across the Three Time Periods for Experimental and Control Group

Figure 4.5: The Comparison of Estimated Marginal Means of Attitude Towards Science Outside Of School Across the Three Time Periods for Experimental and Control Group....

Figure 4.6: The Comparison of Estimated Marginal Means of Attitude Towards

Future Participation in Science Across the Three Time Periods for

Experimental and Control Group

Figure 4.7: The Comparison of Estimated Marginal Means of Attitude Towards Importance of Science Across The Three Time Periods for Experimental and Control Group.

Figure 4.8: Estimated Marginal Means of Attitude over the Three Time Periods

Figure 4.9: Estimated Marginal Means of Attitude Across the Three Time Periods for Males and Females.

Figure 4.10: Estimated Marginal Means of Attitude Across the Three Time Periods for Students in Different Grade Levels.

Figure 4.11: Estimated Marginal Means of Attitude over the Three Time Periods for Students with Different Science Achievement Scores. 


\section{CHAPTER 1}

\section{INTRODUCTION}

\subsection{Background of the Study}

There is a common thought among people that science education is not necessarily for all students. However, the decline in the number of the highly qualified scientists, especially shortage of female scientists, has shown the importance of science education for all students as well as scientific literacy of societies (Jarvis \& Pell, 2002; National Research Council [NRC], 1996). Some of the goals of science education is to connect school science with students' everyday lives (Cajas, 1998); to make students benefit from the nature actively, investigate their environments, develop scientific thinking ability; and to increase the number of the scientifically literate students in society (Gezer, Köse, \& Bilen, 2007). Nonetheless, these goals are difficult and complex. Most of the teachers simply do not know how to connect school science to students' daily life experiences (Cajas, 1999; Mayoh \& Knutton, 1997). Lyons (2006) interviewed high school students to investigate their perceptions and experiences of learning science in their science classes in Australia, and he quoted the statements made by the students as follows (p.591):

This is it, this is how it is, and this is what you learn.

It is like this, learn it because it is right, there is nothing to discuss. It happened, accept it, you don't need to know this until A-level.

Unfortunately, many elementary-school graders think similar about their science and technology lessons. They find their science and technology lessons boring, and their judgement about its content is usually impractical, and hard to learn (Barmby, 
Kind, \& Jones, 2008; Ebenezer \& Zoller, 1993; House of Lords, 2000; Jenkins \& Pell, 2006; Gezer et al., 2007; Matthews, 2007; Moris, 1990; Pedretti, 2004; Sjǿberg \& Schreiner, 2005). As Pedretti (2004) pointed out, "This is not surprising as students wade through excessive content demands, usually void of context. Typically, science is presented as a corpus of knowledge to be mastered, memorized and occasionally applied to the real world." (p.40). All of these aspects influence students' attitudes negatively (Demirelli, Kavak, \& Tufan, 2006; Gezer, et al., 2007; Jarvis \& Pell, 2005), and also makes them give up pursuing the study of science in their future carrier (Osborne, Simon, \& Collins, 2003). In this respect, attitude towards science is large factor on student performance (Walker \& Rakow, 1985); it influences the students' selection of a career, and also their academic performance in middle school (Sorge, Newsom, \& Hagerty, 2000). Unfortunately, most of the students' attitudes towards science start to decrease by the age of 11 during elementary schooling, and this decline are getting more and more from this age onwards (Osborne et al., 2003). Hence, improving students' attitudes towards science is getting more and more a vital issue. Nevertheless, "the affective area is much neglected in traditional, formal science education and this neglect might well contribute to reduced uptake of the sciences, shortages of scientists and technologists in industry, and gender division, particularly in the physical sciences" (Wellington, 1990, p. 250). According to several researchers, one way of overcoming the shortcomings of formal educational settings is to support them with informal (out-of-school) settings (Bozdoğan \& Yalçın, 2006, 2009; Jarvis \& Pell, 2005; Wellington, 1990). Informal settings that provide students with experiencing real objects, developing positive attitudes, values, judgements, beliefs, and new points of views include many social places such as science centres, science and technology museums, zoos, libraries, and open-air museums (Davies, 1997; Kelly, 2000; Pedretti, 2004). The most important place of these outof-school settings is perhaps science museums/centres (Bozdoğan \& Yalçın, 2006, 2009). Science centres have crucial roles in order to improve students' lifelong interest and positive attitudes towards science (Bozdoğan \& Yalçın, 2006, 2009; 
Rix \& McSorley, 1999; Russell, 1990; Wellington, 1990). Science centres can be defined as environments providing learning by entertaining (Ramey-Gassert, Walberg, \& Walberg, 1994). Wellington (1990) pointed out that science centres include many exhibits related to science and technology that can rarely be found in school laboratories. Hence, they can make a great contribution to science education, and scientific literacy that school science may not. Several researchers also pointed out that one of the key contributions of science centres is to increase visitors' attitudes towards science (Bozdoğan \& Yalçın, 2006, 2009; Rix \& McSorley, 1999; Russell, 1990; Wellington, 1990). Even though science centres have an extremely important function for the development of students' attitudes towards science in developed countries, they are not known in Turkey, and they have not been used sufficiently (Bozdoğan \& Yalçın, 2006).

\subsection{Purpose of the Study}

The main aim of the study was to determine whether there is a potential contribution of Middle East Technical University's Science Centre (METU SC) on increasing students' attitudes towards science. More precisely, the researcher aimed to answer the following questions:

1. Is there any effect of METU SC on students' attitudes towards science?

2. Is there any effect of METU SC on students' attitudes towards science with respect to their gender?

3. Is there any effect of METU SC on students' attitudes towards science with respect to their grade levels? 
4. Is there any effect of METU SC on students' attitudes towards science with respect to their science achievement scores?

\subsection{Significance of the Study}

Science centres provide an awareness of the relevance of science to society that might me missing in class-based science learning environments (Jarvis \& Pell, 2005). Several researchers pointed out that motivation, interest, wonder, enthusiasm, and eagerness to learn which can be generated by science centres are usually ignored in traditional formal school science (Pedretti, 2002; RameyGassert et al., 1994). Wellington (1990) believed that attitude development in schools is particularly crucial due to the fact that negative attitudes may contribute to decrease in understanding of science and to the shortfall of scientists. This should be addressed during elementary schooling years because many latent scientists seemed to make decisions about their future careers in the early ages (Blatchford, 1992; Musgrove \& Batcock, 1969; Woolnough, 1990 as cited in Jarvis \& Pell, 2005). Students with positive attitudes are more likely to maintain their efforts to accomplish the given tasks (Germann, 1988). There was also positive relationship between attitudes towards science and achievement (Mattern \& Schau, 2002), and it appeared stronger for girls, pointing out that a positive attitude is more necessary for girls to enable them to obtain high scores and succeed in science (Weinburgh, 1995).

Science centres not only contribute to students' enrolment in science for future career and development of positive attitudes towards science but they can also affect achievement, consistency, and quality of work in science (Germann, 1988; Ramey-Gassert et al., 1994; Rennie \& McClafferty, 1996). However, achievement was out of scope of this study due to two reasons. First of all, increasing students' 
achievement in science at school is not one of the major aims of the METU SC. Second of all, an ordinary visit to science centre lasts approximately one hour or a little more. It is not expected from children to get a great deal of scientific information during such a short time. Science centres generally do not claim to have such a role either (Russell, 1990). They, nevertheless, have a critical role on changing visitors' attitudes towards science (Bozdoğan \& Yalçın, 2006, 2009; Rix \& McSorley, 1999; Russell, 1990; Wellington, 1990). In this respect, the investigation of the effects of science centres on students' attitudes towards science is important. However, because of the limited number of science centres, the number of studies investigating the effect of science centres on students' attitudes is very low in Turkey. Furthermore, the existing literature in Turkey does not provide a detailed picture on the effect of science centres because either attitude is considered as a unidimensional construct or the role of several factors such as gender and grade level were not considered on the effect of science centres. By extending the related literature and providing a more detailed picture on the effects of science centres on students' attitudes towards science, this study can contribute to the judgments and the decisions of science teachers, science centres' staff, ministry of national education, and science curriculum developers on the possible role of science centres as an out of school environment.

\subsection{Definition of the Terms}

Scientific literacy: "the knowledge and understanding of scientific concepts and processes required for personal decision-making, participation in civic and cultural affairs, and economic productivity" (NRC, 1996, p.22). "Being scientifically literate means not only having an understanding of a range of scientific concepts and processes but also being able to apply this understanding, together with one's own experience and values, to a range of science-related matters in private or civic life" (Henriksen \& Frǿyland, 2000, p.393). 
Science centre: a place where visitors are connected with science, given curiosity, wonder, encouragement, firsthand experience, and provided lifelong learning (The Association of Science-Technology Centres [ASTC]).

Attitude: "it is the feelings that a person has about an object, based on their beliefs about that object" (Kind, Jones, \& Barmby, 2007, p. 873).

Attitude towards science: "the feelings, beliefs and values held about an object that may be the enterprise of science, school science, and the impact of science on society or scientists themselves" (Osborne et al., 2003, p.1053).

Self-concept: "the totality of a complex, organized, and dynamic system of learned beliefs, attitudes and opinions that each person holds to be true about his or her personal existence" (Purkey, 1988 as cited in Huitt, 2004). "The self-concept is the accumulation of knowledge about the self, such as beliefs regarding personality traits, physical characteristics, abilities, values, goals, and roles" (Alvarez, 2009). 


\section{CHAPTER 2}

\section{THE RELATED LITERATURE REVIEW}

In this chapter, the review of the literature related to museums, science museums, science centres, and attitude in general and attitude towards science is presented.

\subsection{Museums}

In recent years, it has been realized that education is a long term and goal oriented process which cannot be restricted to schools settings. Like schools, libraries, historical places, martyrdoms, museums, different institutions and organizations can also become important components of education process. Especially, museums can be considered as institutions that enrich education process (Talim Terbiye Kurulu Başkanlığı, 2008a). In Turkey, the benefits of museums for education have not been taken into consideration. Furthermore, there have not been any regulations or policies towards them until recently, January 8, 2008 (Talim Terbiye Kurulu Başkanlığı, 2008b). Among others, science museums have particular importance for science education. Growing evidence suggests that the main roles of science museums are to improve students' scientific literacy by showing exhibits related to scientific concepts. They also motivate students to build their careers in science and technology domain (e.g., Henriksen \& Frǿyland, 2000; McManus, 1992). According to Ramey-Gassert et al. (1994), "Museum learning has many potential advantages: nurturing curiosity, improving motivation and 
attitudes, engaging the audience through participation and social interaction, and enrichment. By nurturing curiosity, the desire to learn can be enhanced.”(p.351). While new science museums raised and existing museums are renovated, exhibits in science museums are becoming increasingly interactive. Due to this change, science museums start to be called as science centres (Reid, 1997; Swift, 1997 cited in Botelho \& Ana, 2006). McManus (1992) proposed that science centres are distinguished from science museums in terms of interactive exhibits. In science centres, visitors pay more attention to the acquisition of scientific ideas and concepts (e.g., how the aircraft's engine works) rather than thinking of what the scientific objects are (e.g., what the aircraft's components are) or what the history of scientific developments is (e.g., how an aircraft's scientific development is). Pearce (1996) also argued that traditional museums in which exhibitions are object-oriented have "static, hands-off" displays. On the other hand, science centres in which exhibitions are based on an idea or phenomena have "dynamic, hands-on, and interactive" displays. Similarly, Semper (2007) claimed that science centres "contained collections of ideas rather than things" (p.147). Ogawa, Loomis, \& Crain (2008) also pointed out that science centres include apparatus and programs providing people with participating in the process of science rather than collections and historical objects describing traditional science museums. However, according to European Network of Science Centres and Museums' report [EXCITE] (2008), there is no significant distinction between science museums and science centres, since both exist to promote science learning. Dr. Per-Edvin Persson who is Director of Heureka, The Finnish Science Centre in Vantaa, Finland also pointed out that "The difference between a science museum and a science centre is like a line drawn in water" ( as cited in EXCITE, 2008, p. 2). Even though the terms "science centre" and "science museum" in the U.S. have the same meaning, there are still ideological argument in Germany about this issue (e.g. some people think that they are same; the others think that they are not) (Weitze, 2003). Weitze (2003) pointed out that the outlines between science 
centres and traditional science museums and other places of informal learning are blurred.

\subsection{Science Centres}

Unless the young people of the twenty-first century appreciate the importance of science, we stand no chance whatsoever of economic, social or cultural survival. In my view, science museums and science centres must play an appropriately active part in the educational program on which this survival depends. [H. Kroto, joint winner of the 1996 Nobel Prize for chemistry (1997, p.14 as cited in Jarvis \& Pell, 2002, p. 980)].

The Cold War reconstruction and the launch of Sputnik by Soviet Union in 1957 have highlighted the need of reform in science education in the United States. The beliefs that science education should be improved and that all American citizens should also have access to knowledge about science and technology outside of the schools have resulted in the development of the Exploratorium (Ogawa et al., 2008). The Exploratorium in San Francisco in USA and Ontario Science Centre in Canada both opened in 1969 were the pioneers of interactive science centres in the world. After these two science centres were opened, there has been a significant rise in the numbers of them because of the same reasons of educating public about science and technology (Ogawa et al., 2008). According to findings obtained from the $5^{\text {th }}$ Science Centre World Congress (2008) held in Ontario, Canada, more than 290 million visitors have been attracted by 2,400 science centres worldwide annually (Canadian Association of Science Centres [CASC], 2008). Particularly, there are approximately 280 science centres in Europe (The Scientific and Technological Research Council of Turkey [TÜBİTAK], 2008). Persson (1996) stated that "there are now several hundred centres in the US, 33 in the UK, 31 in Scandinavia, 12 in Spain, 10 in the Netherlands and 6 in France" (p.55). As for 
Turkey, there are a few science centres (e.g., Feza Gürsey, İstanbul Technical University, The Municipality of Şişli, Middle East Technical University Science Centre, and General Directorate of Mineral Research \& Exploration's Energy Park).

\subsubsection{The Definition of Science Centre}

Although the term, science centre, is used in this study, there are quite a number of terms used in the literature such as science and technology centres (ASTC), handson science centres (Bradburne, 1998), hands-on science and technology centres (Pompea \& Hawkins, 2002; Walton, 2000), and interactive science and technology centres (Lucas, 1983; Rennie and McClafferty, 1995). However, the researchers' descriptions and interpretations about these centres reveal that there is no significant difference among them. Janette Griffin from University of Technology, Sydney, Australia (personal communication, January, 12, 2009) states that the terms are fairly loose and there is no major difference among them.

According to ASTC, science centres can be defined as a place where visitors are connected with science, given curiosity, wonder, encouragement, and firsthand experience, and provided lifelong learning. Emphasizing the social aspect of science centres, Rennie and McClafferty (1996) proposed their definition as a social event having strong affection on behaviour and learning. Another important characteristic of science centres is that they are informal learning environments, where learning and entertainment mix together (Weitze, 2003), by allowing visitors to touch, play, and experiment with the exhibits (Quin, 1990).

Quin (1990) described the common characteristics of science centres as follows: 
- largely devoted to science and technology (including engineering and industrial processes).

- contemporary rather than historic

- interactive ('hands-on'), with specially constructed exhibits that encourage visitors to investigate natural phenomena and experiment with technology

- informal places- 'explainers', 'guides' or 'pilots' are always on hand to welcome, discuss the exhibits and help if required

- publicly and educationally oriented-the aim is to make a visit enlightening as well as entertaining. (p.243)

\subsubsection{Why do we need science centres?}

I hear and I forget. I see and I believe. I do and I understand. (Confucius)

The mission of science centres is to enhance public understanding of and attitudes toward science, and this seems vital in the $21^{\text {st }}$ century as it was in the $20^{\text {th }}$. Although activities that have been performed at science centres have been changing, the core objective of the science centres remained same as explaining scientific knowledge to non-experts and demonstrating its relevance to daily life (Persson, 2000b). Science centres can also enable people to be aware of the relevance of science to society, environment, and nature (Jarvis \& Pell, 2005). Furthermore, there are many possible contributions of science centres. First of all, they serve everybody from all ages, cultures, educational levels, and backgrounds (ASTC), and they increase people's interests in and attitudes towards science instead of giving or teaching the entire knowledge about science (TÜBİTAK, 2008). Second, they "can contribute greatly to the understanding of science and encourage students to further their interests outside of school'” (NRC, 1996, p. 45). 
Third, they provide development of skills such as effective problem solving, critical thinking, decision-making, innovation; offer people to understand how the world around them works through interactive exhibits; inspire people to think differently; and enable public to meet the complex challenges facing our world (CASC, 2008). Several researchers have highlighted the opportunities offered by science centres as the following:

\section{Science centres}

- give a chance to everyone to try experiments (Persson, 2000a; Falk \& Dierking, 1992).

- provide people to participate in experiments actively, and use all their senses (Weitze, 2003).

- make people notice effectiveness of science for a society; and improve public awareness of science (Rix and McSorley, 1999).

- provide "exploration of scientific and technological phenomena" (Quin, 1990, p. 243).

- provide students an entertaining environment less formal than a classroom (Lucas, 1983; Ramey-Gassert L., 1996).

- "can provide hands-on, exploratory science learning in a non-evaluative, relaxed context by offering science through real-world objects and natural phenomena" (Ramey-Gassert L., 1997, p.438).

- provide social interaction that was essential source of satisfaction in science centre visits and peer-teaching for students (Carlisle, 1995 as cited in Rennie \& McClafferty, 1995).

- provide teachers to discover the interactive presentation techniques presented in science centres (Lucas, 1983).

- promote interest and curiosity, and make people notice how the world works (Russell, 1990). 
- make a great deal of contributions to the affective domain of the students which includes generating wonder, enthusiasm, excitement, motivation, interest, awareness, and attitudes that affect their learning (Gammon, 2007; Rennie \& McClafferty, 1995; Wellington, 1990).

Nowadays, science centres attract wide variety of visitors from five to eighty years old (e.g., children, students, adults, families, and teachers individually or in groups) (Walton, 2000). While some visitors evaluate the science centres as an educational place; some others consider it as a place where they spend their leisure time (Lucas, 1983). Besides, some visitors come to science centres because of the fact that they want to refresh their scientific knowledge about basic scientific concepts and principles (Persson, 2000a).

400 leaders from 51 countries participated in $5^{\text {th }}$ Science Centre World Congress held in Toronto, Ontario, Canada agreed that (CASC, 2008):

Children who attend science centres are growing up in a rapidly changing world and can become critical "agents of change" so that everyone can have a better future. Teens and university students who participate in science centre programs are tomorrow's leaders and decision makers. Adults who visit our centres and get involved re-engage with science and become better positioned to understand the context of scientific discoveries and contribute to dialogue on topics such as climate change, human health, the need for renewable energies, water shortages and HIVIAIDS. We, the participants in the Fifth Science Centre World Congress, believe that science is an important tool for better life on our planet. We commit to work together to overcome cultural, physical,social, economic and geographic barriers to engage and connect people through science (p.6). 


\subsubsection{Researches on Science Centres}

Based on 180 reports from science centre networks which are ASTC, ECSITE, ASTEN and ASPAC ${ }^{1}$ Garnett (2002) classified the studies inquiring about the impact of science centres. According to this summary, $87 \%$ of the reports focused on "personal impact" such as individual's science learning, changes in attitudes towards science, enjoyment, and career choice. Most of the studies (54\%) were related to science learning in science centres. One-quarter of the studies investigated the impact of science centres on changing attitudes towards science $(18 \%)$ and enjoyment of visitors (7\%). Other studies were associated with the impact of science centres on career choice and professional developments of teachers. The results of these studies showed that science centres have a positive impact on a number of areas. Besides, the impact of science centres on other areas has also been reported in the literature. For instance, Pompea and Hawkins (2002) highlighted the importance of science centres/museums in promoting visitors' scientific literacy in optics and photonics. They also highlighted the importance of the use of webs about some particular events offered by science centres/museums. Especially they pointed out the web-based event created by the Exploratorium in San Francisco about total solar eclipse in Zambia taking place on June 21, 2001. They reported that the "Live from Africa" solar eclipse event was a great educational accomplishments and 42.000 people participated in this event at museums and science centres all over the world. They concluded that science

${ }^{1}$ ASTC : The Association of Science-Technology Centres

EXCITE : The European Network of Science Centres and Museums

ASTEN : The Australasian Science and Technology Exhibitors Network

ASPAC : The Asia Pacific Network of Science and Technology Centres 
centres/museums have a great deal of contributions to increase publics' interest in science as well as publics' understanding of science.

Morris Hargreaves McIntyre Consultancy and Research organization (2005) outlined that there are many possible social outcomes as a result of museum visit. Over 8000 interviews with the visitors were carried out and 4000 visitor observations were made at over twenty five museums and galleries across the United Kingdom. The results showed that museums and galleries have many potential outcomes that are social in nature, such as social interaction, entertainment, inclusion, access, and comfort. The results also showed that the visitors can gain intellectual, aesthetic, and spiritual outcomes.

However, the majority of researches in science centres have focused on cognitive gains especially conceptual understanding, and most of them reported at least short-term increases (over weeks or months) on visitors' conceptual understanding. For instance, Anderson, Lucas, Ginns, and Dierking (2000) explored the effect of various interactive exhibits on students' understanding of the principles underlying electricity and magnetism. They found that students, aged 11-12 years, did not passively accept the science concepts and principles related to electricity and magnetism represented in science museum. In contrast, they constructed their own models by actively interpreting what was experienced in the science museum and incorporating them into their existing mental models. Similarly, Beiers and McRobbie (1992) found evidence for the impact of various interactive exhibits on $277^{\text {th }}$ graders' understanding of the scientific principles underlying the sound concept. Allen (2002) explored whether or not visitors learn while visiting an exhibition at Exploratorium in San Francisco throughout twenty days. She focused on the Frogs exhibition and her sample consisted of 49 visitor pairs including adults and children. She recorded visitors' conversations at the exhibition. Visitors spent an average of 25.4 minutes in the Frogs exhibition. She found that visitors engaged in some types of learning-talks occurring at $83 \%$ of the exhibits and 
representing $97 \%$ of all the conversations recorded, and specifically $56 \%$ of these talks were found to be conceptual-talks. Specifically, Stevenson (1994) found that 'Launch pad $^{2,}$ visitors' concentrations were almost never distracted after 60 minutes which is very important because in a normal museum visit, visitors display disorganization of attention after 30 minutes. Rennie and McClafferty (1996) evaluated these findings and raised some questions: Have visitors really concentrated or were they just having fun? While responding to these questions some researchers used the term "edutainment" to describe science centres. Rennie and McClafferty (1996) stated that "entertainment aspect is more successful than educational one" (p.55). Similarly, Shortland (1987) criticized the science centres by stating that "when education and entertainment are brought under the same roof, education seems to be the loser" (p.213). Contrary to Shortland (1987), Wellington (1990) claimed that children do not just play and entertain at science centres, they can also learn. In order to prove that, he produced a video in the summer of 1989 entitled "Hands-on science: It's fun but do they learn?" The purpose of the video was to examine different perspectives on the centres by filming visitors in action and by interviewing a wide range of children, teachers, guides, parents and other adult visitors. He interviewed every teacher (unspecified number) in his study. The interviews demonstrated that science centres make some contributions to pupils' science education. He also argued that playing and entertaining do not seem to be drawbacks; on the contrary, they are seen as advantages resulting in educating the scientists of the future. Moreover, he

\footnotetext{
2 'Launch pad' is the most popular hands-on, brains-on gallery in third floor of London science museum. It includes over 50 interactive exhibits demonstrating the wonderful world of physics.

${ }^{3}$ It can be defined as a mixture of education and entertainment.
} 
highlighted that science centres make contributions to the development of motivation and interest in science and technology which cannot be underestimated.

School field trips to science centres also have a measurable impact on young children. Hooper-Greenhill, Dodd, Gibson, Phillips, Jones, and Sullivian (2005) conducted a very large-scale study including 26.791 (50\% female, 47\% male, 3\% missing) children from primary and secondary level and 1.643 teachers visiting 69 science museums across England during September, October and November 2005. 1.594 school visits were made to the 69 museums. Approximately $81 \%$ of the visits were made by primary schools, and approximately $10 \%$ of the visits were made by secondary schools. Specifically, $38 \%$ of the schools were from socially deprived areas where students are provided free school meal. The use of museums for curriculum-related purposes is more pronounced for primary teachers than secondary teachers. The primary teachers claimed that museums are very important to their teaching. Both teachers and students were tremendously satisfied about their museum visit, highly enthusiastic and confident about using the museums in the future. Teachers claimed that their pupils obtained many educational gains. The museums enable pupils to promote the acquisition of new knowledge, understanding, and the development of attitudes, values, and inspirations. About $93 \%$ of teachers thought that their students enjoyed the museum visit; were excited by new ways to learn, inspired to learn more; increased their interests; felt more positive about their learning. About $87 \%$ of teachers anticipated an improvement in their students' thinking, communication, and social skills. About $88 \%$ of students learned some new knowledge; $83 \%$ thought museums are good places to learn in a different way than schools; $71 \%$ thought museum visit provide a better understanding; $68 \%$ thought museum makes school work more inspiring. The students' positive responses from socially deprived areas were extremely impressive. This indicated that museums seemed to have more potential to be effective in working with students from socially deprived areas. 
A follow-up study was conducted by Watson, Dodd, and Jones (2007) on behalf of Research Centre for Museums and Galleries (RCMG) in the Department of Museum Studies at the University of Leicester. They investigated the impact of museum visits on the attainment of secondary school students. 762 secondary school students from nine schools visiting five museums and one archive in the East of England region participated in this study during 2006-2007. Students' attainments were measured through teachers' assessments and teachers' judgements about the nature of their progression before and after the visit. Nine schools provided marks for 762 students for the museum-related assignment and up to three previous assignment marks with which the museum-based assignment could be compared. Most of the schools analysed the marks they sent and the teachers provided the evidence of pupil progression; whether they thought the pupil went up, stayed the same, or went down in their marks for their museumbased assignment. A further 451 students (and 11 teachers) completed questionnaires about their learning experiences at the end of their museum visit. The results showed that $60 \%$ of the students achieved a higher mark for museumbased assignment, $27 \%$ of students stayed the same and $13 \%$ of pupils went down in their marks when compared to up to three previous assignments. $51 \%$ of 'higher ability', $55 \%$ of 'average ability' and $71 \%$ 'lower ability' students increased their marks on their museum-based assignment. Furthermore, the researchers found that students and teachers were positive about their learning in museums. $90 \%$ of students agreed that the museum was a good place to learn in a different way to school. Both boys and girls were enthusiastic about their museum visits and confident about their learning. There was no gender difference. Both boys and girls were influenced equally by museum learning. The researchers concluded that museums can have a positive impact on secondary students' learning and attainment; motivate students across a range of abilities; can help schools tackle difficult areas of the curriculum and assessment; and provide different models of engagement for schools. The relationship between the school and the museum was 
important and the role of experienced learning or education staff in the museum was a critical factor in ensuring the success of the visit.

However, the researchers have not only focused on the impact of science centres on students' cognitive learning but they also have focused on affective learning referring to the generation of strong emotions and the change of visitors' attitudes. For example, Russell (1990) highlighted the importance of science centres on visitors' attitudes in his study entitled "Visiting a science centre: What's on offer?" He also highlighted the importance of some issues (e.g., exhibit design, exhibit labels, visitors' background knowledge, and objectives of science centres, adults and teachers). He pointed out that science centres are effective in affective learning (changing attitudes) rather than cognitive learning (knowledge and understanding) and proposed that teachers and adults should help children benefit from the museum visit. They should not explain everything because of the fact that explanations are the quickest way to stop children thinking for themselves. They should promote questions that encourage children to think independently.

In a similar way, Salmi (2003) explored the effect of Heureka, Finnish Science Centre located in Vantaa, Finland, on students' motivation to learn science. The result suggested that students' situational motivation could be changed to intrinsic motivation by means of well organized programs linking schools to the informal, open learning environments of science centres. Besides, a survey taken among 1.019 first and second year Helsinki university students verified that informal learning sources such as science centres have a strong impact on their academic career choices. Correspondingly, according to an online survey conducted for Canada by The Strategic Counsel in 2008, more than $90 \%$ of Canadian university students said that visits to science centres increased their interest in science and technology (CASC, 2008). Similarly, Rix and McSorley (1999) explored the effect of science centre-types activities on students' attitudes towards science. They selected school's TV room for their research and furnished it with exhibits 
designed to imitate those found within interactive science centres. They explored how science centre-type activities could be incorporated into schools and whether it would be possible for schools to create their own interactive science centres/activities for use in the classroom. Finally, they set up a mini-museum including seven interactive exhibits in TV room. They found that mini-museum help children develop positive attitudes towards science. However, they pointed out that improvement might only be a temporary effect due to the fact that the children's attitudes towards science were assessed immediately after their visits to the mini-museum. They proposed that interactive science centres should be considered as a useful resource in the development of children's science education.

The long-term impact of science centres on students' attitudes towards science has also reported in the literature. For instance, Jarvis and Pell (2002) explored the impact of Challenger Space Centre ${ }^{4}$ experience on elementary students' general attitudes towards science and space through 5 months after their visit by examining their responses to the attitude scale. Their sample consisted of 655 students from Year 6, aged 10-11 years, in 23 schools in the city of Leicester, UK. All the schools participated in the study were from socially deprived areas. The children had limited or no experience of visits to any science centre due to the fact that schools are unable to raise sufficient funds. The attitude scale consisted of 38 items constituting five sub-scales that are 'science enthusiasm', 'science in a social context', 'space', and 'planning and teamwork' and 'working confidence'. The attitude scale was administered to the students immediately before and after the

\footnotetext{
4 “The Challenger Learning Centre is a part of National Space Centre in Leicester, United Kingdom and is a non-profit organization. It is the only educational space mission simulator of its type outside of North America. It was founded by the families of the astronauts lost during the last flight of the Challenger Space Shuttle in 1986. Using space exploration as a theme, Challenger Centre creates positive learning experiences that raise students' expectations of success; foster a long-term interest in mathematics, science, and technology; and motivate them to pursue careers in these fields. They have been specifically adapted by the University of Leicester to fit the requirements of the National Curriculum."
} 
Challenger experience as well as two and five months later. Knowledge tests were also administered before and after the visit. For the follow-up measurement after 2 and 5 months, the sample was split into two because of the fact that Year 6 students are faced with national test at this time of the year in England. Therefore, the researchers asked the sample of students (randomly selected) to complete the anxiety test in order to minimize the testing load on the students. Their results showed that all students did not increase their knowledge test scores from the pretest to post-test: $68 \%$ of students raised their scores on the post-test whereas $32 \%$ of them fell back. There were also differences between boys and girls. Some $24 \%$ of students, mostly girls, were inspired to become scientists, and this change was sustained for several months. Besides, these students became more positive about pursuing the study of science in their future careers. These students also depicted a significant increase in their science enthusiasm and an appreciation of its social context. Students who already disposed to be scientists were less affected by the Challenger experience and there was a significant negative effect on a small group of anxious girls. There was also less fear of space travel with a greater appreciation of the use of science to protect the planet after the visit. This indicates that it is important to emphasize this aspect of the visit to the girls, because girls were more interested in science when it is presented in a social context and because the Challenger experience appears to have better outcomes with students who already appreciate the social context of science. They also highlighted the importance of science centres because of the fact that a quarter of the students increased their future career aspirations to become scientists in such a 2- to 3-hour experience. However, they suggested that improvements might be because of careful pre-visit preparation during the simulation. In short, this study showed that science centres can have lasting impact upon students' attitudes towards science and their science enthusiasm.

In the same way, Jarvis and Pell (2005) explored attitude changes of 300 children, aged 10-11 years, from four schools, who visited the National Space Centre in 
Leicester, United Kingdom. Attitudes towards science and space were investigated by examining students' responses to five different scales that are 'science enthusiasm scale', 'science in a social context scale', 'space interest scale', 'working confidence scale', and 'anxiety scale'. These scales were administered to students one month before, immediately after, two months and four-five months after a visit to the main exhibition area and Challenger Centre. The classes were observed during their visit, and interviews with teachers and a group of children were completed. The results showed that there was an increase in attitudes with regard to science enthusiasm and space interest immediately after the visit, even though this was not statistically significant for science enthusiasm. Students who were already interested in science did not show a significant change in their science enthusiasm; however, their science enthusiasm remained high over five months. Students who were not interested in science depicted significant increase in their level of interest that maintained over five months. However, the majority of students ( $62 \%$ boys and $71 \%$ girls) did not demonstrate long-term gain. Even though there was a positive impact of visit to science centre on students' attitudes towards science and science enthusiasm at the beginning, in-depth interviews with students revealed that this positive impact was undermined by negative school experiences at a later time. There was also increase in attitudes towards science in a social context after the visit that stayed at a high level. Nearly, $20 \%$ of students depicted a raised desire to become scientists in the future. Two months later, these students (mostly girls) continued to be more positive about being future scientists. The researchers also found that teachers' preparation, personal interest, and their supports provided for students during the visit have a significant long term effect on pupil's attitudes. This study showed that science centres can have lasting impact upon students' attitudes towards science and their science enthusiasm.

Unfortunately, the number of studies related to science centres in Turkey is very limited. Bozdoğan \& Yalçın (2006) explored the impact of science centres on primary education students' interest and achievement in science. Their random 
sample consisted of twenty seven $6^{\text {th }}$ graders and nineteen $7^{\text {th }}$ graders. They conducted their study in the General Directorate of Mineral Research \& Exploration's Energy Park in Ankara, Turkey during December, 2005. They used two scales developed by them that are "interest scale" and "academic achievement test" and one group pretest-posttest design. They found that the Energy Park is effective in increasing the interest and achievement in science of students at the second level of primary education. Their result also showed that there is no significant relationship between students' interest and achievement in science.

In a more recent study, Bozdoğan \& Yalçın (2009) explored the positive impact of Feza Gürsey science centre (FGBM) in Ankara, Turkey on $8^{\text {th }}$ graders' interests and academic achievements in science. They used "interest scale" and "academic achievement test" developed by them. They carried out their study in 2005 . Their results showed that FGBM is effective in increasing $8^{\text {th }}$ graders' interests and academic achievements in science. They also reported that there is no significant relationship between $8^{\text {th }}$ graders' interest and academic achievement in science.

Collectively, studies from the literature showed that there is significant evidence that science centres/museums have many potential contributions. They increase visitors' knowledge, scientific literacy and understanding of science, and that they provide people with valuable motivational opportunities affecting their behaviour and learning. Affective learning is significant and science centres/museums indicated that they have a strong impact on their visitors' attitudes in positive way and this impact can be long-term. 


\subsection{Middle East Technical University's Science Centre (METU SC)}

This section presents the development of METU SC and its goals.

\subsubsection{From past to present}

METU SC came into existence around 2005 and served as a part of Science and Society Centre. Science and Society Centre has one chief, 8 administrative board members, 4 research assistants, 3 technical staff, and one staff who is responsible for the economical issues. Specifically, today two research assistants are responsible for the METU SC. At first, METU SC performed its activities in a small building. In 2007, a new building called Unidentified Flying Object (UFO) was constructed. It is supported by State Planning Organization (SPO), and Rectorate of METU. It is one of the most popular science centres in Turkey and it has been successful in attracting approximately 40.000 visitors per year. It serves everybody from all ages, cultures, educational levels and backgrounds. In addition, elementary, secondary, and high schools, not only from Ankara but also from the other cities, can benefit from the centre for free. Schools can also visit the METU $\mathrm{SC}$ in groups. However, in order to visit in groups, schools should make an appointment with METU SC. When school groups come to the METU SC, they are given a presentation including the introduction of METU and METU SC and the explanations of 12 exhibits which is called "science show". The presentation lasts approximately 40-50 minutes. After the presentation, students are released and accompanied by guidance in order that they can make their own experiments. Furthermore, METU SC enable visitors to use "pick and choose" option; if an exhibit does not interest them, then they can freely move on to another. Today, METU SC presents 106 interactive exhibits. Most of them are related to physics; a few of them are related to biology and mathematics. Two research assistants 
working at Science Centre have been carrying out the development and optimization of these exhibits. The exhibits were classified with respect to the underlying scientific concepts such as electricity, magnetism, optics, and waves. This classification eases understanding of the scientific concepts. According to METU SC, each of the exhibits in the motion floor (one of the floors in the centre) can be rotated, waved, "pushed, pulled, pressed, or prodded into action" to investigate science concepts (Stringer and Ward, 1995, p.2 as cited in Rix \& McSorley, 1999). This centre exhibits the relevance of science to daily life. For instance, Bernoulli blower allows visitors to feel and see air pressure, its effects and its uses in daily life. Basically, workshops, activities, science shows on stage conducted by accompanied guides constitute the essence of METU SC's programs. Besides, METU SC generates mobile exhibits that are sent out to school halls, local community centres, other science centres, and shopping malls. Furthermore, in "Access to society" projects conducted by METU SC, twenty five interactive exhibits are taken to the poor regions of Turkey where you may not find any science laboratories and science centres.

\subsubsection{The goals of METU SC}

Many studies indicated that most of the students have negative image of science or negative attitudes towards science. For instance, House of Lords (2000) found that students are generally bored at science lessons in school. Teachers are also bored because of the difficulties in teaching science. One of the major goal of METU SC is to contribute to make students' develop positive attitudes towards science. The other goal of METU SC is to connect science to everyday life experiences. In addition, there are many goals of METU SC as the following (ODTÜ): 
1. To do researches in order to increase the level of scientific awareness in society.

2. To rise society's interest towards scientific and technological subjects.

3. To make society like science and increase the use of science in daily life.

4. To make people notice the developments in science and technology.

5. To supplement science education in schools.

6. To arrange activities through which people can conduct science experiments.

7. To constitute suitable opportunities for students to gain experiences about scientific subjects.

8. To corporate with national and international institutions to increase the awareness of public on scientific issues.

9. To improve national and international projects related to science education.

\subsection{Attitude towards Science}

During the globalization process, many countries have been competing with each other -in different subject domains, especially in science and technology, and this competence put science education in the limelight. Osborne et al. (2003) pointed out the decrease in the number of students planning to pursue studying science in the future, and they emphasized that this situation should be investigated immediately in depth for nations' future economic prosperity. For this reason, the governments all over the world took some actions in order to increase people's interest in science. This situation caused researchers to investigate attitudes towards science. An immense body of literature accumulated throughout the decades reveals that attitude consists of three components which are cognitive, affective, and behavioural. These components were explained by Reid (2006, p.4) as the following: 
1. "A knowledge about the object, the beliefs, ideas component (Cognitive)"

2. "A feeling about the object, like or dislike component (Affective)"

3. "A tendency towards action, the objective component (Behavioural).”

In fact, this is a reasonable view of attitude because of the fact that the three components complement each other. If we have knowledge about something, we have a feeling about it, and for this reason we take some actions (Kind et al., 2007). However, some researchers suggested that these components should be discussed independently, and the attitudes should be viewed as "evaluative judgements" (Ajzen \& Fishbein, 2000; Azjen, 2001; Crano \& Prislin, 2006). Ajzen and Fishbein (2000) proposed to use the term 'attitude' as a reference to the evaluation of an object. Kind et al. (2007) proposed that when an individual has an attitude, s/he judges something in affective dimensions (e.g., science is beneficial or harmful; important or unimportant; likable or dislikeable). His or her evaluative judgements are always towards something which is called "attitude object" (Crano \& Prislin, 2006). It is recognized that these evaluative judgements defined as attitude towards something differs from the well-known definition of attitude as "affect" which are general moods (happiness or sadness) and specific emotions (fear, anger, envy) (Ajzen \& Fishbein, 2000). Even though Ajzen and Fishbein (2000) draw a clear distinction between the "attitude" and "affect", they proposed that attitudes may be influenced by moods and emotions (e.g., fear of flying may bring about a negative evaluation of airplanes). Besides, they emphasized that attitudes are related to beliefs that individual holds (e.g., science and technology lesson is beneficial or difficult subject). Furthermore, they stated that "in Fishbein's theory, people's evaluations of, or attitudes toward, an object are determined by their accessible beliefs about the object, where a belief is defined as the subjective probability that the object has a certain attribute" (Fishbein \& Ajzen, 
1975 as cited in Ajzen \& Fishbein, 2000, p. 4). The terms "object" and "attribute" refer to distinguishable aspects of a person's world. For instance, an individual may believe that studying harder (attitude object) reduces the risk of failure (the attribute). In this respect, the cognitive and affective dimensions of attitude affect each other reciprocally in an ongoing process, which in the end gives rise to behaviour (Nieswandt, 2005). Kind et al. (2007) defined the attitude as "it is the feelings that a person has about an object, based on their beliefs about that object" (p. 873). Briefly, cognitive dimension of attitude includes individual's beliefs about an object (e.g., I believe that my science and technology lesson is beneficial/ difficult). Affective dimension includes the feelings that individual has about an object based on his/her beliefs (e.g., I like/hate/love my science and technology lesson). Behavioural dimension of attitude includes individual's actions (e.g., individual's swinging from science lesson, individual's participation in all science lessons, individual's works towards this lesson as individually in his/her leisure time or not etc. (Yılmaz, Yalvaç, \& Tekkaya, 1998). As for "attitude towards science", its definition is still nebulous and not well understood (Osborne et al., 2003). However, Osborne et al. (2003) stated the definition of attitude towards science that "the feelings, beliefs and values held about an object that may be the enterprise of science, school science, and the impact of science on society or scientists themselves" (p.1053). Kind et al. (2007) defined attitude towards science as "cognitive and emotional opinions about various aspects of science" (p.873). They identified attitudes towards science as a subset of various categories including "self-concept in science", "learning science in school”, "practical work in science", "science outside of school", "importance of science", "future participation in science".

The measurement of "attitude" has still been discussed by most of the researchers. Osborne et al. (2003) determined that the most commonly used measurement type for attitude was questionnaires consisting of Likert-type scale items. However, 
they described many other types of measurements of attitude as the following (pp. 1055-1059):

1. Subject preference studies: attitude is measured by asking students to rank their liking of school subjects

2. Attitude scales: attitude is measured by means of questionnaires consisting of Likert-type scale items with a five point response

3. Interest Inventories: attitude is measured by asking students to select the items that they are interested in from a given list.

4. Subject Enrolment: attitude is measured by gathering data on enrolment in various subjects.

5. Qualitative methodologies: attitude is measured by interviewing with students in-depth.

What factors influence students' attitudes towards science? Osborne et al. (2003) response to this question, generated by reviewing the literature, is gender, personality, structural variables (e.g., classroom/teacher factors), and curriculum variables (e.g., perceived difficulty of science). However, literature suggest that there are many other factors affecting students' attitudes towards science such as grade levels, science achievements, socioeconomic status, self-concept in science, science experiences at outside of school, peer and parental support, and parents' perceptions of and attitudes towards science. The following section presents the studies on attitudes towards science. 


\subsection{Researches on Attitude towards Science}

Most of the studies in the literature have focused on the relations between the attitudes towards science and gender. For instance, Baker and Leary (1995) investigated the girls' attitude toward science. Their sample consisted of 40 girls in grades $2,5,8$, and 11 . They used semi-structured interview model. They interviewed with students in depth in order to determine their feelings about science, and how they learned science. The researchers also requested students to respond to questions as if they were boys in order to determine whether students' responses were based on gender. They found that girls had high self-confidence, and they were positive about science. All of them claimed that girls can and should do science. They also reported that they liked learning science in the interactive social context rather than participating activities that isolated them (e.g., independent writing, reading or note-taking).

Similarly, Jones, Howe, and Rua (2000) explored $6^{\text {th }}$ grade students' attitudes and experiences related to science with respect to their gender. Their sample consisted of 437 students (51\% male, 49\% female) from five schools located in rural, urban, and suburban communities located near large cities in the south-eastern United States. The students completed a survey designed to elicit their perceptions of science and scientists, out-of-school science experiences, science topics of interest, and characteristics of future jobs. The survey was developed by Sjǿberg, Mehta, and Mulemwa (1995), and it included seven factors which are "Scientists as Persons", “Out-of-School Experiences”, “Things to Learn About” (interests), "Importance for Future Job" (future job characteristics), "Science in Action" (perceptions of science), "Scientists at Work", and "Me as a Scientist". The researchers found that there were significant gender differences in science experiences, attitudes, and perceptions of science courses and careers. First of all, they found that while male students reported more experiences in physical sciences, female students reported more experiences in biological sciences in their 
out-of-school experience. Secondly, they found that while male students were more interested in physical sciences, female students were more interested in biological sciences. Thirdly, they found that while male students wanted to do in their future career 'control other people', 'become famous', 'earn lots of money', and have a simple and easy job, female students wanted to 'help other people' in their future careers. Students' perceptions of science were also significantly different from each other. Male students reported that science was destructive, dangerous, as well as more suitable for boys. Female students reported that science was difficult subject to understand.

Relations among attitudes toward science, grade levels, and gender were also examined. For instance, George (2000) examined the change in students' attitudes towards science over the middle and high school years. The sample consisted of 444 students. The students were selected from the middle and high schools (from 7 th grade to 11 th grade). The results showed that there was a sharp decline in attitudes towards science over the middle and high school years, and boys have had higher attitudes towards science than girls. However, their attitudes towards science declined faster than girls. Furthermore, the result showed that self-concept in science was the strongest predictor of attitudes towards science. Teacher encouragement and peer attitudes were also significant predictors of attitudes towards science. With the same sample, George (2006) explored students' attitudes towards science and attitudes about the utility of science. The results revealed that boys start off with more positive attitudes than girls, but boys' attitudes decline faster than girls. The results also showed that while students' attitudes about the utility of science were positive in overall, their attitudes towards science decreased over the middle and high school years.

In quite an extensive study, Francis and Greer (1999) explored different graders' attitudes towards science. Their sample consisted of 2129 (1174 males, 955 females) students; 556 third graders, 491 fourth graders, 537 fifth graders, and 545 
sixth graders. They used a scale consisting of 20 items about attitudes towards science developed by them. They found that boys have more positive attitudes towards science than girls, and they also found that younger pupils have more positive attitudes toward science than older pupils.

In a more recent study, Barmby, Kind, and Jones (2008) investigated the variation of attitudes towards science over the first three years of secondary schooling with gender. They used one attitude questionnaire consisting of 37 items incorporating the measures of the following areas: "Learning science in school" (6 items), "Practical work in science" (8 items), "Science outside of school" (6 items), "Importance of science" (5 items), "Self-concept in science" (7 items), and "Future participation in science" (5 items). Their study was carried out in England, and their sample consisted of 932 pupils (272 Year 7, 432 Year 8, and 228 Year 9 pupils) with the age of 11-14 years from five different schools (three of them located in the North East of England, one in the South East of England, and one in the South West of England). They found a steady decline in attitudes towards science while students progresses through school, and this decline was more pronounced for female pupils. Furthermore, they found that the problem emerged from pupils' experience about science in school setting. Many pupils perceived their school science as irrelevant, boring, and impractical. By considering these results, they recommended that the researchers need to concentrate on improving pupils' experiences of science in school.

Students' attitudes towards physics as well as science were also explored. Coughlan (2000) summarized the reports presented in the European Union Physics Colloquium on Attainment in Physics in which many European countries participated. A major issue of concern in many European countries such as Denmark, England, Wales, Finland, France, Greece, Ireland, Netherlands, Scotland, and Northern Ireland is the decrease in the number of students taking physics. Furthermore, the reports pointed out the decline in interest in science 
among students aged 11-14. The reports depicted that boys significantly took more physics course than girls at senior second level (4:1 in England, 1.5:1 in Finland). Correspondingly, Reid (2003) explored Scottish students' attitudes towards science and physics with regard to their gender with the age range of 10-18 years. The results revealed that the attitudes towards science for girls and boys were positive at the end of the primary school. However, these positive attitudes for both boys and girls decreased at the end of the second year of secondary school, and this decline was significant for girls. Surprisingly, most of the students $\left(4^{\text {th }}\right.$ year in secondary school) wanted to continue studies in physics. However, their attitudes towards physics, especially for boys decreased during a higher grade course (a 1year course which follows secondary school).

Students' attitudes towards their science and technology lesson were explored. Çakır, Şenler, and Taşkın (2007) investigated students' attitudes towards their science and technology lesson with regard to some variables such as gender, grade level, and self-concept in science. Their sample consisted of 440 students at second level of primary schools in Muğla, Turkey. They found that $6^{\text {th }}$ graders had more positive attitudes towards science and technology lesson than $7^{\text {th }}$ and $8^{\text {th }}$ graders. The students' grade levels were inversely proportional with their attitudes towards science and technology lesson. By the increase of grade level, students' attitudes decreased. They found no gender differences in attitude towards science and technology lesson. They also found that students' self-concept in science were directly proportional with their attitudes.

In a similar study, Gezer et al. (2007) conducted a research about students' attitudes towards their science and technology lesson with respect to gender. Their sample consisted of $2926^{\text {th }}$ graders in six different schools in Buldan district, Denizli, Turkey and the study was conducted during the fall semester of 2006/2007 academic year. They found gender differences in attitudes towards science and 
technology lesson; girls had more positive attitudes towards their science and technology lesson than boys.

Karaer (2007) investigated the attitudes of $8^{\text {th }}$ graders about science course regarding some variables. The research was conducted in a state school of Amasya, Turkey. She used an attitude scale consisting of 41 items, and the scale was applied 1088 (556 female, 532 male) students. She concluded that there was a significant difference in attitudes towards science course between the male and female students. The female students had more positive attitudes towards science course than male students. She also found that there was a significant relationship between the attitude towards science course and students' achievements in this course. Students' achievements correlated with their attitudes towards this course.

Relations among attitudes towards science, science achievement, gender, and some other variables were also explored. For instance, Serin and Mohammadzadeh (2008) investigated the relationship between primary school students' attitudes towards science and their science achievements with regard to gender, socioeconomic status, their parents' perceptions about their science achievement and attitudes towards science. Their sample consisted of $2308^{\text {th }}$ graders of whom $64.2 \%$ (212) were female and 35.8\% (118) were male in primary schools in İzmir, Turkey. The results showed that there were significant relationships between all the variables and students' attitudes towards science and their achievement. In other words, gender, socio-economic status, families' perceptions had significant impact on students' attitudes towards science and science achievement. The researcher found boys have more positive attitudes than girls. Furthermore, students having average and good grade have had positive attitudes toward science, and also there was a meaningful relationship between the students' attitudes towards science and their science achievement. 
In an extensive study (National Educational Longitudinal Study), Catsambis (1995) examined gender differences in science achievements and attitudes of $19.0008^{\text {th }}$ graders, and she found that female students did not lag behind in science achievement test and course enrolments. However, female students have less positive attitudes towards science, and also they have less interest in science careers even though they received better grades than males in science classes. As for male students, they were more willing to participate in science classes, and they thought that science would be beneficial for their career. She concluded that positive science-related attitudes are prerequisites for students who pursue studying science as a career.

Furthermore, Sorge et al. (2000) investigated the impact of a Space Science Education Program (SSEP) on middle school $6^{\text {th }}, 7^{\text {th }}$, and $8^{\text {th }}$ graders' attitudes towards science and scientists. The goals of the SSEP were to improve students' attitudes towards science; to improve students' content knowledge about planetary science and scientific method; to familiarize the students with scientific equipment commonly used in many science and engineering fields such as the Scanning Electron Microscope (SEM); and to improve students' knowledge and attitudes about pursuing a career in science or technology. They used two instruments which are "Draw a Scientist" and "Attitude Questionnaire". The instruments were administered to the students before and after the program. In the first measurement, students were asked to draw a scientist and his/her workplace, and in the second measurement, students were asked to complete an attitude questionnaire. The research was conducted through two semesters. In the first semester, forty seven middle school students completed both pre- and post-test sections at the first measurement of the study. At the second measurement, eighty seven students completed both pre- and post-test sections. From the first measurement, they found that more than $70 \%$ of the students believed that scientists use chemistry equipments. Only a few students drew telescopes and even fewer drew computers. Even though all students have seen electron microscope, none of them added this 
to their post-test drawings. From the second measurement, they found that the students had more positive attitudes towards science and scientists after the program and no gender differences were found. Furthermore, at the end of the second semester, students were asked to complete a modified questionnaire, including 28 items, related to attitudes towards science and scientists, and how they perceived science. In this case ( 52 girls and 43 boys completed the forms) there was a significant gender difference in students' attitudes towards science and scientists. While the change in attitudes towards science for boys was significant, that for girls was not significant. All in all, in the first semester of the program, the researchers found a significant change across both genders; in the second semester, they found that only the males had a significant change in their attitudes towards science. Besides, the researchers found that only $30 \%$ of the students wanted to be a scientist or engineer, whereas over $70 \%$ of them thought that working in a lab would be fun.

In the lights of information given above, the review of the literature revealed that the attitude towards science correlates with students' self-concept, achievement, career choices, and content knowledge in science. The students' gender, interest, families' socioeconomic status, perceptions also play an important role in the students' attitude towards science. 


\section{CHAPTER 3}

\section{METHODOLOGY}

This study is designed to investigate the effect of Middle East Technical University's Science Centre (METU SC) on students' attitudes towards science. In addition, this research explores whether there is any change in students' attitudes towards science with regard to their gender, grade levels, and science achievement scores. This study was carried out during the spring semester of the 2008/2009 academic year. This chapter defines population, describes the sample and sampling technique, the research designs and the related research questions. The instruments used for data collection, the procedures used for the implementation of the study, and the statistical procedures used for the analysis of data are also explained elaborately.

\subsection{Population}

All elementary schools in Çankaya district, Ankara, Turkey had been determined as target population for this study, and a design was formed accordingly. However, the Ministry of National Education refused to give permission for this study. According to the Ministry of National Education's regulation, no one can turn students out of school by any means for any research. Consequently, the sample was constituted by selecting the schools' groups who appear in the METU SC's Appointment List during the 2008/2009 school year. Thus, the accessible 
population was limited as well as target population. Target population, for design 1 (see 3.3.1), is all $6^{\text {th }}$ graders in elementary schools in Mamak district, Ankara, Turkey. Accessible population is all $6^{\text {th }}$ graders in Oğuz Kaan elementary school in Mamak district. In a similar way, target population, for design 2 (see 3.3.2), is all $6^{\text {th }}, 7^{\text {th }}$ and $8^{\text {th }}$ graders in elementary schools in Yenimahalle district, Ankara, Turkey. Accessible population is all $6^{\text {th }}, 7^{\text {th }}$ and $8^{\text {th }}$ graders in Göktürk elementary school in Yenimahalle district.

\subsection{Sample and Sampling Technique}

In order to determine sample, METU Science Centre's Appointment List was used. Two schools that are conveniently available for this study were selected. During selection process, the following situations were considered.
a. Appropriateness of date (students' examination dates)
b. The date of permission will be given by the Ministry of National Education.
c. The number of students of schools which will be selected.
d. The district of schools (in or out of Ankara)
e. The grade of students

The researcher interviewed all schools' manager in order to find out the number of students that will visit METU SC. One schools of the current study situated in an area of poor housing and high unemployment which is Oğuz Kaan elementary school at Mamak district. The other school of the current study situated in an area of rich housing and high employment which is Göktürk elementary school in Yenimahalle district. Firstly, the researcher interviewed the student advisor of Mamak Oğuz Kaan elementary school by guidance of school's manager and he 
found out that while some $6^{\text {th }}$ graders were going to visit the METU SC, the rest of them were not. From these $6^{\text {th }}$ graders, both control and experimental groups were constituted conveniently. While the students who were going to visit the METU SC and were selected by their teacher constituted the experimental group, the rest of them constituted the control group of the current study. Thus, both experimental and control group consisted of 46 pupils in each. Secondly, the researcher interviewed with the Trip Club's teacher of Yenimahalle Göktürk elementary school and he found out that all $6^{\text {th }}, 7^{\text {th }}$, and $8^{\text {th }}$ graders were going to come to METU SC for visiting. The selected schools, the number of students participating in the study and their grades were provided in Tables 3.1 and 3.2.

Table 3.1: Characteristics of students of Mamak Oğuz Kaan Elementary School

\begin{tabular}{cccc}
\hline & & $\mathrm{N}$ & $\%$ \\
6th grade & Male & 47 & 51.1 \\
& Female & 45 & 48.9 \\
& Total & 92 & 100 \\
\hline
\end{tabular}

Table 3.2: Characteristics of students of Yenimahalle Göktürk Elementary School

\begin{tabular}{cccc}
\hline \multirow{2}{*}{ Male } & & $\mathrm{N}$ & $\%$ \\
& $6^{\text {th }}$ & 84 & 52.83 \\
& $7^{\text {th }}$ & 30 & 18.87 \\
Female & $8^{\text {th }}$ & 30 & 18.87 \\
& & 24 & 15.09 \\
& $6^{\text {th }}$ & 75 & 47.17 \\
& $7^{\text {th }}$ & 22 & 13.84 \\
Total & $8^{\text {th }}$ & 25 & 15.72 \\
& & 28 & 17.61 \\
\hline
\end{tabular}

One student did not participate in filling out the attitude scale for post-test measure, and five students did not participate in filling out the attitude scale for retention test measure. For this reason, these students were removed from the study. Thus, the sample reduced to 251 students and all of them completed all parts 
of the attitude scale for three measurements over time. The sample $(\mathrm{N}=251)$ consisted of 131 males (52.2\%) and 120 females (47.8\%). The age range of the students varied between 11 and $14(\mathrm{M}=12.71, \mathrm{SD}=0.80)$ with an average of 12.5 years.

\subsection{Designs of the Study}

In this study, two types of design were used: non-equivalent pretest-posttest control group design and one-group pretest-posttest design.

\subsubsection{Design 1}

The quasi-experimental design which is the non-equivalent pretest-posttest control group design was used in order to determine the effect of Middle East Technical University's Science Centre (METU SC) on $6^{\text {th }}$ grade students' attitudes towards science (see Table 3.3). Besides, retention test was administered.

Table 3.3: The Non-Equivalent Pretest-Posttest Control Group Design

\begin{tabular}{cccc}
\hline Treatment Group & 0 & $\mathrm{X}$ & 0 \\
Control group & 0 & $\mathrm{C}$ & 0 \\
\hline
\end{tabular}

In Table 3.3, '0' refers to Pre-test or Post-test (attitude scale); ' $\mathrm{X}$ ' expresses the treatment (Students' visit to METU SC); 'C' implies no treatment (Students' participation in their regular school lessons). The variable that is measured to determine the effects of the experimental treatment is usually referred to as the post-test while a variable that is measured before administering the experimental treatment is usually referred to as the pre-test. 


\subsubsection{Research Questions of Design 1}

Main Research Question: Overall attitudes towards science

1. Is there a change in mean scores of $6^{\text {th }}$ grade students' overall attitudes towards science across the three time periods? It indicates the main effect for time.

2. Are there differences in mean scores of $6^{\text {th }}$ grade students' overall attitudes towards science between the experimental and control group across the three time periods? It indicates the main effect for group.

3. Is there a same change in mean scores of $6^{\text {th }}$ grade students' overall attitudes towards science across the three time periods for the different groups (experimental and control group)? It indicates the interaction effect for time by group.

Sub-research questions with respect to factors of attitude scale:

Sub- research question 1: Attitudes towards learning science in school

1. Is there a change in mean scores of $6^{\text {th }}$ grade students' attitudes towards learning science in school across the three time periods?

2. Are there differences in mean scores of $6^{\text {th }}$ grade students' attitudes towards learning science in school between the experimental and control group across the three time periods?

3. Is there a same change in mean scores of $6^{\text {th }}$ grade students' attitudes towards learning science in school across the three time periods for the different groups (experimental and control group)? 
Sub- research question 2: Attitudes towards self-concept in school science

1. Is there a change in mean scores of $6^{\text {th }}$ grade students' attitudes towards self-concept in school science across the three time periods?

2. Are there differences in mean scores of $6^{\text {th }}$ grade students' attitudes towards self-concept in school science between the experimental and control group across the three time periods?

3. Is there a same change in mean scores of $6^{\text {th }}$ grade students' attitudes towards self-concept in school science across the three time periods for the different groups (experimental and control group)?

Sub- research question 3: Attitudes towards practical work in school science

1. Is there a change in mean scores of $6^{\text {th }}$ grade students' attitudes towards practical work in school science across the three time periods?

2. Are there differences in mean scores of $6^{\text {th }}$ grade students' attitudes towards practical work in school science between the experimental and control group across the three time periods?

3. Is there a same change in mean scores of $6^{\text {th }}$ grade students' attitudes towards practical work in school science across the three time periods for the different groups (experimental and control group)?

Sub- research question 4: Attitudes towards science outside of school

1. Is there a change in mean scores of $6^{\text {th }}$ grade students' attitudes towards science outside of school across the three time periods? 
2. Are there differences in mean scores of $6^{\text {th }}$ grade students' attitudes towards science outside of school between the experimental and control group across the three time periods?

3. Is there a same change in mean scores of $6^{\text {th }}$ grade students' attitudes towards science outside of school across the three time periods for the different groups (experimental and control group)?

Sub- research question 5: Attitudes towards future participation in science

1. Is there a change in mean scores of $6^{\text {th }}$ grade students' attitudes towards future participation in science across the three time periods?

2. Are there differences in mean scores of $6^{\text {th }}$ grade students' attitudes towards future participation in science between the experimental and control group across the three time periods?

3. Is there a same change in mean scores of $6^{\text {th }}$ grade students' attitudes towards future participation in science across the three time periods for the different groups (experimental and control group)?

Sub- research question 6: Attitudes towards importance of science

1. Is there a change in mean scores of $6^{\text {th }}$ grade students' attitudes towards importance of science across the three time periods?

2. Are there differences in mean scores of $6^{\text {th }}$ grade students' attitudes towards importance of science between the experimental and control group across the three time periods? 
3. Is there a same change in mean scores of $6^{\text {th }}$ grade students' attitudes towards importance of science across the three time periods for the different groups (experimental and control group)?

\subsubsection{Design 2}

The one-group pretest-posttest design was used in order to determine the effect of Middle East Technical University's Science Centre (METU SC) on students' attitudes towards science (see Table 3.4). Besides, it investigates whether there is any difference between students' attitudes towards science with regard to their gender, grade levels, and science achievement scores.

Table 3.4: The one-group pretest-posttest design

\begin{tabular}{ccc}
\hline 0 & $\mathrm{X}$ & 0 \\
Pre-test & Visit to METU SC & Post-test \\
\hline
\end{tabular}

\subsubsection{Research Questions of Design 2}

Research Question 1: Overall attitudes towards science with respect to gender

1. Is there a change in students' mean attitude scores towards science over the three time periods?

2. Is there an impact of gender type on mean attitude scores towards science?

3. Is there a same change in mean attitude scores towards science over the three time periods for boys and girls? 
Research Question 2: Overall attitudes towards science with respect to grade levels

1. Is there a change in students' mean attitude scores towards science across the three time periods?

2. Is there an impact of grade levels on mean attitude scores towards science across the three time periods?

3. Is there a same change in mean attitude scores towards science across the three time periods for different graders?

Research Question 3: Overall attitudes towards science with respect to science $\underline{\text { achievement scores }}$

1. Is there a change in mean attitude scores towards science over time?

2. Is there an impact of science achievement scores (SAS) on students' mean attitude scores?

3. Is there a same change in mean attitude scores towards science over time for students with different science achievement scores (SAS)?

"The variable to be manipulated literally is referred as the experimental treatment, treatment variable, experimental variable or independent variable.” (Borg \& Gall, 1979, p. 521). In this study, the variable to be manipulated is referred as the independent variable. The independent variable manipulated was the visit to the METU's Science Centre. The dependent variables which are students' attitudes 
towards science scores were evaluated using one instrument. A pre-test was administered before the start of this study. One week later, a post-test was implemented immediately after the visit to the METU SC, and retention test was administered one week after the visit. The data collection process started on 17 March, 2009 and finished on 7 April, 2009 for both designs.

\subsection{Instruments}

In this study, two instruments were used which are "Information Collection Form" and "Attitude towards Science Scale".

\subsubsection{Information Collection Form}

The purpose of the information collection form is to obtain information about students (e.g., science achievement score, gender, age, grade, socioeconomic status), and to determine whether there is any interaction between some of these variables and students' attitudes towards science (see Appendix A).

\subsubsection{Attitude Scale}

Kind et al. (2007) developed an attitude scale on behalf of the Institute of Physics in the United Kingdom in order to evaluate the impact of "Lab in a Lorry"; a mobile laboratory that visited schools and used to demonstrate a series of experiments to students aged 11-14 (see Appendix B). They combined a couple of areas of attitudes to science in their scale which are "Learning science in school", 
"Practical work in science", "Science out of school", "Importance of science", "Self-concept in science", "Future participation in science", and "General Sciencerelated Attitudes to School". "There are many types of scale in the literature. Tittle and Hill (1967) compared the effectiveness of various types of attitudes scales which are Self-Rating, Semantic Differential, Gultman, Thurstone and Likert predicting objective indices of voting behaviour and they found that the Likert one is superior to all other scale types (p. 275)" (as cited in Borg \& Gall, 1979). By adopting Likert-scale format, students were forced to a choice from five responses given for each statement that are 'strongly agree', 'agree', 'neither agree nor disagree', disagree', and 'strongly disagree'. The scale was administered to students twice, two weeks before the visit of Lab in a Lorry, and two weeks after. The scale for pre-measure was completed by 932 students, and 668 students completed it for the post-measure. Cronbach $\alpha$ values obtained by reliability calculations were higher than the threshold of 0.70 for both pre- and post-measure.

In this study, “Attitude towards Science Scale” developed by Kind et al. (2007) was used with some modifications. The original scale consists of 46 attitude statements. Even though original scale has attitude statements towards school (the statements between the $38^{\text {th }}-46^{\text {th }}$ items), these statements are out of scope of this study (see Appendix B). Therefore these items were removed from the original scale. Then, the researcher received expert opinions for original scale's statements. The three experts from faculty of education of METU, one expert from faculty of education of Mersin University, one expert from faculty of education of Gazi University and $12 \mathrm{Ph}$.D. students studying science education revised the statements. They suggested that some statements should be removed and some statements should be reduced by combination. The following statements were advised to be removed from the scale because of several reasons. The first reason provided by the experts is that the first two of these items state a particular condition for the attitude which blocks the students' expression of their attitudes unconditionally. The second reason is that these items are not appropriate to 
Turkey's conditions. The experts agreed that most of the schools, especially state schools, do not have furnished science laboratories. Even if we assume the state schools have, students generally cannot make their own decisions during the implementation of the experiments. The last item was advised to be removed simply because the relation between science/technology and poor is very indirect.

1. Practical work in science is good because I can work with my friends.

2. I like practical work in science because I can decide what to do myself.

3. Science and technology are helping the poor.

The following statements were advised to be reduced because most of the students differentiate school science from science, and they also know what will happen at the end of the practical works. The experts claimed that while students agree with the statement: "I would like to have a job working with science", they may not agree with the statement: "I would like to become a science teacher" or vice versa. In this respect, these statements might conflict with each other, and they do not reflect true attitudes of students.

1. I like science practical work because you don't know what will happen.

2. I would like to have a job working with science.

3. I would like to become a science teacher.

Therefore, $1^{\text {st }}$ statement was reduced and final statement was put in the form as "I like science practical work." $2^{\text {nd }}$ and $3^{\text {rd }}$ statements were combined and final statement was formulated as "I would like to have a job working with science and technology." With these modifications, the original scale was reduced to 33 items. The researchers took permission for translation and adaptation of related items of the scale (see Appendix C), and original scale was translated and adapted into Turkish by the researcher. The translation into Turkish and again into English was 
carried out by the research assistants of faculty of education of METU ( $n=6)$, the research assistants of department of Basic English of METU (n=3), and Ph. D. students in different English speaking countries $(n=28)$. The most repeated translation statements were chosen in order to constitute final statements in the scale. After the translation process, the final statements in the scale were checked whether it overlaps or conflicts with the original statements by three experts from faculty of education of METU. The final version of the scale was revised and the researcher administered to some students that have visited the METU SC and he interviewed with students about the statements. By interviewing the students, it was realized that some statements were not understood by the students. As a result, wording of related statements was corrected, and the final format of the scale was constituted (see Appendix D). Then, it was piloted by using 114 students (49.9\%) male and (50.9) female with different grades $\left(6^{\text {th }}(54.4 \%), 7^{\text {th }}(27.2 \%)\right.$ and $8^{\text {th }}$ (18.4\%)) who came to science centre of METU for visiting from two different regions which are Mamak and Yenimahalle, and reliability coefficient Cronbach $\alpha$ was found to be .941 .

\subsection{Procedures of Data Collection}

Before data collection process, first of all, the design of the research was set up and the related variables were determined. Secondly, the permission of METU's Ethical Committee was taken for conducting the research. Thirdly, the permission of the Ministry of National Education of Turkey was taken (see Appendix E). The process of taking permission took approximately two months. Then, the researcher visited the selected schools with permission documents. He interviewed the schools' managers, and informed them about the research. The days of the data collection were decided together. Students' documents about their participation voluntarily (see Appendix F) and parents' consent documents (see Appendix G - 
H) were given them out by their teachers. After all, the implementation of the data collection was started in determined days for each school. The researcher informed the teachers of the students who attend to the current study about how to collect data appropriately. Students were told that their responses definitely will not be revealed to anyone, especially their teachers, family members, and results will be used only for scientific purposes without revealing their identities. The scale was administered, collected, put into sealed envelope, and delivered to the researcher by the teachers. Data collection occurred throughout three weeks for each group and 257 elementary level students participated from two different schools.

\subsubsection{First Measurement (PRETEST)}

Pre-measure was administered in the selected schools. For each school's premeasures, the scales were given to the students who accepted to participate voluntarily, and whose parents' gave the consent by their teachers. After the implementation, the completed scales were taken by the researcher. Name and surname of the students was obtained through information collection form. All students were coded with numbers. Thus, the researcher used the numbers of students instead of their names. After the first implementation, the scale was coded with numbers according to students' names and in the second and third implementations of the scale, these numbers were used. After the data collection process was completed, all students' names and surnames were destroyed; only the numbers that represent students was kept. 


\subsubsection{Second Measurement (POSTTEST)}

When the participated classes of schools come to the METU SC, firstly, students were invited to the conference hall and Middle East Technical University and the METU SC was briefly introduced to them. Then, the presentation of exhibits which is called 'science show' was started by the researcher. All science shows during research were performed by the researcher. Wellington (1998) classified the exhibits located at science centres into two types which are pedagogical and experiential. The pedagogical exhibits provide helping the visitors learn something such as reflection of light, the properties of concave or convex mirrors etc. On the other hand, the experiential ones provide the visitors to experience phenomena such as water vortices, human gyroscope etc (as cited in Pedretti, 2004). These categorizations are useful and helpful for many science centres due to the fact that they provide a layout of the exhibits at science centres (Pedretti, 2004). The exhibits at METU SC were also classified in this manner. In order to understand the nature of science, to comprehend the relationships between science-societyenvironment, to develop interest and attitude towards science, students are required to know the science concepts (Demirelli et al, 2006). For this reason, some exhibits which can also be called experiments were elaborately explained, and performed with the students. During the visit, throughout 40 minutes, the following exhibits were performed on the stage for all groups:
1. Robot show
2. Liquid Nitrogen
3. Vortex in the water
4. Vortex in the air
5. Bernoulli blower (Bernoulli's principle)
6. Conservation of angular momentum (Ice skater)
7. Benham's disc
8. Praxinescope 
9. $\quad$ Floating rings

10. Convex-Concave mirrors

11. Microscope

12. Plasma Ball

The purpose of the exhibits in science centres was not to change the world, however, to change visitors' perception of how the world works (Walton, 2000). After interaction with exhibits, visitors were expected to think differently than before about how the world works (Walton, 2000). Discussion technique was used while science shows were conducted on stage due to the fact that settling a disagreement among visitors is critical to learning (Vygotsky, 1978). After the presentation of the exhibits, all students were let free to discover and explore the other exhibits in the science centre as well as the presented exhibits. The structure of a visit can vary from free exploration of exhibits to a passive explainers-led tour because students not only need some guidance through their visits but also they need some free exploration time (Linn, 1980 as cited in Rennie \& McClafferty, 1995). All students were given 20 minutes for their own discovery and exploration. During students' exploration, the researcher helped the students who required. Russell (1990) pointed out that explainers in science centres provide cues by asking questions to help students to attend to significant aspects of the exhibits. The presence of explainers is crucial (Rennie \& McClafferty, 1995) due to the fact that students have different backgrounds, interests and abilities, they will interact with the exhibits differently and hence they need different kinds of help (Gottfried, 1979, as cited in Rennie \& McClafferty, 1995). After the exploration and discovery section, the attitude scale was administered as a post measure. In total, students spent 80 minutes at the science centre for this research.

While students in experimental group have visited the METU SC, those in control group have continued their regular school lessons in their classes. Besides, while students in experimental group have completed the attitude scale in METU SC, 
those in control group have completed in their classes at the same time. The scale was given to all students in control group in their classes by their teachers and the completed scales were delivered to the researcher.

\subsubsection{Third Measurement (RETENTION TEST)}

Final data collection was administered in each school one week after the visit to the METU SC. The scale was given to all students in their classes by their teachers and the completed scales were delivered to the researcher.

\subsection{Data Coding}

The students checked one of the five possible responses to each statement which are "strongly agree, agree, undecided (neither agree nor disagree), disagree, strongly disagree". Items on scale which refer to "strongly agree" indicate a positive attitude and be scored 5. Items on scales which refer to "strongly disagree" point out a negative attitude and be scored 1 . Attitude scale used in this study has some negatives questions. During coding process, these items were coded reversely that "strongly disagree" responses were coded with 5 while "strongly agree" ones were coded with 1. 


\subsection{Data Analyses}

The available data were analyzed by using SPSS 15 (Statistical Package for Social Sciences) in terms of descriptive and inferential statistics. Repeated measures analysis of variance with mixed (within-between) design and paired t-tests were used to test the proposed hypotheses.

Before running the detailed analyses, the data were controlled in order to identify the erroneous entries. Minimum and maximum values, frequencies of major variables were skimmed, and scores which were not in the range of possible values were corrected. Missing values were not greater than 5\%. 5\% or less missing values do not lead serious errors and produce similar results (Tabachnick \& Fidell, 2001). For this reason, missing value analysis was not performed. Firstly, the reliability analysis of the attitude scale was performed on the data collected during the pilot study. The reliability coefficient of the attitude scale was found to be .941 . Table 3.5 shows the reliability coefficients found from the measurements collected at different times. Then, the researcher has evaluated the 'Item-Total Statistics' results of the scale's items according to the results of the pilot study. The items whose 'Corrected-Item Correlation' values are equal to .30 or lesser are not accepted due to the fact that these items do not discriminate people who have positive or negative attitudes (Atılgan, Doğan, \& Kan, 2006). According to the results, none of the items needed to be removed from the scales because all the values were above .30 . Then, the exploratory factor analysis was used to analyze the correlation between a number of variables in order to reduce them to a smaller number of underlying dimensions, called factors, and to determine the correlation of each of the original variables with each factor. For these purposes principal components extraction and varimax rotation was performed on the data of the pilot study. Kaiser-Meyer-Olkin Measure of Sampling adequacy (.86) was above .50 and Barlett's test of sphericity rejects the hypothesis at $p<.001$ (i.e., the correlation matrix is an identity matrix without significant correlations between variables), 
which confirms that the data are suitable for factor analysis (Colman \& Pulford, 2006). Six factors were extracted, and all of them explain 71.23 per cent of the variance in the original measures. The first extracted factor explained 38.6 per cent and the second one explained 10.59 per cent of the variance in the original measures (see Appendix I-J). It was sufficient if the value of total variances explained was at least $60 \%$. The Eigenvalue at second factor was 3.5. When this value multiplies with 3, it can be seen that the value obtained (10.5) is approaching to the Eigenvalue (12.7) at first factor. This situation points out that the attitude scale is unidimensional (Albayrak, 2006). By examining and adapting the factors of the attitude scale developed by Kind and his colleagues (2007), six factors were identified as the following: 'Learning Science in School', 'Self-Concept in School Science', 'Practical Work in School Science', 'Science Outside of School', 'Future Participation in Science', 'Importance of Science'.

Table 3.5: The Reliability Coefficients of Attitude Scale for Three Measurements

\begin{tabular}{cccc}
\hline & Time 1 & Time 2 & Time 3 \\
\hline Oğuz Kaan Elementary School $(\mathrm{N}=92)$ & .94 & .95 & .95 \\
Göktürk Elementary School $(\mathrm{N}=159)$ & .94 & .94 & .94 \\
Overall(N=251) & .94 & .94 & .95 \\
\hline
\end{tabular}

Table 3.6: KMO and Bartlett's Test Results for Attitude Scale

\begin{tabular}{ccc}
\hline \multicolumn{2}{c}{ Kaiser-Meyer-Olkin Measure of Sampling Adequacy. } & .86 \\
& Approx. Chi-Square & 2594.39 \\
Bartlett's Test of Sphericity & Df & 528 \\
& Sig. & .000 \\
\hline
\end{tabular}

In this study, repeated measures (within-between) mixed design was used for inferential analysis. Detailed information about this measure was provided in the following section. 


\subsubsection{Mixed-Design Repeated Measures}

“"Repeated measure' is a term used when the same people participate in all conditions of an experiment" (Field, 2005, p.427). In this study, the researcher investigated the effect of METU SC on students' attitudes towards science. While some students might improve their attitudes, the others might not. Therefore, it was important to determine the effect of METU SC on students' attitudes. For this purpose, every participant provided a score representing her/his attitude before the experimental manipulation (visit to METU SC), immediately after the manipulation, and one week later. This type of design requires 'Repeated measure'. “'Repeated measure' has several advantages. Most importantly, it reduces the unsystematic variability in the design and so provides greater power to detect effects. It is also more economical because fewer participants are required" (Field, 2005, p.428).

The assumptions of this design are normal distribution of scores across groups, equal variances of scores across groups, and homogeneity of intercorrelations. First assumption for both designs was checked step by step, and it was seen that scores was approximately normally distributed. Second and third assumption was specified in the results section due to the fact that they were tested as part of the analysis. While the assumption that is equal variances of scores across groups was determined by using Levene's test statistic the assumption that is homogeneity of intercorrelations was determined by using Box's M statistic.

The proportion between the numbers of students of groups was less than 1.5 for two designs. Several researchers argued that even if the Levene's test results are violated, these violations will not cause any problem since the proportion between the numbers of students of groups is less than 1.5 (Hair, Anderson, Tatham, \& William, 1995; Stevens, 1996). Therefore, the researcher did not present the Levene's test statistics results. 
If the Box's M statistic is significant in any design, the researcher will report the Pillai's trace value instead of Wilks' Lambda because of the fact that Pillai's trace is more robust to violations of the homogeneity of variances and covariances (Rebecca, 2007; Tabachnick \& Fidell, 2001).

Most importantly, in mixed within-between analysis of variance, SPSS produces a test known as Mauchly's test, which tests the hypothesis that the variances of the differences between conditions are equal. If Mauchly's test of sphericity is violated, Stevens (2002) and Field (2005) recommended that multivariate results are more powerful, whereas when sphericity holds the univariate results should be presented. Therefore, if Mauchly's test of sphericity is violated, the researcher will present the multivariate results. If it is not, the researcher will present the univariate results.

The researcher also used the pairwise comparisons obtained by Bonferroni method in order to compare main effects in mixed within-between design due to the fact that "in terms of Type 1 error rates the Bonferroni method is best; and also when sphericity is violated, the Bonferroni method seems to be generally the most robust of the univariate techniques, especially in terms of power and control of the Type 1 error rate" (Field, 2005, p. 442).

Furthermore, the researcher used paired t-tests in order to explain the effects elaborately. Furthermore, the adjustment of level of significance was conducted with regard to Bonferroni- correction significance level. Bonferroni correction to the significance level should be applied to protect against a Type 1 error arising from the use of repeated tests. According to this correction, the corrected significance level is obtained by dividing the significance level of .05 by the number of pair. For this reason, the corrected significance level was equal to .017 by (.05/3), and it was used in paired t-tests (Colman \& Pulford, 2006). The 
following equation was used in the calculation of effect size in paired t-test (Pallant, 2005, p.212):

Eta squared $\left(\eta^{2}\right)=t^{2} /\left[t^{2}+(N-1)\right],(N-1)=d f($ degrees of freedom $)$

\subsection{Assumptions}

The following assumptions were made for this study:

1. In this study, Likert-type scales were used, and the researcher assumed that all students understand the meaning of the statements and are sincere in their responses.

2. Although we can never be sure of the degree to which the subjects' responses reflect their true attitudes in the attitude scales, the researcher assumed that subjects' responses reflect their true attitudes.

3. The data were recorded and analyzed accurately.

4. Pre-test was not interacted with the treatment.

5. There were no interactions between the students of different groups.

\subsection{Limitations}

1. The study is limited to $2008 / 2009$ school year.

2. This study is limited to $6^{\text {th }}$ grade students from Mamak Oğuz Kaan and $6^{\text {th }}$, $7^{\text {th }}, 8^{\text {th }}$ graders from Yenimahalle Göktürk elementary school.

3. This study is limited to only 251 students participated.

4. This study is limited to METU SC. 
5. This study is limited to only one visit to METU SC.

6. This study is limited to only one session lasting 60 minutes during visit to METU SC.

7. In this study, the attitude scale was administered one week before, immediately after and one week after a visit to METU SC. For this reason, this study is limited to one-week time intervals.

\subsection{Internal Validity}

Whether the dependent variable are directly related to the independent variable or related to some extraneous variables will determine the internal validity of the study. This section presents possible threats to the study for both designs. Fraenkel and Wallen (1932) described the threats to the internal validity of a study as the following: subject characteristics (gender, previous knowledge, age, maturity, socio economic status, ethnicity, etc.), loss of subjects (mortality), location, instrumentation, data collector characteristics, testing, history, maturation, Hawthorn effect (attitude of subjects), regression, and implementation.

\subsubsection{Internal Validity for Design 1}

In this study, since the control group and the experimental group were selected conveniently rather than assigning the individuals randomly to both groups, subject characteristics such as previous science knowledge, gender, age, maturity, attitude, socioeconomic status, and ethnicity should be discussed as threats. However, in terms of several characteristics, the groups were not significantly different from 
each other (see Appendix K for detailed discussions about the subject characteristics).

Loss of subjects (mortality) is not a threat to the study because of the fact that none of the students dropped out of the study as it progressed.

Data collector characteristics are unlikely to be an effective threat due to the fact that except the second measurement the same data collectors (teachers) were used in the current study over time, all procedures were standardized and the data collectors (teachers) were trained.

Testing is likely to be a threat due to the fact that the change or unchange in attitude scores may be due to the students' remembering, thinking, or discussing their opinions after the pretest rather than as a result of the intervention.

History effect is likely to be a threat due to the fact that one or more unexpected events might be occurred during the periods of data collection that can affect the responses of subjects.

Maturation cannot be an important threat because of the fact that study was conducted through three weeks. In such a short time, maturation is unlikely to be an important threat.

Since the students in experimental and control groups were determined by their teachers before, Hawthorne effect can be considered as a threat; students knew whether they were going to METU SC or not. However, students in control group or experimental group probably did not feel that they were subjected to a discrimination or an award because they were informed that the students in control group were going to visit the METU SC at a later time. For this reason, Hawthorne effect is unlikely to be an effective threat to the study. 
Regression is unlikely to be an effective threat because of the fact that there were no significant differences between the students in experimental and control groups with respect to their characteristics such as previous science knowledge and attitude scores.

Implementation can also be considered as a threat due to the fact that students' instructors and the implementer of the visit were different. However, this is unovaidable because of the nature of out of scholl environments.

Location may be considered as a threat due to the fact that the scales were administered under the different conditions for both groups. While the students in the control group completed the scale in their school, the students in the experimental group completed the scale in METU SC at second measurement. However, location and implementation were not considered as a significant threats due to the fact that the current study investigated the effect of METU SC on students' attitudes and METU SC was considered as a whole including its location, building's shape, building's lighting, landscaping, explainers etc. Furthermore, possible threats due to location or implementer can be easily tracked because of the fact that the retention test was administered under the same conditions.

\subsubsection{Internal Validity for Design 2}

There may be many possible threats for design 2 due to the fact that there was no comparison group. Subject characteristics such as age, gender, previous knowledge, maturity, socioeconomic status, and ethnicity are likely to be threat to the study. In order to control some of these threats such as gender, age (grade levels), previous knowledge (science achievement scores), they were investigated as a part of the study and the results showed that the impact of METU SC was 
independent from students' gender, age (grade levels), and previous knowledge (science achievement scores).

Loss of subjects (mortality) is unlikely to be an effective threat to the study because of the fact that students who dropped out of the study were removed from the study $(\mathrm{N}=6)$.

Maturation, data collector characteristics, implementation, location are also unlikely to be effective threat due to the same reasons discussed in section 3.11.1.

Nonetheless, there may still be possible threats such as Hawthorne, testing, history, and regression.

\subsection{External Validity}

The subjects of this study were 251 students who were not selected randomly from the population. Therefore, generalization of this study is limited. The generalizability of this study would be acceptable for the groups whose characteristics and environmental conditions are similar to the sample of this study. The characteristics of METU SC such as the exhibits and guides are probably different from those of the other science centres and the results can be generalized only to the science centres that have similar characteristics. 


\section{CHAPTER 4}

\section{DATA ANALYSIS AND RESULTS}

This chapter was divided into two sections to present the detailed statistical analysis performed to respond to the research questions. The first section presents the analysis for Design 1 and the second section presents the analysis for Design 2.

\subsection{The Analysis for Design 1}

The main purpose of the design 1 was to determine the impact of Middle East Technical University's Science Centre on $6^{\text {th }}$ grade students' overall attitudes towards science; and to determine the impact of Middle East Technical University's Science Centre on $6^{\text {th }}$ grade students' attitudes towards science with respect to the factors of the attitude scale, which are "Learning science in school", "Self-concept in school science", "Practical work in school science", "Science outside of school", "Future participation in science", and "Importance of science". 


\subsubsection{Main Research Question 1}

Main Research Hypothesis: Overall attitudes towards science

$\mathrm{H}_{1}$ : There is no change in mean scores of $6^{\text {th }}$ grade students' overall attitudes towards science across the three time periods? It indicates the main effect for time.

$\mathrm{H}_{2}$ : There are no differences in mean scores of $6^{\text {th }}$ grade students' overall attitudes towards science between the experimental and control group across the three time periods? It indicates the main effect for group.

$\mathrm{H}_{3}$ : The change is not the same in mean scores of $6^{\text {th }}$ grade students' overall attitudes towards science across the three time periods for the different groups (experimental and control group)? It indicates the interaction effect for time by group.

The distribution of students with respect to their gender, age, science achievement scores are provided in Table 4.1. 
Table 4.1: Descriptive Statistics of Demographic Variables

\begin{tabular}{|c|c|c|c|c|c|c|c|}
\hline & & \multicolumn{2}{|c|}{ Total } & \multicolumn{2}{|c|}{$\begin{array}{c}\text { Experimental } \\
\text { Group }\end{array}$} & \multicolumn{2}{|c|}{$\begin{array}{l}\text { Control } \\
\text { Group }\end{array}$} \\
\hline & & $\mathrm{N}$ & $\%$ & $\mathrm{~N}$ & $\%$ & $\mathrm{~N}$ & $\%$ \\
\hline \multicolumn{8}{|l|}{ GENDER } \\
\hline & Male & 47 & 51.1 & 20 & 43.5 & 27 & 58.7 \\
\hline & Female & 45 & 48.9 & 26 & 56.5 & 19 & 41.3 \\
\hline \multicolumn{8}{|l|}{ AGE } \\
\hline & 11 & 3 & 3.3 & & & 3 & 6.5 \\
\hline & 12 & 61 & 66.3 & 33 & 71.7 & 28 & 60.9 \\
\hline & 13 & 27 & 29.3 & 13 & 28.3 & 14 & 30.4 \\
\hline & 14 & 1 & 1.1 & & & 1 & 2.2 \\
\hline \multicolumn{8}{|c|}{ Science Achievement Score (SAS) } \\
\hline & Fail & 5 & 5.4 & 2 & 4.3 & 3 & 6.5 \\
\hline & Passable & 11 & 12.0 & 4 & 8.7 & 7 & 15.2 \\
\hline & Average & 27 & 29.3 & 13 & 28.3 & 14 & 30.4 \\
\hline & Good & 30 & 32.6 & 13 & 28.3 & 17 & 37.0 \\
\hline & Excellent & 19 & 20.7 & 14 & 30.4 & 5 & 10.9 \\
\hline Total & & 92 & 100 & 46 & 100 & 46 & 100 \\
\hline
\end{tabular}

The descriptive statistics for mean attitude scores of both groups across the three time periods can be seen in Table 4.2.

Table 4.2: Descriptive Statistics for Attitude Scores of Both Groups

\begin{tabular}{ccccc}
\hline & Group & $\mathrm{M}$ & $\mathrm{SD}$ & $\mathrm{N}$ \\
\hline Time 1 & Experimental & 130.98 & 22.07 & 46 \\
& Control & 124.00 & 22.68 & 46 \\
& Total & 127.49 & 22.53 & 92 \\
Time 2 & Experimental & 145.70 & 18.14 & 46 \\
& Control & 125.30 & 21.12 & 46 \\
& Total & 135.50 & 22.10 & 92 \\
Time 3 & Experimental & 142.70 & 20.08 & 46 \\
& Control & 124.78 & 24.62 & 46 \\
& Total & 133.74 & 24.09 & 92 \\
\hline
\end{tabular}

Mauchly's test indicated that the assumption of sphericity had not been violated $\left[\chi^{2}\right.$ $(2)=2.54, p=.281>.050]$; therefore sphericity assumed $F$ test results for time 
and group were used. A mixed-model analysis of variance revealed that the main effect for time was significant, $F(2,180)=13.59, \mathrm{p}=.000<.050, \eta^{2}=.13$ indicating a moderate effect (Cohen, 1988 as cited in Pallant, 2005) (see Table 4.3). Bonferroni pairwise comparisons result for time revealed that there was a significant increase in mean attitude scores from Time $1(\mathrm{M}=127.49, \mathrm{SE}=2.33)$ to Time $2(\mathrm{M}=135.50, \mathrm{SE}=2.05)$. Furthermore, there was a significant difference between Time $1(\mathrm{M}=127.49, \mathrm{SE}=2.33)$ and Time $3(\mathrm{M}=133.74, \mathrm{SE}=2.34)$. However, there was no significant difference between the Time $2(M=135.50$, $\mathrm{SE}=2.05)$ and Time $3(\mathrm{M}=133.74, \mathrm{SE}=2.34)$.

A significant time* group interaction effect was also obtained, $F(2,180)=9.77$, $\mathrm{p}=.000<.050, \eta^{2}=.10$ indicating a moderate effect (Cohen, 1988 as cited in Pallant, 2005) (see Table 4.3). This result revealed that the change in mean attitude scores across the three time periods was not the same for experimental and control groups.

A significant main effect for group was also obtained, F $(1,90)=13.64$, $\mathrm{p}=.000<.050, \eta^{2}=.13$ indicating a moderate effect (Cohen, 1988 as cited in Pallant, 2005) (see Table 4.3). Bonferroni pairwise comparisons result for group revealed that there was a significant difference in mean attitude scores between the experimental $(\mathrm{M}=139.79, \mathrm{SE}=2.89)$ and the control groups $(\mathrm{M}=124.70, \mathrm{SE}=2.89)$.

Table 4.3: Analysis of Variance Results for Effects

\begin{tabular}{cccccc}
\hline Source & SS & df & MS & F & $\eta 2$ \\
\hline Between subjects & & & & & \\
Group & 5240 & 1 & 5240 & $13.64^{* *}$ & .13 \\
Error & 34587 & 90 & 384 & & \\
Within Subjects & & & & & \\
Time & 3261 & 2 & 1631 & $13.59^{* *}$ & .13 \\
Time*Group & 2343 & 2 & 1172 & $9.77^{* *}$ & .10 \\
Error & 21593 & 180 & 120 & & \\
\hline
\end{tabular}

Note. ${ }^{*} \mathrm{p}<.05,{ }^{* *} \mathrm{p}<.001$. 
In the lights of information given above, while $\mathrm{H}_{1}$ and $\mathrm{H}_{2}$ were rejected, $\mathrm{H}_{3}$ was failed to reject. Furthermore, in order to determine the change in mean attitude scores of students in both groups over time, paired t-tests were conducted.

\section{Paired T-test for Experimental Group}

There was a significant increase in mean attitude scores from Time $1(\mathrm{M}=130.98$, $\mathrm{SD}=22.07)$ to Time $2(\mathrm{M}=145.70, \mathrm{SD}=18.14), \mathrm{t}(45)=-4.92, \mathrm{p}=.000, \eta^{2}=.35$ indicating very large effect (Cohen, 1988 as cited in Pallant, 2005). Moreover, there was a significant difference in mean attitude scores between Time 1 $(\mathrm{M}=130.98, \mathrm{SD}=22.07)$ and Time $3(\mathrm{M}=142.70, \mathrm{SD}=20.08), \mathrm{t}(45)=-4.83$, $\mathrm{p}=.000, \eta^{2}=.34$ indicating very large effect (Cohen, 1988 as cited in Pallant, 2005). Nevertheless, there was no significant difference in mean attitude scores between Time $2(\mathrm{M}=145.70, \mathrm{SD}=18.14)$ and Time $3(\mathrm{M}=142.70, \mathrm{SD}=20.08)$, $\mathrm{t}(45)=1.26, \mathrm{p}=.213, \eta^{2}=.003$ indicating very small effect size (Cohen, 1988 as cited in Pallant, 2005).

Table 4.4: Paired T-test Results for Experimental Group

\begin{tabular}{|c|c|c|c|c|c|c|c|c|c|}
\hline \multirow[b]{3}{*}{ Pair } & \multirow[b]{3}{*}{ Time } & \multicolumn{5}{|c|}{ Paired Differences } & \multirow[b]{3}{*}{$\mathrm{T}$} & \multirow[b]{3}{*}{ df } & \multirow[b]{3}{*}{$\eta 2$} \\
\hline & & \multirow[b]{2}{*}{ MD } & \multirow[b]{2}{*}{$\mathrm{SD}$} & \multirow[b]{2}{*}{ SE } & \multicolumn{2}{|c|}{$95 \% \mathrm{CI}$} & & & \\
\hline & & & & & $\begin{array}{l}\text { Lower } \\
\text { Limit }\end{array}$ & $\begin{array}{l}\text { Upper } \\
\text { Limit }\end{array}$ & & & \\
\hline 1 & $1-2$ & -14.72 & 20.29 & 2.99 & -20.74 & -8.69 & $-4.92 * *$ & 45 & .35 \\
\hline 2 & $1-3$ & -11.72 & 16.46 & 2.43 & -16.60 & -6.83 & $-4.83 * *$ & 45 & .34 \\
\hline 3 & $2-3$ & 3.00 & 16.11 & 2.37 & -1.78 & 7.78 & 1.26 & 45 & .003 \\
\hline
\end{tabular}

\section{Paired T-test for Control Group}

There were no significant differences in mean attitude scores over time. There was no significant increase in mean attitude scores from Time $1(\mathrm{M}=124.00$, 
$\mathrm{SD}=22.68)$ to Time $2(\mathrm{M}=125.30, \mathrm{SD}=21.12), \mathrm{t}(45)=-.74, \mathrm{p}=.461, \eta^{2}=.01$

indicating small effect (Cohen, 1988 as cited in Pallant, 2005). Besides, there was no significant difference in mean attitude scores between Time $1(\mathrm{M}=124.00$, $\mathrm{SD}=22.68)$ and Time $3(\mathrm{M}=124.78, \mathrm{SD}=24.62), \mathrm{t}(45)=-.38, \mathrm{p}=.709, \eta^{2}=.003$ indicating very small effect (Cohen, 1988 as cited in Pallant, 2005). And also, there was no significant difference in mean attitude scores between Time 2 $(\mathrm{M}=125.30, \mathrm{SD}=21.12)$ and Time $3(\mathrm{M}=124.78, \mathrm{SD}=24.62), \mathrm{t}(45)=.28$, $\mathrm{p}=.778, \quad \eta^{2}=.001$ indicating very small effect size (Cohen, 1988 as cited in Pallant, 2005).

Table 4.5: Paired T-test Results for Control Group

\begin{tabular}{|c|c|c|c|c|c|c|c|c|c|}
\hline \multirow[b]{3}{*}{ Pair } & \multirow[b]{3}{*}{ Time } & \multicolumn{5}{|c|}{ Paired Differences } & \multirow[b]{3}{*}{$\mathrm{t}$} & \multirow[b]{3}{*}{ df } & \multirow[b]{3}{*}{$\eta 2$} \\
\hline & & \multirow[b]{2}{*}{ MD } & \multirow[b]{2}{*}{$\mathrm{SD}$} & \multirow[b]{2}{*}{$\mathrm{SE}$} & \multicolumn{2}{|c|}{$95 \% \mathrm{CI}$} & & & \\
\hline & & & & & $\begin{array}{l}\text { Lower } \\
\text { Limit }\end{array}$ & $\begin{array}{l}\text { Upper } \\
\text { Limit }\end{array}$ & & & \\
\hline 1 & $1-2$ & -1.30 & 11.91 & 1.76 & -4.84 & 2.23 & -0.74 & 45 & .01 \\
\hline 2 & $1-3$ & -0.78 & 14.15 & 2.09 & -4.98 & 3.42 & -0.38 & 45 & .003 \\
\hline 3 & $2-3$ & 0.52 & 12.48 & 1.84 & -3.18 & 4.23 & 0.28 & 45 & .001 \\
\hline
\end{tabular}

The estimated marginal means of attitude graph illustrated that the attitude scores of the students in control group almost never changed. Those of the students in experimental group, whereas, changed over time. Their attitude scores were highest after the visit, and it appeared that their attitudes decreased one week later. However, students' attitudes were still significantly higher than those before the visit. This result suggested that METU SC is effective in changing $6^{\text {th }}$ graders' overall attitudes towards science positively (Figure 4.1). 
Estimated Marginal Means of Attitude

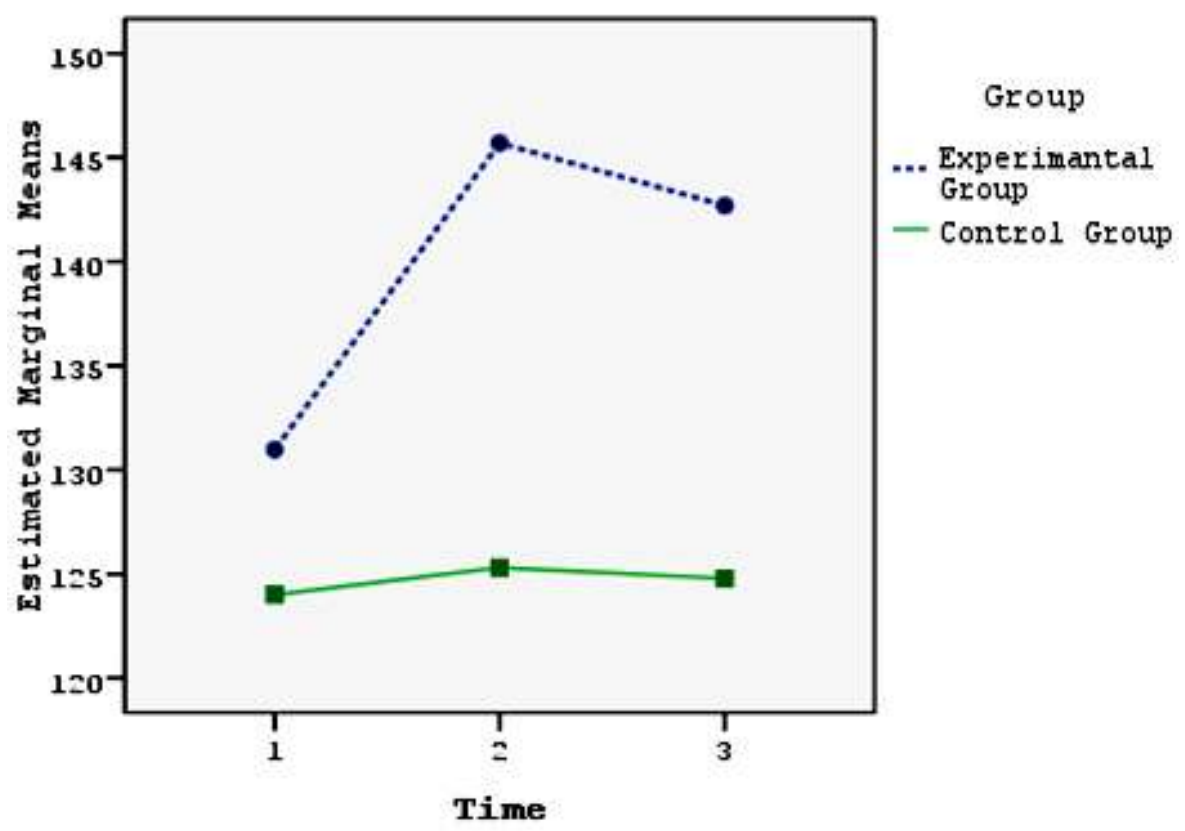

Figure 4.1: The Comparison of Estimated Marginal Means of Attitude across the Three Time Periods for Experimental and Control Group

\subsubsection{Sub- research question 1}

Sub-Research Hypothesis 1: Attitudes towards learning science in school

$\mathrm{H}_{11}$ : There is no change in mean scores of $6^{\text {th }}$ grade students' attitudes towards learning science in school across the three time periods.

$\mathrm{H}_{12}$ : There are no differences in mean scores of $6^{\text {th }}$ grade students' attitudes towards learning science in school between the experimental and control group across the three time periods. 
$\mathrm{H}_{13}$ : The change is not the same in mean scores of $6^{\text {th }}$ grade students' attitudes towards learning science in school across the three time periods for the different groups (experimental and control group).

The descriptive statistics for mean attitude scores of both groups across the three time periods can be seen in Table 4.6.

Table 4.6: Descriptive Statistics for Attitude Scores of Both Groups

\begin{tabular}{ccccc}
\hline & Group & M & SD & N \\
\hline Time 1 & Experimental & 23.91 & 4.60 & 46 \\
& Control & 22.65 & 4.79 & 46 \\
& Total & 23.28 & 4.71 & 92 \\
Time 2 & Experimental & 26.09 & 4.19 & 46 \\
& Control & 22.37 & 4.86 & 46 \\
& Total & 24.23 & 4.89 & 92 \\
Time 3 & Experimental & 25.61 & 3.86 & 46 \\
& Control & 22.17 & 4.94 & 46 \\
& Total & 23.89 & 4.73 & 92 \\
\hline
\end{tabular}

Box's M statistics had been violated (Box's M $=19, \mathrm{p}=.005<.050$ ), therefore Pillai's trace values were used instead of Wilks' Lambdas. The multivariate results revealed that there was no significant main effect for time [Pillai's trace $=.04$, $\mathrm{F}(2,89)=2.08, \mathrm{p}=.131, \eta^{2}=.04$ indicating small effect size (Cohen, 1988 as cited in Pallant, 2005) (see Table 4.7)]. Bonferroni pairwise comparisons result for time revealed that there was no significant difference between the mean attitude scores towards learning science in school over time (Time 1: $\mathrm{M}=23.28, \mathrm{SE}=.49$; Time 2: $\mathrm{M}=24.23, \mathrm{SE}=.47$; Time 3: $\mathrm{M}=23.89, \mathrm{SE}=.46$ ).

A significant group-by-time interaction effect was obtained [Pillai's trace $=.07$, $\mathrm{F}(2,89)=3.38, \mathrm{p}=.038, \eta^{2}=.07$ indicating moderate effect size (Cohen, 1988 as cited in Pallant, 2005) (see Table 4.7)]. This result revealed that the change in 
mean attitude scores towards learning science in school over time is not same for both groups.

A significant main effect for group was obtained, $F(1,90)=12.10, p=.001<.050$, $\eta^{2}=.12$ indicating a moderate effect (Cohen, 1988 as cited in Pallant, 2005) (see Table 4.7). Bonferroni pairwise comparisons result for group revealed that there was a significant difference in mean attitude scores towards learning science in school between the experimental $(\mathrm{M}=25.20, \mathrm{SE}=.57)$ and the control group $(\mathrm{M}=22.40, \mathrm{SE}=.57)$.

Table 4.7: Multivariate Test Result

\begin{tabular}{ccccc}
\hline Effect & $\begin{array}{c}\text { Pillai's } \\
\text { Trace }\end{array}$ & $\mathrm{F}^{\mathrm{a}}$ & $\eta 2$ & $\begin{array}{c}\text { Observed } \\
\text { Power }\end{array}$ \\
\hline Time & .04 & 2.08 & .04 & .42 \\
Time $^{*}$ group & .07 & $3.38^{*}$ & .07 & .62 \\
\hline
\end{tabular}
Note. ${ }^{\mathrm{a} M u l t i v a r i a t e} \mathrm{df}=2,89 .{ }^{*} \mathrm{p}<.05,{ }^{* *} \mathrm{p}<.001$.

In the lights of information given above, while $\mathrm{H}_{12}$ was rejected, $\mathrm{H}_{11}$ and $\mathrm{H}_{13}$ were failed to reject. Besides, in order to determine the change in mean attitude scores of students in both groups over time, paired t-tests were conducted.

\section{Paired T-test for Experimental Group}

There was a significant increase in mean attitude scores from Time $1(\mathrm{M}=23.91$, $\mathrm{SD}=4.60)$ to Time $2(\mathrm{M}=26.09, \mathrm{SD}=4.19), \mathrm{t}(45)=-2.71, \mathrm{p}=.010, \eta^{2}=.14$ indicating large effect (Cohen, 1988 as cited in Pallant, 2005). However, there was no significant difference in mean attitude scores between the Time $1(\mathrm{M}=23.91$, $\mathrm{SD}=4.60)$ and Time $3(\mathrm{M}=25.61, \mathrm{SD}=3.86), \mathrm{t}(45)=-2.35, \mathrm{p}=.023, \eta^{2}=.11$ indicating moderate effect (Cohen, 1988 as cited in Pallant, 2005); Time 2 (M 
$=26.09, \mathrm{SD}=4.19)$ and Time $3\left(\mathrm{M}=25.61, \mathrm{SD}=3.86, \mathrm{t}(45)=-.95, \mathrm{p}=.346, \eta^{2}=.02\right.$ indicating small effect (Cohen, 1988 as cited in Pallant).

Table 4.8: Paired T-test Results for Experimental Group

\begin{tabular}{|c|c|c|c|c|c|c|c|c|c|}
\hline \multirow[b]{3}{*}{ Pair } & \multirow[b]{3}{*}{ Time } & \multicolumn{5}{|c|}{ Paired Differences } & \multirow[b]{3}{*}{$\mathrm{t}$} & \multirow[b]{3}{*}{ df } & \multirow[b]{3}{*}{$\eta 2$} \\
\hline & & \multirow[b]{2}{*}{ MD } & \multirow[b]{2}{*}{ SD } & \multirow[b]{2}{*}{$\mathrm{SE}$} & \multicolumn{2}{|c|}{$95 \%$ CI } & & & \\
\hline & & & & & $\begin{array}{l}\text { Lower } \\
\text { Limit }\end{array}$ & $\begin{array}{l}\text { Upper } \\
\text { Limit }\end{array}$ & & & \\
\hline 1 & $1-2$ & -2.17 & 5.44 & 0.80 & -3.79 & -0.56 & $-2.71 *$ & 45 & .14 \\
\hline 2 & $1-3$ & -1.70 & 4.88 & 0.72 & -3.15 & -0.25 & -2.35 & 45 & .11 \\
\hline 3 & $2-3$ & 0.48 & 3.40 & 0.50 & -0.53 & 1.49 & .95 & 45 & .02 \\
\hline
\end{tabular}

\section{Paired T-test for Control Group}

There were no significant differences in mean attitude scores over time. There was no significant increase in mean attitude scores from Time $1(\mathrm{M}=22.65, \mathrm{SD}=4.79)$ to Time $2(\mathrm{M}=22.37, \mathrm{SD}=4.86), \mathrm{t}(45)=.56, \mathrm{p}=.578, \eta^{2}=.01$ indicating small effect (Cohen, 1988 as cited in Pallant, 2005). Similarly, there was no significant difference in mean attitude scores between Time $1(\mathrm{M}=22.65, \mathrm{SD}=4.79)$ and Time $3(\mathrm{M}=22.17, \mathrm{SD}=4.94), \mathrm{t}(45)=.72, \mathrm{p}=.475, \eta^{2}=.01$ indicating small effect (Cohen, 1988 as cited in Pallant, 2005). In a similar way, there was no significant difference in mean attitude scores between Time $2(\mathrm{M}=22.37, \mathrm{SD}=4.86)$ and Time $3(\mathrm{M}=22.17, \mathrm{SD}=4.94), \mathrm{t}(45)=.47, \mathrm{p}=.638, \eta^{2}=.01$ indicating small effect size (Cohen, 1988 as cited in Pallant, 2005). 
Table 4.9: Paired T-test Results for Control Group

\begin{tabular}{|c|c|c|c|c|c|c|c|c|c|}
\hline \multirow[b]{3}{*}{ Pair } & \multirow[b]{3}{*}{ Time } & \multicolumn{5}{|c|}{ Paired Differences } & \multirow[b]{3}{*}{$\mathrm{T}$} & \multirow[b]{3}{*}{ df } & \multirow[b]{3}{*}{$\eta 2$} \\
\hline & & \multirow[b]{2}{*}{ MD } & \multirow[b]{2}{*}{ SD } & \multirow[b]{2}{*}{$\mathrm{SE}$} & \multicolumn{2}{|c|}{$95 \% \mathrm{CI}$} & & & \\
\hline & & & & & $\begin{array}{l}\text { Lower } \\
\text { Limit }\end{array}$ & $\begin{array}{l}\text { Upper } \\
\text { Limit }\end{array}$ & & & \\
\hline 1 & $1-2$ & 0.28 & 3.42 & 0.50 & -0.73 & 1.30 & 0.56 & 45 & .01 \\
\hline 2 & $1-3$ & 0.48 & 4.50 & 0.66 & -0.86 & 1.81 & 0.72 & 45 & .01 \\
\hline 3 & $2-3$ & 0.20 & 2.80 & 0.41 & -0.64 & 1.03 & 0.47 & 45 & .01 \\
\hline
\end{tabular}

The estimated marginal means of attitude graph illustrated that the mean attitude scores of the students in control group decreased over time. Those of the students in experimental group, whereas, fluctuated slightly. Their mean attitude scores were highest after the visit, and it appeared that those decreased one week later. This result suggested that there is a significant impact of METU SC on changing students' attitudes towards learning science in school in positive way. However, students' mean attitude scores were not still significantly higher one week later than those before the visit. This result revealed that METU SC is not effective in changing students' attitudes towards learning science in school positively due to the fact that the impact is temporary (Figure 4.2). 
Estimated Marginal Means of Attitude

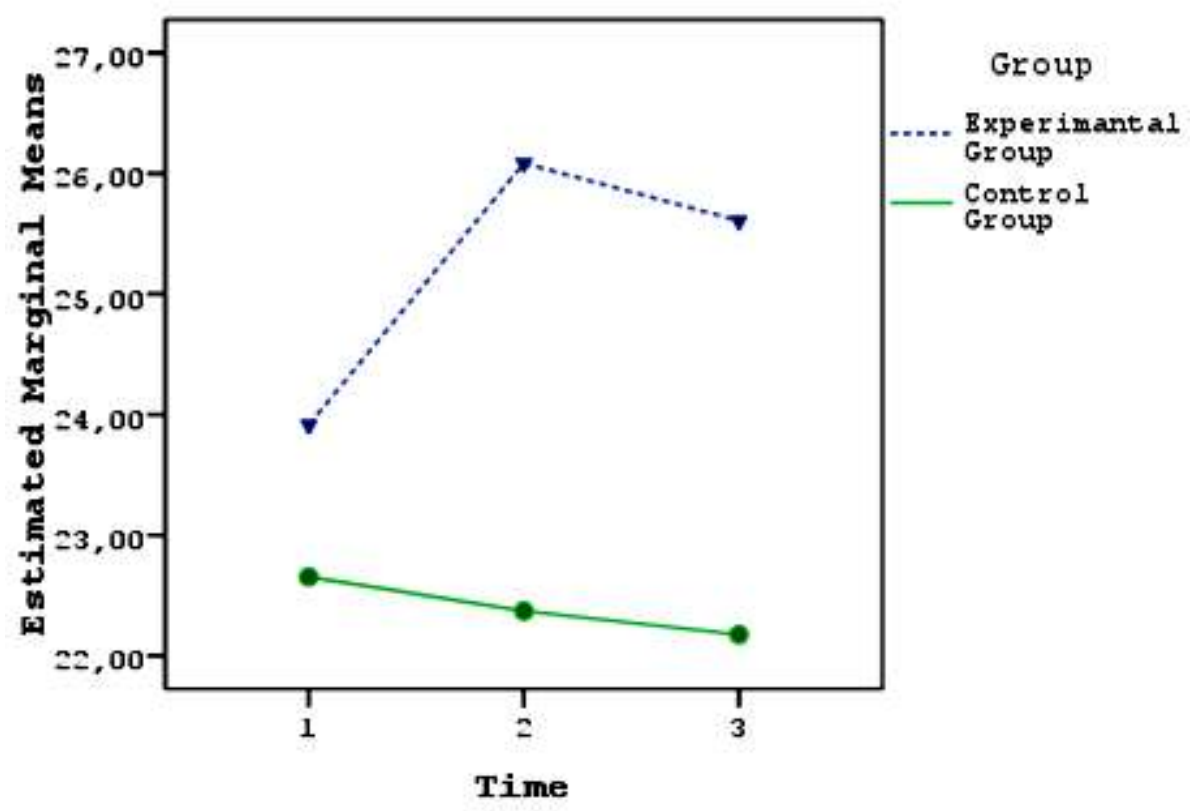

Figure 4.2: The Comparison of Estimated Marginal Means of Attitude towards Learning Science in School across the Three Time Periods for Experimental and Control Group

\subsubsection{Sub- research question 2}

Sub-Research Hypothesis 2: Attitudes towards self-concept in school science

$\mathrm{H}_{21}$ : There is no change in mean scores of $6^{\text {th }}$ grade students' attitudes towards self-concept in school science across the three time periods.

$\mathrm{H}_{22}$ : There are no differences in mean scores of $6^{\text {th }}$ grade students' attitudes towards self-concept in school science between the experimental and control group across the three time periods. 
$\mathrm{H}_{23}$ : The change is not the same in mean scores of $6^{\text {th }}$ grade students' attitudes towards self-concept in school science across the three time periods for the different groups (experimental and control group).

The descriptive statistics for mean attitude scores of both groups across the three time periods can be seen in Table 4.10.

Table 4.10: Descriptive Statistics for Attitude Scores of Both Groups

\begin{tabular}{ccccc}
\hline & Group & M & SD & N \\
\hline Time 1 & Experimental & 25.59 & 5.26 & 46 \\
& Control & 23.52 & 5.70 & 46 \\
& Total & 24.55 & 5.55 & 92 \\
Time 2 & Experimental & 29.07 & 5.41 & 46 \\
& Control & 24.30 & 5.63 & 46 \\
& Total & 26.68 & 5.99 & 92 \\
Time 3 & Experimental & 27.93 & 5.96 & 46 \\
& Control & 24.24 & 6.24 & 46 \\
& Total & 26.09 & 6.35 & 92 \\
\hline
\end{tabular}

Mauchly's test indicated that the assumption of sphericity had not been violated $\left[\chi^{2}(2)=.387, p=.824>.050\right]$; therefore sphericity assumed $\mathrm{F}$ test results for time and group were used. A mixed-model analysis of variance revealed that the main effect for time was significant, $\mathrm{F}(2,180)=12.83, \mathrm{p}=.000<.050, \eta^{2}=.12$ indicating a moderate effect (Cohen, 1988 as cited in Pallant, 2005) (see Table 4.11). Bonferroni pairwise comparisons result for time revealed that there was a significant increase in mean attitude scores from Time $1(\mathrm{M}=24.55, \mathrm{SE}=.57)$ to Time $2(\mathrm{M}=26.69, \mathrm{SE}=.58)$. Similarly, there was a significant difference in mean attitude scores between Time $1(\mathrm{M}=24.55, \mathrm{SE}=.57)$ and Time $3(\mathrm{M}=26.09$, $\mathrm{SE}=.64)$. Nonetheless, there was no significant difference in mean attitude scores between the Time $2(\mathrm{M}=26.68, \mathrm{SE}=.58)$ and Time $3(\mathrm{M}=26.09, \mathrm{SE}=.64)$.

A significant time*group interaction effect was also obtained, $F(2,180)=4.90$, $\mathrm{p}=.001<.050, \eta^{2}=.05$ indicating small effect (Cohen, 1988 as cited in Pallant, 
2005) (see Table 4.11). This result revealed that the change in mean attitude scores towards self-concept in school science across the three time periods is not same for both experimental and control groups.

A significant main effect for group was obtained, $F(1,90)=10.54, p=.000<.050$, $\eta^{2}=.11$ indicating a moderate effect (Cohen, 1988 as cited in Pallant, 2005) (see Table 4.11). Bonferroni pairwise comparisons result for group revealed that there was a significant difference in mean attitude scores towards self-concept in school science over time between the experimental $(\mathrm{M}=27.53, \mathrm{SE}=.76)$ and the control groups $(\mathrm{M}=24.02, \mathrm{SE}=.76)$.

Table 4.11: Analysis of Variance Results for Effects

\begin{tabular}{cccccc}
\hline Source & SS & df & MS & F & $\eta 2$ \\
\hline Between subjects & & & & & \\
Group & 282.92 & 1.00 & 282.92 & $10.54^{* *}$ & .11 \\
Error & $2,414.66$ & 90.00 & 26.83 & & \\
Within Subjects & & & & & \\
Time & 222.18 & 2.00 & 111.09 & $12.83^{* *}$ & .12 \\
Time*Group & 84.79 & 2.00 & 42.39 & $4.90^{*}$ & .05 \\
Error & $1,558.36$ & 180.00 & 8.66 & & \\
\hline Note. ${ }^{*} \mathrm{p}<.05,{ }^{* *} \mathrm{p}<.001$. & & & & &
\end{tabular}

In the lights of information given above, while $\mathrm{H}_{21}$ and $\mathrm{H}_{22}$ were rejected, $\mathrm{H}_{23}$ was failed to reject. Moreover, in order to determine the change in mean attitude scores of students in both groups over time, paired t-tests were conducted.

\section{Paired T-test for Experimental Group}

There was a significant increase in mean attitude scores from Time $1(\mathrm{M}=25.59$, $\mathrm{SD}=5.26)$ to Time $2(\mathrm{M}=29.07, \mathrm{SD}=5.41), \mathrm{t}(45)=-4.42, \mathrm{p}=.000, \eta^{2}=.30$ indicating very large effect (Cohen, 1988 as cited in Pallant, 2005). Similarly, there was a significant difference in mean attitude scores between Time $1(\mathrm{M}=25.59$, 
$\mathrm{SD}=5.26)$ and Time $3(\mathrm{M}=27.93, \mathrm{SD}=5.96), \mathrm{t}(45)=-3.84, \mathrm{p}=.000, \eta^{2}=.24$

indicating very large effect (Cohen, 1988 as cited in Pallant, 2005). Nevertheless, there was no significant difference in mean attitude scores between Time 2 $(\mathrm{M}=29.07, \mathrm{SD}=5.41)$ and Time $3(\mathrm{M}=27.93, \mathrm{SD}=5.96), \mathrm{t}(45)=1.62, \mathrm{p}=.113$, $\eta^{2}=.06$ indicating moderate effect size (Cohen, 1988 as cited in Pallant, 2005).

Table 4.12: Paired T-test Results for Experimental Group

\begin{tabular}{|c|c|c|c|c|c|c|c|c|c|}
\hline \multirow[b]{3}{*}{ Pair } & \multirow[b]{3}{*}{ Time } & \multicolumn{5}{|c|}{ Paired Differences } & \multirow[b]{3}{*}{$\mathrm{T}$} & \multirow[b]{3}{*}{ df } & \multirow[b]{3}{*}{$\eta^{2}$} \\
\hline & & \multirow[b]{2}{*}{ MD } & \multirow[b]{2}{*}{$\mathrm{SD}$} & \multirow[b]{2}{*}{$\mathrm{SE}$} & \multicolumn{2}{|c|}{$95 \% \mathrm{CI}$} & & & \\
\hline & & & & & $\begin{array}{l}\text { Lower } \\
\text { Limit }\end{array}$ & $\begin{array}{l}\text { Upper } \\
\text { Limit }\end{array}$ & & & \\
\hline 1 & $1-2$ & -3.48 & 5.34 & 0.79 & -5.06 & -1.89 & $-4.42 * *$ & 45 & .30 \\
\hline 2 & $1-3$ & -2.35 & 4.14 & 0.61 & -3.58 & -1.12 & $-3.84 * *$ & 45 & .24 \\
\hline 3 & $2-3$ & 1.13 & 4.74 & 0.70 & -0.28 & 2.54 & 1.62 & 45 & .06 \\
\hline
\end{tabular}

\section{Paired T-test for Control Group}

There were no significant differences in mean attitude scores over time. There was no significant increase in attitude scores from Time $1(\mathrm{M}=23.52, \mathrm{SD}=5.70)$ to Time $2(\mathrm{M}=24.30, \mathrm{SD}=5.63), \mathrm{t}(45)=-1.85, \mathrm{p}=.071, \eta^{2}=.07$ indicating moderate effect (Cohen, 1988 as cited in Pallant, 2005). Similarly, there was no significant difference in mean attitude scores between Time $1(\mathrm{M}=23.52, \mathrm{SD}=5.70)$ and Time $3(\mathrm{M}=24.24, \mathrm{SD}=6.24), \mathrm{t}(45)=-1.17, \mathrm{p}=.248, \eta^{2}=.03$ indicating small effect (Cohen, 1988 as cited in Pallant, 2005). And also, there was no significant difference in mean attitude scores between Time $2(\mathrm{M}=24.30, \mathrm{SD}=5.63)$ and Time $3(\mathrm{M}=24.24, \mathrm{SD}=6.24), \mathrm{t}(45)=.14, \mathrm{p}=.891, \eta^{2}=.0004$ indicating very small effect size (Cohen, 1988 as cited in Pallant, 2005). 
Table 4.13: Paired T-test Results for Control Group

\begin{tabular}{|c|c|c|c|c|c|c|c|c|c|}
\hline \multirow[b]{3}{*}{ Pair } & \multirow[b]{3}{*}{ Time } & \multicolumn{5}{|c|}{ Paired Differences } & \multirow[b]{3}{*}{$\mathrm{t}$} & \multirow[b]{3}{*}{$\mathrm{df}$} & \multirow[b]{3}{*}{$\eta^{2}$} \\
\hline & & \multirow[b]{2}{*}{ MD } & \multirow[b]{2}{*}{ SD } & \multirow[b]{2}{*}{ SE } & \multicolumn{2}{|c|}{$95 \% \mathrm{CI}$} & & & \\
\hline & & & & & $\begin{array}{l}\text { Lower } \\
\text { Limit }\end{array}$ & $\begin{array}{l}\text { Upper } \\
\text { Limit }\end{array}$ & & & \\
\hline 1 & $1-2$ & -0.78 & 2.87 & 0.42 & -1.63 & 0.07 & -1.85 & 45 & .07 \\
\hline 2 & $1-3$ & -0.72 & 4.16 & 0.61 & -1.95 & 0.52 & -1.17 & 45 & .03 \\
\hline 3 & $2-3$ & 0.07 & 3.21 & 0.47 & -0.89 & 1.02 & 0.14 & 45 & .0004 \\
\hline
\end{tabular}

The estimated marginal means of attitude graph illustrated that the attitude scores of the students in control group almost never changed. Those of the students in experimental group, whereas, changed over the time. Their attitude scores were highest after the visit, and it appeared one week later that their attitudes decreased. However, those were still significantly higher than those before the visit. This result suggested that METU SC is effective in changing students' attitudes towards self-concept in school science positively (Figure 4.3). 


\section{Estimated Marginal Means of Attitude}

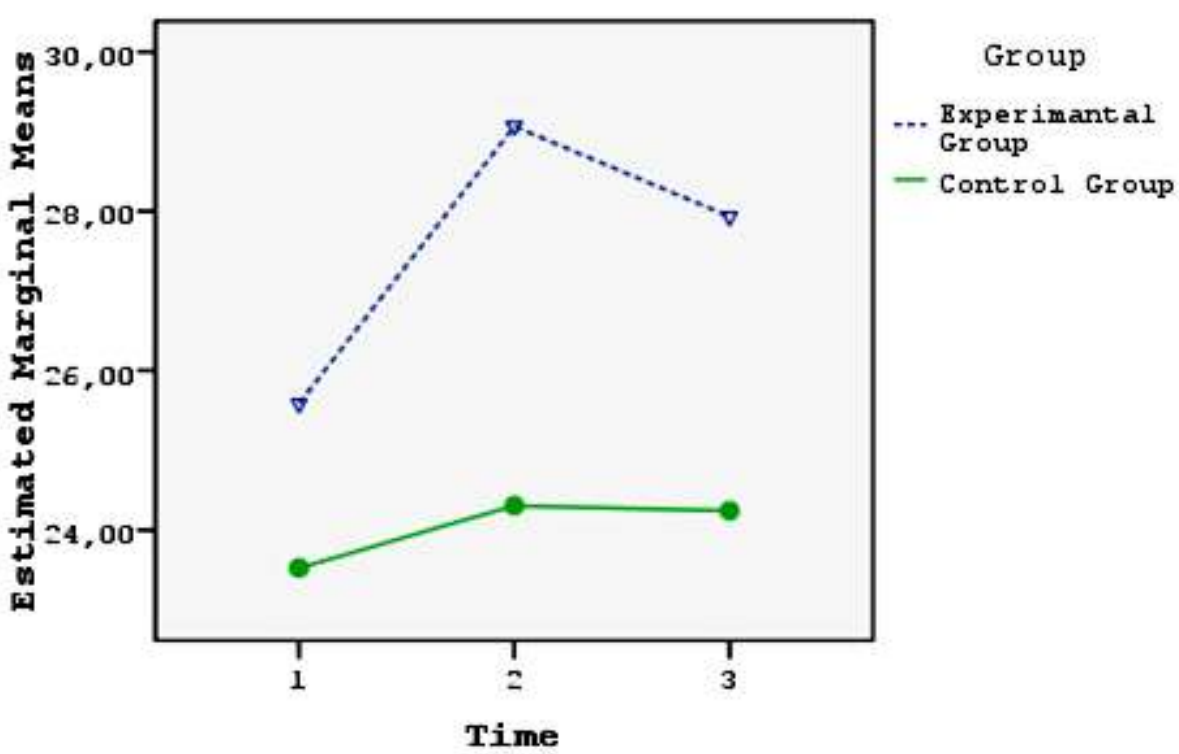

Figure 4.3: The Comparison of Estimated Marginal Means of Attitude towards Self-Concept in School Science across the Three Time Periods for Experimental and Control Group

\subsubsection{Sub- research question 3}

Sub-Research Hypothesis 3: Attitudes towards practical work in school science

$\mathrm{H}_{31}$ : There is no change in mean scores of $6^{\text {th }}$ grade students' attitudes towards practical work in school science across the three time periods.

$\mathrm{H}_{32}$ : There are no differences in mean scores of $6^{\text {th }}$ grade students' attitudes towards practical work in school science between the experimental and control group across the three time periods. 
$\mathrm{H}_{33}$ : The change is not the same in mean scores of $6^{\text {th }}$ grade students' attitudes towards practical work in school science across the three time periods for the different groups (experimental and control group).

The descriptive statistics for mean attitude scores of both groups across the three time periods are provided in Table 4.14.

Table 4.14: Descriptive Statistics for Attitude Scores of Both Groups

\begin{tabular}{ccccc}
\hline & Group & M & SD & N \\
\hline Time 1 & Experimental & 25.33 & 5.80 & 46 \\
& Control & 24.02 & 5.72 & 46 \\
& Total & 24.67 & 5.76 & 92 \\
Time 2 & Experimental & 27.37 & 3.21 & 46 \\
& Control & 23.96 & 5.02 & 46 \\
& Total & 25.66 & 4.53 & 92 \\
Time 3 & Experimental & 26.26 & 5.14 & 46 \\
& Control & 24.00 & 5.45 & 46 \\
& Total & 25.13 & 5.39 & 92 \\
\hline
\end{tabular}

Mauchly's test indicated that the assumption of sphericity had not been violated $\left[\chi^{2}(2)=.165, p=.921>.050\right]$; therefore sphericity assumed $\mathrm{F}$ test results for time and group were used. A mixed-model analysis of variance revealed that the main effect for time was not significant, $F(2,180)=2.31, \mathrm{p}=.102<.050, \eta^{2}=.03$ indicating small effect (Cohen, 1988 as cited in Pallant, 2005) (see Table 4.15). Bonferroni pairwise comparisons result for time revealed that there was no significant difference in mean attitude scores between Time $1(\mathrm{M}=24.67, \mathrm{SE}=.60)$ and Time $2(\mathrm{M}=25.66, \mathrm{SE}=.44)$. There was no significant difference in mean attitude scores between the Time $2(\mathrm{M}=25.66, \mathrm{SE}=.44)$ and Time $3(\mathrm{M}=25.13$, $\mathrm{SE}=.55)$. Similarly, there was no significant difference in mean attitude scores between Time $1(\mathrm{M}=24.67, \mathrm{SE}=.60)$ and Time $3(\mathrm{M}=25.13, \mathrm{SE}=.55)$.

A non-significant time* group interaction effect was obtained, $F(2,180)=2.63$, $\mathrm{p}=.075>.050, \eta^{2}=.03$ indicating small effect (Cohen, 1988 as cited in Pallant, 
2005) (see Table 4.15). This result suggested that the overall change in mean attitude scores over time is statistically same for experimental and control groups.

A significant main effect for group was obtained, $F(1,90)=6.27, p=.014<.050$, $\eta^{2}=.07$ indicating a moderate effect (Cohen, 1988 as cited in Pallant, 2005) (see Table 4.15). This result showed that there was a significant difference in mean attitude scores towards practical work in school science between the experimental $(\mathrm{M}=26.32, \mathrm{SE}=.66)$ and the control group $(\mathrm{M}=23.99, \mathrm{SE}=.66)$.

Table 4.15: Analysis of Variance Results for Effects

\begin{tabular}{cccccc}
\hline Source & SS & df & MS & F & $\eta^{2}$ \\
\hline Between subjects & & & & & \\
Group & 124.45 & 1.00 & 124.45 & 6.27 & 0.07 \\
Error & $1,784.988$ & 90 & 19.833 & & \\
Within Subjects & & & & & \\
Time & 45.09 & 2.00 & 22.55 & 2.31 & 0.03 \\
Time*Group & 51.28 & 2.00 & 25.64 & 2.63 & 0.03 \\
Error & $1,753.62$ & 180.00 & 9.74 & & \\
\hline Note. ${ }^{*}<<.05,{ }^{* *} \mathrm{p}<.001$. & & & & &
\end{tabular}

In the lights of information given above, while $\mathrm{H}_{32}$ was rejected, $\mathrm{H}_{31}$ and $\mathrm{H}_{33}$ were failed to reject. In addition, in order to determine the change in mean attitude scores of students in both groups over time, paired t-tests were conducted.

\section{Paired T-test for Experimental Group}

There was a significant increase in mean attitude scores from Time $1(\mathrm{M}=25.33$, $\mathrm{SD}=5.80)$ to Time $2(\mathrm{M}=27.37, \mathrm{SD}=3.21), \mathrm{t}(45)=-2.76, \mathrm{p}=.008, \eta^{2}=.15$ indicating large effect (Cohen, 1988 as cited in Pallant, 2005). Nevertheless, there was no significant difference in mean attitude scores between Time $1(\mathrm{M}=25.33$, $\mathrm{SD}=5.80)$ and Time $3(\mathrm{M}=26.26, \mathrm{SD}=5.14), \mathrm{t}(45)=-1.41, \mathrm{p}=.165, \eta^{2}=.04$ indicating small effect (Cohen, 1988 as cited in Pallant, 2005). Furthermore, there 
was no significant difference in mean attitude scores between Time $2(\mathrm{M}=27.37$, $\mathrm{SD}=3.21)$ and Time $3(\mathrm{M}=26.26, \mathrm{SD}=5.14), \mathrm{t}(45)=1.55, \mathrm{p}=.128, \eta^{2}=.05$ indicating small effect size (Cohen, 1988 as cited in Pallant, 2005).

Table 4.16: Paired T-test Results for Experimental Group

\begin{tabular}{|c|c|c|c|c|c|c|c|c|c|}
\hline \multirow[b]{3}{*}{ Pair } & \multirow[b]{3}{*}{ Time } & \multicolumn{5}{|c|}{ Paired Differences } & \multirow[b]{3}{*}{$\mathrm{t}$} & \multirow[b]{3}{*}{$\mathrm{df}$} & \multirow[b]{3}{*}{$\eta^{2}$} \\
\hline & & \multirow[b]{2}{*}{ MD } & \multirow[b]{2}{*}{ SD } & \multirow[b]{2}{*}{ SE } & \multicolumn{2}{|c|}{$95 \% \mathrm{CI}$} & & & \\
\hline & & & & & $\begin{array}{c}\text { Lower } \\
\text { Limit }\end{array}$ & $\begin{array}{l}\text { Upper } \\
\text { Limit }\end{array}$ & & & \\
\hline 1 & $1-2$ & -2.04 & 5.02 & 0.74 & -3.53 & -0.55 & $-2.76^{*}$ & 45 & .15 \\
\hline 2 & $1-3$ & -0.93 & 4.49 & 0.66 & -2.27 & 0.40 & -1.41 & 45 & .04 \\
\hline 3 & $2-3$ & 1.11 & 4.85 & 0.72 & -0.33 & 2.55 & 1.55 & 45 & .05 \\
\hline
\end{tabular}

\section{Paired T-test for Control Group}

There were no significant differences in mean attitude scores over time. There was no significant increase in mean attitude scores from Time $1(\mathrm{M}=24.02, \mathrm{SD}=5.72)$ to Time $2(\mathrm{M}=23.96, \mathrm{SD}=5.02), \mathrm{t}(45)=.12, \mathrm{p}=.907, \eta^{2}=.0003$ indicating very small effect (Cohen, 1988 as cited in Pallant, 2005). Similarly, there was no significant difference in mean attitude scores between Time $1(\mathrm{M}=24.02, \mathrm{SD}=5.72)$ and Time $3(\mathrm{M}=24.00, \mathrm{SD}=5.45), \mathrm{t}(45)=.04, \mathrm{p}=.972, \eta^{2}=.00004$ indicating very small effect (Cohen, 1988 as cited in Pallant, 2005). In a similar way, there was no significant difference in mean attitude scores between Time $2(M=23.96$, $\mathrm{SD}=5.02)$ and Time $3(\mathrm{M}=24.00, \mathrm{SD}=5.45), \mathrm{t}(45)=-.07, \mathrm{p}=.943, \eta^{2}=.0001$ indicating very small effect size (Cohen, 1988 as cited in Pallant, 2005). 
Table 4.17: Paired T-test Results for Control Group

\begin{tabular}{|c|c|c|c|c|c|c|c|c|c|}
\hline \multirow[b]{3}{*}{ Pair } & \multirow[b]{3}{*}{ Time } & \multicolumn{5}{|c|}{ Paired Differences } & \multirow[b]{3}{*}{$\mathrm{T}$} & \multirow[b]{3}{*}{ df } & \multirow[b]{3}{*}{$\eta^{2}$} \\
\hline & & \multirow[b]{2}{*}{ MD } & \multirow[b]{2}{*}{ SD } & \multirow[b]{2}{*}{ SE } & \multicolumn{2}{|c|}{$95 \% \mathrm{CI}$} & & & \\
\hline & & & & & $\begin{array}{c}\text { Lower } \\
\text { Limit }\end{array}$ & $\begin{array}{l}\text { Upper } \\
\text { Limit }\end{array}$ & & & \\
\hline 1 & $1-2$ & 0.07 & 3.78 & 0.56 & -1.06 & 1.19 & .12 & 45 & .0003 \\
\hline 2 & $1-3$ & 0.02 & 4.14 & 0.61 & -1.21 & 1.25 & .04 & 45 & .00004 \\
\hline 3 & $2-3$ & -0.04 & 4.07 & 0.60 & -1.25 & 1.16 & -.07 & 45 & .0001 \\
\hline
\end{tabular}

The estimated marginal means of attitude graph illustrated that the mean attitude scores of the students in control group never changed over time. Those of the students in experimental group, whereas, fluctuated slightly over the time. Their mean attitude scores were highest after the visit, and one week later it appeared that their mean attitudes scores decreased. This result suggested that there was an impact of METU SC on changing students' attitudes towards practical work in school science positively. However, students' mean attitude scores at one week later were not still significantly higher than those before the visit. This result suggested that METU SC is not effective in changing students' attitudes towards practical work in school science positively due to the fact that this impact is temporary (Figure 4.4). 
Est imated Karginal Keans of Attitude

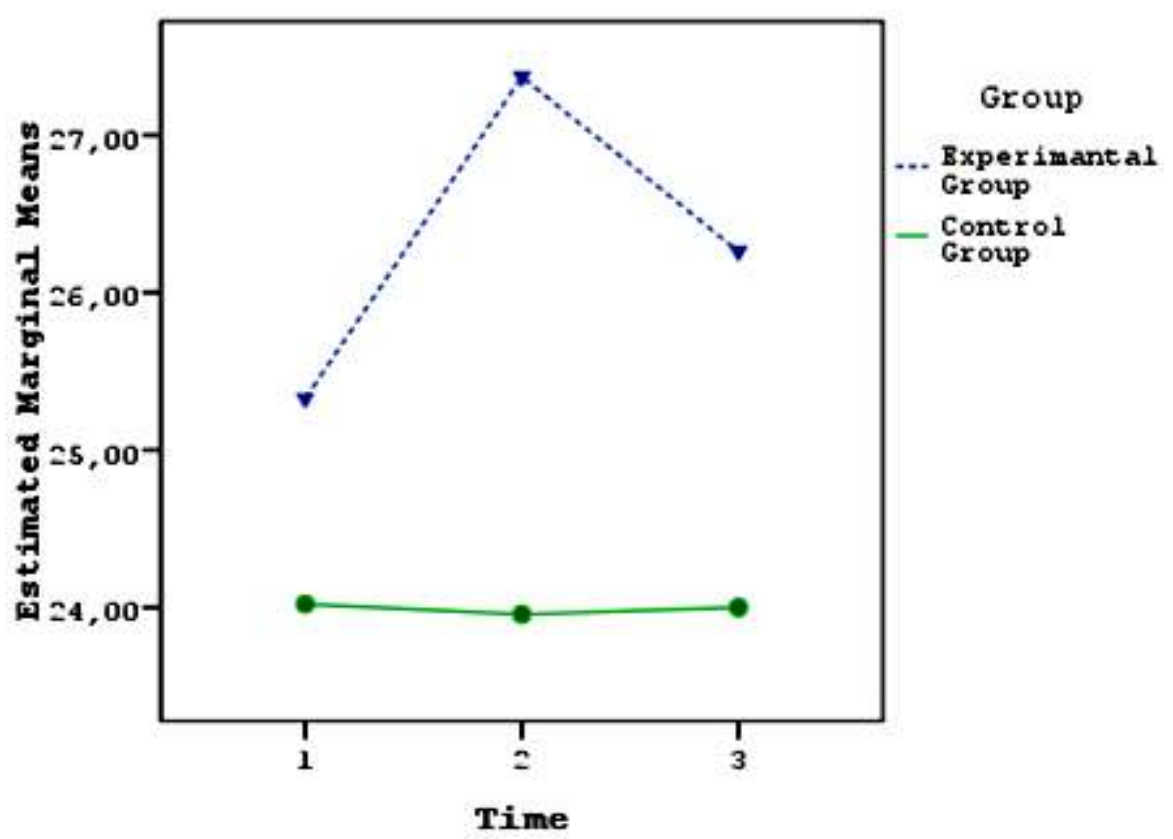

Figure 4.4: The Comparison of Estimated Marginal Means of Attitude towards Practical Work in School Science across the Three Time Periods for Experimental and Control Group

\subsubsection{Sub- research question 4}

Sub- Research Hypothesis 4: Attitudes towards science outside of school

$\mathrm{H}_{41}$ : There is no change in mean scores of $6^{\text {th }}$ grade students' attitudes towards science outside of school across the three time periods.

$\mathrm{H}_{42}$ : There are no differences in mean scores of $6^{\text {th }}$ grade students' attitudes towards science outside of school between the experimental and control group across the three time periods. 
$\mathrm{H}_{43}$ : The change is not the same in mean scores of $6^{\text {th }}$ grade students' attitudes towards science outside of school across the three time periods for the different groups (experimental and control group).

The descriptive statistics for mean attitude scores of both groups across the three time periods are shown in Table 4.18.

Table 4.18: Descriptive Statistics for Attitude Scores of Both Groups

\begin{tabular}{ccccc}
\hline & Group & $\mathrm{M}$ & $\mathrm{SD}$ & $\mathrm{N}$ \\
\hline Time 1 & Experimental & 24.41 & 5.03 & 46 \\
& Control & 23.13 & 5.66 & 46 \\
& Total & 23.77 & 5.36 & 92 \\
Time 2 & Experimental & 27.52 & 3.30 & 46 \\
& Control & 23.76 & 4.42 & 46 \\
& Total & 25.64 & 4.32 & 92 \\
Time 3 & Experimental & 27.09 & 3.63 & 46 \\
& Control & 23.09 & 5.82 & 46 \\
& Total & 25.09 & 5.23 & 92 \\
\hline
\end{tabular}

Mauchly's test indicated that the assumption of sphericity had not been violated $\left[\chi^{2}(2)=5.14, p=.076>.050\right]$; therefore sphericity assumed $\mathrm{F}$ test results for time and group were used. A mixed-model analysis of variance revealed that the main effect for time was significant, $\mathrm{F}(2,180)=9.90, \mathrm{p}=.000<.050, \eta^{2}=.10$ indicating moderate effect (Cohen, 1988 as cited in Pallant, 2005) (see Table 4.19).

Bonferroni pairwise comparisons result for time revealed that there was significant difference in mean attitude scores between Time $1(\mathrm{M}=23.77, \mathrm{SE}=.56)$ and Time 2 $(\mathrm{M}=25.64, \mathrm{SE}=.41)$. Similarly, there was also significant difference in mean attitude scores between the Time $1(\mathrm{M}=23.77, \mathrm{SE}=.56)$ and Time $3(\mathrm{M}=25.09$, $\mathrm{SD}=.51)$. Nonetheless, there was no significant difference in mean attitude scores between Time $2(\mathrm{M}=25.64, \mathrm{SE}=.41)$ and Time $3(\mathrm{M}=25.09, \mathrm{SD}=.51)$. 
A significant time*group interaction effect was also obtained, $F(2,180)=6.08$, $\mathrm{p}=.003<.050, \eta^{2}=.06$ indicating moderate effect (Cohen, 1988 as cited in Pallant, 2005) (see Table 4.19). This result revealed that the change is not the same in mean attitude scores towards science outside of school over time for both groups.

A significant main effect for group was also obtained, $F(1,90)=12.47$, $\mathrm{p}=.001<.050, \eta^{2}=.12$ indicating a moderate effect (Cohen, 1988 as cited in Pallant, 2005) (see Table 4.19). Bonferroni pairwise comparisons result for group revealed that there was a significant difference in mean attitude scores towards science outside of school between the experimental $(\mathrm{M}=26.34, \mathrm{SE}=.60)$ and the control group $(\mathrm{M}=23.33, \mathrm{SE}=.60)$.

Table 4.19: Analysis of Variance Results for Effects

\begin{tabular}{cccccc}
\hline Source & SS & df & MS & F & $\eta^{2}$ \\
\hline Between subjects & & & & & \\
Group & 209.00 & 1 & 209.00 & $12.47^{*}$ & .12 \\
Error & $1,508.44$ & 90 & 16.760 & & \\
Within Subjects & & & & & \\
Time & 169.66 & 2.00 & 84.83 & $9.90^{* *}$ & .10 \\
Time*Group & 104.14 & 2.00 & 52.07 & $6.08^{*}$ & .06 \\
Error & $1,542.20$ & 180.00 & 8.57 & & \\
\hline Note $*$ p $<05, * * p<001$ & & & &
\end{tabular}

Note. ${ }^{*} \mathrm{p}<.05,{ }^{* *} \mathrm{p}<.001$.

In the lights of information given above, while $\mathrm{H}_{41}$ and $\mathrm{H}_{42}$ were rejected, $\mathrm{H}_{43}$ was failed to reject. Furthermore, in order to determine the change in mean attitude scores of students in both groups over time, paired t-tests were conducted. 


\section{Paired T-test for Experimental Group}

There was a significant increase in mean attitude scores from Time $1(M=24.41$, $\mathrm{SD}=5.03)$ to Time $2(\mathrm{M}=27.52, \mathrm{SD}=3.30), \mathrm{t}(45)=-5.55, \mathrm{p}=.000, \eta^{2}=.41$ indicating very large effect (Cohen, 1988 as cited in Pallant, 2005). Besides, there was also significant difference in mean attitude scores between Time $1(\mathrm{M}=24.41$, $\mathrm{SD}=5.03)$ and Time $3(\mathrm{M}=27.09, \mathrm{SD}=3.63), \mathrm{t}(45)=-4.21, \mathrm{p}=.000, \eta^{2}=.28$ indicating very large effect (Cohen, 1988 as cited in Pallant, 2005). Nevertheless, there was no significant difference in mean attitude scores between Time 2 $(\mathrm{M}=27.52, \mathrm{SD}=3.30)$ and Time $3(\mathrm{M}=27.09, \mathrm{SD}=3.63), \mathrm{t}(45)=.90, \mathrm{p}=.375$, $\eta^{2}=.02$ indicating small effect size (Cohen, 1988 as cited in Pallant, 2005).

Table 4.20: Paired T-test Results for Experimental Group

\begin{tabular}{|c|c|c|c|c|c|c|c|c|c|}
\hline \multirow[b]{3}{*}{ Pair } & \multirow[b]{3}{*}{ Time } & \multicolumn{5}{|c|}{ Paired Differences } & \multirow[b]{3}{*}{$\mathrm{t}$} & \multirow[b]{3}{*}{ df } & \multirow[b]{3}{*}{$\eta^{2}$} \\
\hline & & \multirow[b]{2}{*}{ MD } & \multirow[b]{2}{*}{ SD } & \multirow[b]{2}{*}{$\mathrm{SE}$} & \multicolumn{2}{|c|}{$95 \% \mathrm{CI}$} & & & \\
\hline & & & & & $\begin{array}{l}\text { Lower } \\
\text { Limit }\end{array}$ & $\begin{array}{l}\text { Upper } \\
\text { Limit }\end{array}$ & & & \\
\hline 1 & $1-2$ & -3.11 & 3.80 & 0.56 & -4.24 & -1.98 & $-5.55 * *$ & 45 & .41 \\
\hline 2 & $1-3$ & -2.67 & 4.31 & 0.64 & -3.95 & -1.39 & $-4.21 * *$ & 45 & .28 \\
\hline 3 & $2-3$ & 0.43 & 3.29 & 0.49 & -0.54 & 1.41 & .90 & 45 & .02 \\
\hline
\end{tabular}

\section{Paired T-test for Control Group}

There were no significant differences in mean attitude scores over time. There was no significant increase in mean attitude scores from Time $1(\mathrm{M}=23.13, \mathrm{SD}=5.66)$ to Time $2(\mathrm{M}=23.76, \mathrm{SD}=4.42), \mathrm{t}(45)=-.94, \mathrm{p}=.351, \eta^{2}=.02$ indicating small effect (Cohen, 1988 as cited in Pallant, 2005). Similarly, there was no significant difference in mean attitude scores between Time $1(\mathrm{M}=23.13, \mathrm{SD}=5.66)$ and Time $3(\mathrm{M}=23.09, \mathrm{SD}=5.82), \mathrm{t}(45)=.06, \mathrm{p}=.951, \eta^{2}=.0001$ indicating very small effect (Cohen, 1988 as cited in Pallant, 2005). In a similar way, there was no 
significant difference in mean attitude scores between Time $2(\mathrm{M}=23.76$, $\mathrm{SD}=4.42)$ and Time $3(\mathrm{M}=23.09, \mathrm{SD}=5.82), \mathrm{t}(45)=1.14, \mathrm{p}=.261, \eta^{2}=.03$ indicating small effect size (Cohen, 1988 as cited in Pallant, 2005).

Table 4.21: Paired T-test Results for Control Group

\begin{tabular}{ccccccccccc}
\hline & & \multicolumn{9}{c}{ Paired Differences } \\
\cline { 3 - 7 } Pair & Time & MD & SD & SE & $\begin{array}{c}\text { Lower } \\
\text { Limit }\end{array}$ & $\begin{array}{c}\text { Upper } \\
\text { Limit }\end{array}$ & t & df & $\eta^{2}$ \\
\hline 1 & $1-2$ & -0.63 & 4.53 & 0.67 & -1.98 & 0.72 & -.94 & 45 & .02 \\
2 & $1-3$ & 0.04 & 4.73 & 0.70 & -1.36 & 1.45 & .06 & 45 & .0001 \\
3 & $2-3$ & 0.67 & 4.01 & 0.59 & -0.52 & 1.87 & 1.14 & 45 & .03 \\
\hline
\end{tabular}

The estimated marginal means of attitude graph illustrated that the mean attitude scores of the students in control group almost never changed over time. Those of the students in experimental group, whereas, fluctuated slightly over time. Their mean attitude scores were highest after the visit, and it appeared that their attitudes decreased one week later. However, those were still significantly higher than those before the visit. This result suggested that METU SC is effective in changing students' attitudes towards science outside of school positively (Figure 4.5). 
Estimated Marginal Means of Attitude

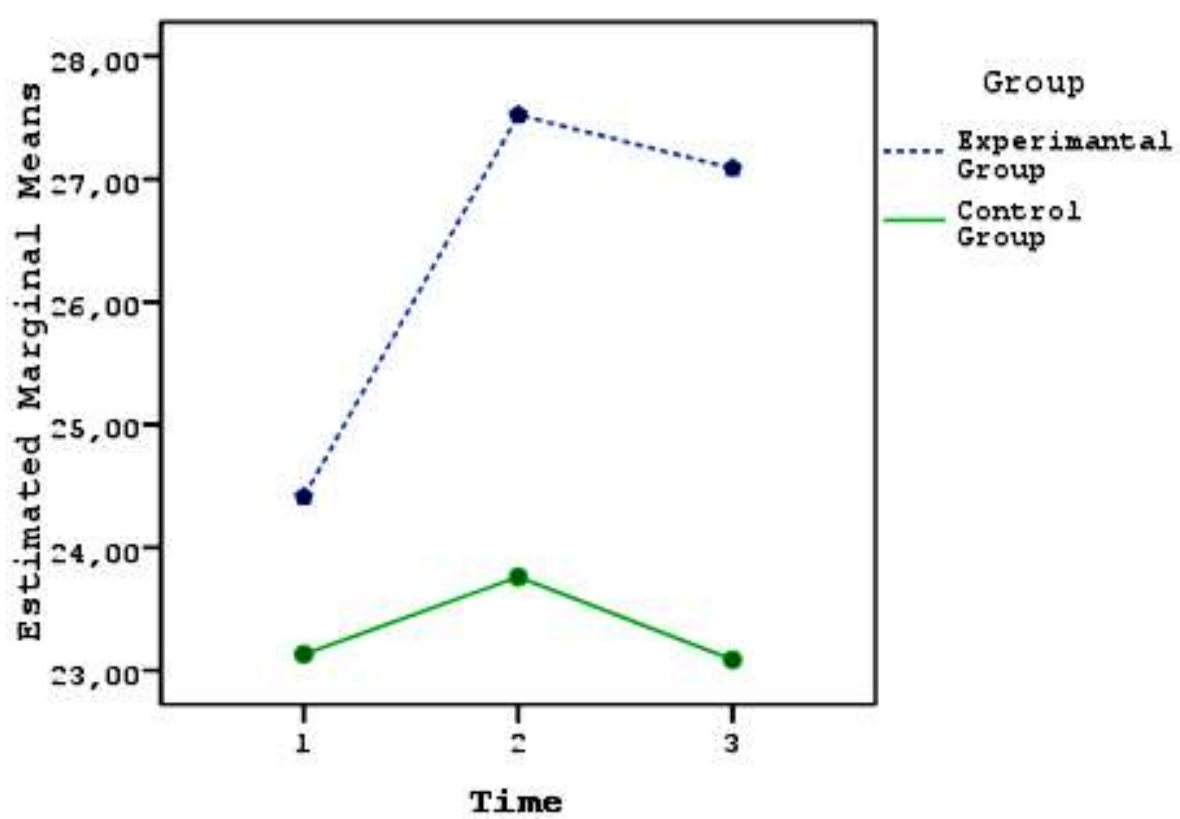

Figure 4.5: The Comparison of Estimated Marginal Means of Attitude towards Science Outside of School across the Three Time Periods for Experimental and Control Group

\subsubsection{Sub- research question 5}

Sub- Research Hypothesis 5: Attitudes towards future participation in science

$\mathrm{H}_{51}$ : There is no change in mean scores of $6^{\text {th }}$ grade students' attitudes towards future participation in science across the three time periods.

$\mathrm{H}_{52}$ : There are no differences in mean scores of $6^{\text {th }}$ grade students' attitudes towards future participation in science between the experimental and control group across the three time periods. 
$\mathrm{H}_{53}$ : The change is not the same in mean scores of $6^{\text {th }}$ grade students' attitudes towards future participation in science across the three time periods for the different groups (experimental and control group).

The descriptive statistics for mean attitude scores of both groups across the three time periods can be seen in Table 4.22 .

Table 4.22: Descriptive Statistics for Attitude Scores of Both Groups

\begin{tabular}{ccccc}
\hline & Group & $\mathrm{M}$ & $\mathrm{SD}$ & $\mathrm{N}$ \\
\hline Time 1 & Experimental & 15.17 & 3.64 & 46 \\
& Control & 14.02 & 4.48 & 46 \\
& Total & 14.60 & 4.10 & 92 \\
Time 2 & Experimental & 17.57 & 3.10 & 46 \\
& Control & 14.61 & 3.96 & 46 \\
& Total & 16.09 & 3.83 & 92 \\
Time 3 & Experimental & 17.26 & 3.40 & 46 \\
& Control & 14.98 & 4.59 & 46 \\
& Total & 16.12 & 4.18 & 92 \\
\hline
\end{tabular}

Mauchly's test indicated that the assumption of sphericity had not been violated $\left[\chi^{2}(2)=.34, p=.844>.050\right]$; therefore sphericity assumed $\mathrm{F}$ test results for time and group were used. A mixed-model analysis of variance revealed that the main effect for time was significant, $\mathrm{F}(2,180)=12.65, \mathrm{p}=.000<.050, \eta^{2}=.12$ indicating moderate effect (Cohen, 1988 as cited in Pallant, 2005) (see Table 4.23). Bonferroni pairwise comparisons result for time revealed that there was a significant difference in mean attitude scores between Time $1(\mathrm{M}=14.60, \mathrm{SE}=.43)$ and Time $2(\mathrm{M}=16.09, \mathrm{SE}=.37)$. Similarly, there was also significant difference in mean attitude scores between the Time $1(\mathrm{M}=14.60, \mathrm{SE}=.43)$ and Time 3 $(\mathrm{M}=16.12, \mathrm{SE}=.42)$. Nonetheless, there was no significant difference in mean attitude scores between Time $2(\mathrm{M}=16.09, \mathrm{SE}=.37)$ and Time $3(\mathrm{M}=16.12$, $\mathrm{SE}=.42)$. 
A significant time* group interaction effect was also obtained, $F(2,180)=3.48$, $\mathrm{p}=.033<.050, \eta^{2}=.04$ indicating small effect (Cohen, 1988 as cited in Pallant, 2005) (see Table 4.23). This result revealed that the change in mean attitude scores towards future participation in science across the three time periods was not the same for experimental and control groups.

A significant main effect for group was obtained, $\mathrm{F}(1,90)=9.06, \mathrm{p}=.003<.050$, $\eta^{2}=.09$ indicating a moderate effect (Cohen, 1988 as cited in Pallant, 2005) (see Table 4.23). Bonferroni pairwise comparisons result for group revealed that there was a significant difference in attitude scores towards future participation in science between the experimental $(\mathrm{M}=16.67, \mathrm{SE}=.50)$ and the control group $(\mathrm{M}=14.54, \mathrm{SE}=.50)$.

Table 4.23: Analysis of Variance Results for Effects

\begin{tabular}{cccccc}
\hline Source & SS & df & MS & F & $\eta^{2}$ \\
\hline Between subjects & & & & & \\
Group & 104.39 & 1.00 & 104.39 & $9.06^{*}$ & .09 \\
Error & $1,037.44$ & 90 & 11.53 & & \\
Within Subjects & & & & & \\
Time & 139.05 & 2.00 & 69.53 & $12.65^{* *}$ & .12 \\
Time*Group & 38.24 & 2.00 & 19.12 & $3.48^{*}$ & .04 \\
Error & 989.38 & 180.00 & 5.50 & & \\
\hline
\end{tabular}

Note. ${ }^{*} \mathrm{p}<.05,{ }^{* *} \mathrm{p}<.001$.

In the lights of information given above, while $\mathrm{H}_{51}$ and $\mathrm{H}_{52}$ were rejected, $\mathrm{H}_{53}$ was failed to reject. Besides, in order to determine the change in mean attitude scores of students in both groups over time, paired t-tests were conducted. 


\section{Paired T-test for Experimental Group}

There was a significant increase in mean attitude scores from Time $1(\mathrm{M}=15.17$, $\mathrm{SD}=3.64)$ to Time $2(\mathrm{M}=17.57, \mathrm{SD}=3.10), \mathrm{t}(45)=-4.20, \mathrm{p}=.000, \eta^{2}=.28$ indicating very large effect (Cohen, 1988 as cited in Pallant, 2005). Besides, there was also significant difference in mean attitude scores between Time $1(\mathrm{M}=15.17$, $\mathrm{SD}=3.64)$ and Time $3(\mathrm{M}=17.26, \mathrm{SD}=3.40), \mathrm{t}(45)=-4.09, \mathrm{p}=.000, \eta^{2}=.27$ indicating very large effect (Cohen, 1988 as cited in Pallant, 2005). Nevertheless, there was no significant difference in mean attitude scores between Time 2 $(\mathrm{M}=17.57, \mathrm{SD}=3.10)$ and Time $3(\mathrm{M}=17.26, \mathrm{SD}=3.40), \mathrm{t}(45)=.52, \mathrm{p}=.603$, $\eta^{2}=.006$ indicating small effect size (Cohen, 1988 as cited in Pallant, 2005).

Table 4.24: Paired T-test Results for Experimental Group

\begin{tabular}{|c|c|c|c|c|c|c|c|c|c|}
\hline \multirow[b]{3}{*}{ Pair } & \multirow[b]{3}{*}{ Time } & \multicolumn{5}{|c|}{ Paired Differences } & \multirow[b]{3}{*}{$\mathrm{t}$} & \multirow[b]{3}{*}{ df } & \multirow[b]{3}{*}{$\eta^{2}$} \\
\hline & & \multirow[b]{2}{*}{ MD } & \multirow[b]{2}{*}{$\mathrm{SD}$} & \multirow[b]{2}{*}{ SE } & \multicolumn{2}{|c|}{$95 \% \mathrm{CI}$} & & & \\
\hline & & & & & $\begin{array}{l}\text { Lower } \\
\text { Limit }\end{array}$ & $\begin{array}{l}\text { Upper } \\
\text { Limit }\end{array}$ & & & \\
\hline 1 & $1-2$ & -2.39 & 3.86 & 0.57 & -3.54 & -1.24 & $-4.20 * *$ & 45 & .28 \\
\hline 2 & $1-3$ & -2.09 & 3.46 & 0.51 & -3.11 & -1.06 & $-4.09 * *$ & 45 & .27 \\
\hline 3 & $2-3$ & 0.30 & 3.94 & 0.58 & -0.87 & 1.48 & .52 & 45 & .006 \\
\hline
\end{tabular}

\section{Paired T-test for Control Group}

There were no significant differences in mean attitude scores over time. There was no significant increase in mean attitude scores from Time $1(\mathrm{M}=14.02, \mathrm{SD}=4.48)$ to Time $2(\mathrm{M}=14.61, \mathrm{SD}=3.96), \mathrm{t}(45)=-1.48, \mathrm{p}=.146, \eta^{2}=.05$ indicating small effect (Cohen, 1988 as cited in Pallant, 2005). Similarly, there was no significant difference in mean attitude scores between Time $1(\mathrm{M}=14.02, \mathrm{SD}=4.48)$ and Time $3(\mathrm{M}=14.98, \mathrm{SD}=4.59), \mathrm{t}(45)=-2.19, \mathrm{p}=.034, \eta^{2}=.10$ indicating moderate effect (Cohen, 1988 as cited in Pallant, 2005). In a similar way, there was no significant 
difference in mean attitude scores between Time $2(\mathrm{M}=14.61, \mathrm{SD}=3.96)$ and Time $3(\mathrm{M}=14.98, \mathrm{SD}=4.59), \mathrm{t}(45)=-.91, \mathrm{p}=.261, \eta^{2}=.03$ indicating small effect size (Cohen, 1988 as cited in Pallant, 2005).

Table 4.25: Paired T-test Results for Control Group

\begin{tabular}{ccccccccccc}
\hline & & \multicolumn{9}{c}{ Paired Differences } \\
\cline { 3 - 7 } Pair & Time & MD & SD & SE & $\begin{array}{c}\text { Lower } \\
\text { Limit }\end{array}$ & $\begin{array}{c}\text { Upper } \\
\text { Limit }\end{array}$ & T & df & $\eta^{2}$ \\
\hline 1 & $1-2$ & -0.59 & 2.69 & 0.40 & -1.39 & 0.21 & -1.48 & 45 & .05 \\
2 & $1-3$ & -0.96 & 2.97 & 0.44 & -1.84 & -0.08 & -2.19 & 45 & .10 \\
3 & $2-3$ & -0.37 & 2.74 & 0.40 & -1.18 & 0.45 & -.91 & 45 & .03 \\
\hline
\end{tabular}

The estimated marginal means of attitude graph illustrated that the mean attitude scores of the students in control group slightly increased over time. However, these increases were not statistically significant. Those of the students in experimental group fluctuated over time. Their mean attitude scores were highest after the visit. Their mean attitudes were still significantly higher than those before the visit even though those decreased one week later. This result suggested that METU SC is effective in changing students' attitudes towards future participation in science positively (Figure 4.6). 
Estimated Marginal Means of Attitude

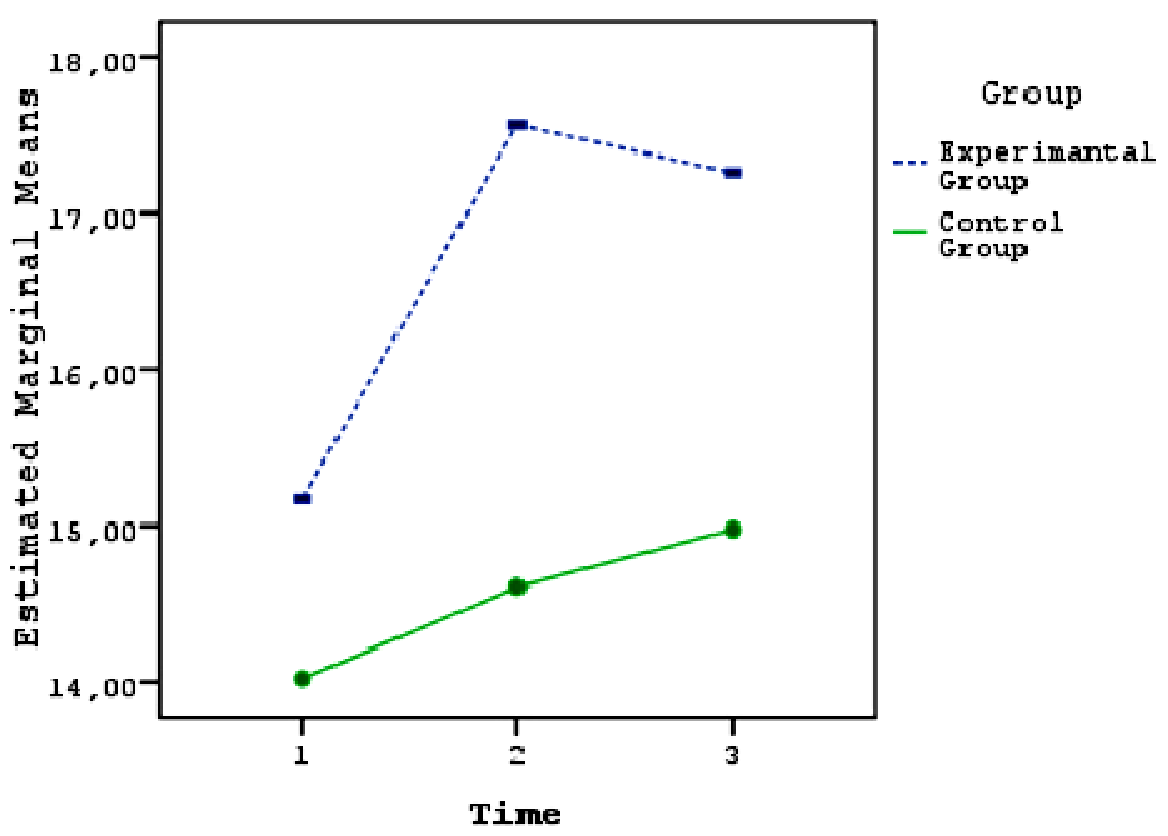

Figure 4.6: The Comparison of Estimated Marginal Means of Attitude towards Future Participation in Science across the Three Time Periods for Experimental and Control Group

\subsubsection{Sub- research question 6}

Sub- Research Hypothesis 6: Attitudes towards importance of science

$\mathrm{H}_{61}$ : There is no change in mean scores of $6^{\text {th }}$ grade students' attitudes towards importance of science across the three time periods.

$\mathrm{H}_{62}$ : There are no differences in mean scores of $6^{\text {th }}$ grade students' attitudes towards importance of science between the experimental and control group across the three time periods. 
$\mathrm{H}_{63}$ : The change is not the same in mean scores of $6^{\text {th }}$ grade students' attitudes towards importance of science across the three time periods for the different groups (experimental and control group).

The descriptive statistics for mean attitude scores of both groups across the three time periods can be seen in Table 4.26.

Table 4.26: Descriptive Statistics for Attitude Scores of Both Groups

\begin{tabular}{ccccc}
\hline & Group & M & SD & N \\
\hline Time 1 & Experimental & 16.57 & 2.93 & 46 \\
& Control & 16.65 & 3.75 & 46 \\
& Total & 16.61 & 3.35 & 92 \\
Time 2 & Experimental & 18.09 & 2.87 & 46 \\
& Control & 16.30 & 3.53 & 46 \\
& Total & 17.20 & 3.33 & 92 \\
Time 3 & Experimental & 18.54 & 2.04 & 46 \\
& Control & 16.30 & 3.63 & 46 \\
& Total & 17.42 & 3.14 & 92 \\
\hline
\end{tabular}

Box's M statistics had been violated (Box's $M=20.17, p=.003<.050$ ), therefore Pillai's trace values were used instead of Wilks' Lambdas. The multivariate results indicated a significant main effect for time [Pillai's trace $=.09, \mathrm{~F}(2,89)=4.35$, $\mathrm{p}=.016, \eta^{2}=.09$ indicating moderate effect size (Cohen, 1988 as cited in Pallant, 2005) (see Table 4.27)]. Bonferroni pairwise comparisons result for time revealed that there was no significant increase in mean attitude scores from Time 1 $(\mathrm{M}=16.61, \mathrm{SE}=.35)$ to Time $2(\mathrm{M}=17.20, \mathrm{SE}=.34)$. Similarly, there was no significant difference in mean attitude scores between Time $2(17.20, \mathrm{SE}=.34)$ and Time $3(\mathrm{M}=17.42, \mathrm{SE}=.31)$. Nevertheless, there was a significant difference in mean attitude scores between Time $1(\mathrm{M}=16.61, \mathrm{SE}=.35)$ and Time $3(\mathrm{M}=17.42$, $\mathrm{SE}=.31)$.

Furthermore, a significant group-by-time interaction effect was obtained [Pillai's trace $=.16, \mathrm{~F}(2,89)=8.66, \mathrm{p}=.000, \eta^{2}=.16$ indicating large effect size $($ Cohen, 
1988 as cited in Pallant, 2005) (see Table 4.27)]. This result revealed that the change in mean attitude scores towards importance of science across the three time periods was not the same for experimental and control groups.

A significant main effect for group was obtained, $F(1,90)=5.63, p=.020<.050$, $\eta^{2}=.06$ indicating a moderate effect (Cohen, 1988 as cited in Pallant, 2005) (see Table 4.27). Bonferroni pairwise comparisons result revealed that there was a significant difference in mean attitude scores towards importance of science between the experimental $(\mathrm{M}=17.73, \mathrm{SE}=.39)$ and the control group $(\mathrm{M}=16.42$, $\mathrm{SE}=.39)$.

Table 4.27: Multivariate Test Result

\begin{tabular}{clccc}
\hline Effect & $\begin{array}{c}\text { Pillai's } \\
\text { Trace }\end{array}$ & $\mathrm{F}^{\mathrm{a}}$ & $\eta^{2}$ & Observed Power \\
\hline Time & .09 & $4.35^{*}$ & .09 & .74 \\
Time ${ }^{*}$ group & .16 & $8.66^{* *}$ & .16 & .96 \\
\hline Note. ${ }^{\mathrm{a}}$ Multivariate $\mathrm{df}=2,89 .{ }^{*} \mathrm{p}<.05,{ }^{* *} \mathrm{p}<.001$. & &
\end{tabular}

In the lights of information given above, while $\mathrm{H}_{61}$ and $\mathrm{H}_{62}$ were rejected, $\mathrm{H}_{63}$ was failed to reject. Moreover, in order to determine the change in mean attitude scores of students in both groups over time, paired t-tests were conducted.

\section{Paired T-test for Experimental Group}

There was a significant increase in mean attitude scores from Time $1(\mathrm{M}=16.57$, $\mathrm{SD}=2.93)$ to Time $2(\mathrm{M}=18.09, \mathrm{SD}=2.87), \mathrm{t}(45)=-3.32, \mathrm{p}=.002, \eta^{2}=.20$ indicating very large effect (Cohen, 1988 as cited in Pallant, 2005). Similarly, there was a significant difference in mean attitude scores between the Time $1(\mathrm{M}=16.57$, $\mathrm{SD}=2.93)$ and Time $3(\mathrm{M}=18.54, \mathrm{SD}=2.04), \mathrm{t}(45)=-4.99, \mathrm{p}=.000, \eta^{2}=.36$ indicating very large effect (Cohen, 1988 as cited in Pallant, 2005). However, there 
was no significant difference in mean attitude scores between Time $2(\mathrm{M}=18.09$, $\mathrm{SD}=2.87)$ and Time $3(\mathrm{M}=18.54, \mathrm{SD}=2.04), \mathrm{t}(45)=-.27, \mathrm{p}=.214, \eta^{2}=.002$ indicating very small effect (Cohen, 1988 as cited in Pallant).

Table 4.28: Paired T-test Results for Experimental Group

\begin{tabular}{|c|c|c|c|c|c|c|c|c|c|}
\hline \multirow[b]{3}{*}{ Pair } & \multirow[b]{3}{*}{ Time } & \multicolumn{5}{|c|}{ Paired Differences } & \multirow[b]{3}{*}{$\mathrm{T}$} & \multirow[b]{3}{*}{ df } & \multirow[b]{3}{*}{$\eta^{2}$} \\
\hline & & \multirow[b]{2}{*}{ MD } & \multirow[b]{2}{*}{ SD } & \multirow[b]{2}{*}{ SE } & \multicolumn{2}{|c|}{$95 \% \mathrm{CI}$} & & & \\
\hline & & & & & $\begin{array}{l}\text { Lower } \\
\text { Limit }\end{array}$ & $\begin{array}{l}\text { Upper } \\
\text { Limit }\end{array}$ & & & \\
\hline 1 & $1-2$ & -1.52 & 3.11 & 0.46 & -2.45 & -0.60 & $-3.32 *$ & 45 & .20 \\
\hline 2 & $1-3$ & -1.98 & 2.69 & 0.40 & -2.78 & -1.18 & $-4.99 * *$ & 45 & .36 \\
\hline 3 & $2-3$ & -0.46 & 2.46 & 0.36 & -1.19 & 0.27 & -1.26 & 45 & .002 \\
\hline
\end{tabular}

\section{Paired T-test for Control Group}

There were no significant differences in mean attitude scores over time. There was no significant difference in mean attitude scores between Time $1(\mathrm{M}=16.65$, $\mathrm{SD}=3.75)$ and Time $2(\mathrm{M}=16.30, \mathrm{SD}=3.53), \mathrm{t}(45)=.57, \mathrm{p}=.568, \eta^{2}=.01$ indicating small effect (Cohen, 1988 as cited in Pallant, 2005). Similarly, there was no significant difference in mean attitude scores between Time $1(\mathrm{M}=16.65$, $\mathrm{SD}=3.75)$ and Time $3(\mathrm{M}=16.30, \mathrm{SD}=3.63), \mathrm{t}(45)=.88, \mathrm{p}=.381, \eta^{2}=.02$ indicating small effect (Cohen, 1988 as cited in Pallant, 2005). And also, there was no significant difference in mean attitude scores between Time $2(\mathrm{M}=16.30$, $\mathrm{SD}=3.53)$ and Time $3(\mathrm{M}=16.30, \mathrm{SD}=3.63), \mathrm{t}(45)=.00, \mathrm{p}=1.000$. 
Table 4.29: Paired T-test Results for Control Group

\begin{tabular}{|c|c|c|c|c|c|c|c|c|c|}
\hline \multirow[b]{3}{*}{ Pair } & \multirow[b]{3}{*}{ Time } & \multicolumn{5}{|c|}{ Paired Differences } & \multirow[b]{3}{*}{$\mathrm{t}$} & \multirow[b]{3}{*}{ df } & \multirow[b]{3}{*}{$\eta^{2}$} \\
\hline & & \multirow[b]{2}{*}{ MD } & \multirow[b]{2}{*}{$\mathrm{SD}$} & \multirow[b]{2}{*}{ SE } & \multicolumn{2}{|c|}{$95 \% \mathrm{CI}$} & & & \\
\hline & & & & & $\begin{array}{l}\text { Lower } \\
\text { Limit }\end{array}$ & $\begin{array}{l}\text { Upper } \\
\text { Limit }\end{array}$ & & & \\
\hline 1 & $1-2$ & 0.35 & 4.11 & 0.61 & -0.87 & 1.57 & 0.57 & 45 & .01 \\
\hline 2 & $1-3$ & 0.35 & 2.67 & 0.39 & -0.44 & 1.14 & 0.88 & 45 & .02 \\
\hline 3 & $2-3$ & 0.00 & 3.00 & 0.44 & -0.89 & 0.89 & 0.00 & 45 & .00 \\
\hline
\end{tabular}

The estimated marginal means of attitude graph illustrated that the mean attitude scores of the students in control group decreased at second measurement, and stayed same. Those of the students in experimental group, whereas, increased across the three time periods. This result suggested that METU SC is effective in changing students' attitudes towards importance of science positively (Figure 4.7). 
Estimated Marginal Means of Attitude

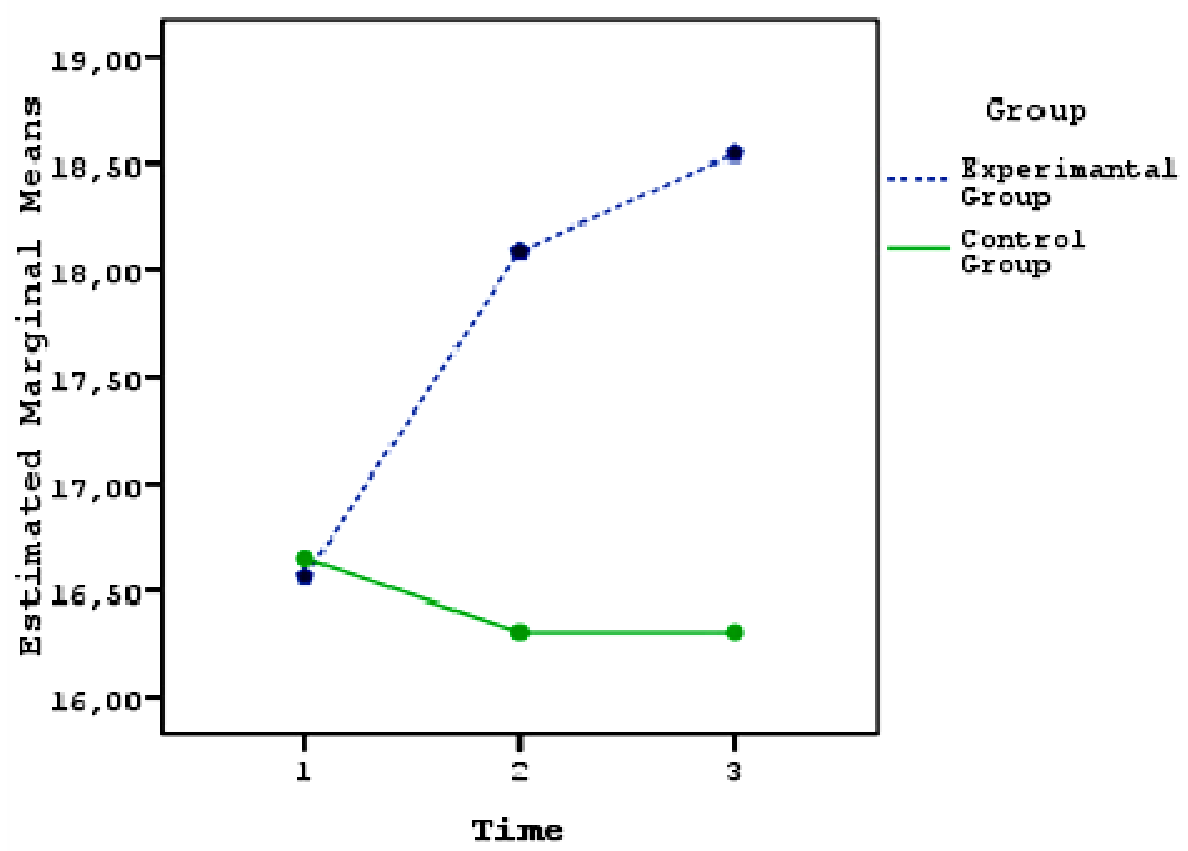

Figure 4.7: The Comparison of Estimated Marginal Means of Attitude towards Importance of Science across the Three Time Periods for Experimental and Control Group

\subsection{The Results of Design 2}

The purpose of the design 2 was to determine the impact of Middle East Technical University's Science Centre on students' overall attitudes towards science with regard to their gender, grade levels, and science achievement scores. 


\subsubsection{Research Question 1}

Research Hypothesis: Overall attitudes towards science with respect to gender

$\mathrm{H}_{11}$ : There is no change in students' mean attitude scores towards science over the three time periods.

$\mathrm{H}_{12}$ : There is no impact of gender type on mean attitude scores towards science.

$\mathrm{H}_{13}$ : The change is not the same in mean attitude scores towards science over the three time periods for boys and girls.

The descriptive statistics for demographic variables can be seen in Table 4.30.

Table 4.30: Descriptive Statistics of Demographic Variables

\begin{tabular}{cccc}
\hline Measure & & $\mathrm{N}$ & $\%$ \\
Gender & & & \\
& Male & 84 & 52.8 \\
Age & Female & 75 & 47.2 \\
& 12 & 56 & 35.2 \\
& 13 & 53 & 33.3 \\
Grade & 14 & 50 & 31.4 \\
& & & \\
& $6^{\text {th }}$ & 52 & 32.7 \\
& $7^{\text {th }}$ & 55 & 34.6 \\
& $8^{\text {th }}$ & 52 & 32.7 \\
& & 49 & 30.4 \\
Total & (average) & 54 & 34.0 \\
& 4 (good) & 56 & 35.2 \\
& 5 (excellent) & 159 & 100 \\
\hline
\end{tabular}


The descriptive statistics for attitude scores over time were presented in Table 4.31 .

Table 4.31: Descriptive Statistics of Attitude Scores for Males and Females

\begin{tabular}{ccccc}
\hline & Gender & $\mathrm{M}$ & $\mathrm{SD}$ & $\mathrm{N}$ \\
\hline Time 1 & Male & 127.48 & 22.03 & 84 \\
& Female & 129.97 & 19.81 & 75 \\
& Total & 128.65 & 20.99 & 159 \\
Time 2 & Male & 138.08 & 16.67 & 84 \\
& Female & 142.65 & 15.32 & 75 \\
& Total & 140.24 & 16.16 & 159 \\
Time 3 & Male & 137.14 & 20.24 & 84 \\
& Female & 138.59 & 16.31 & 75 \\
& Total & 137.82 & 18.45 & 159 \\
\hline
\end{tabular}

Mauchly's test indicated that the assumption of sphericity had not been violated $\left[\chi^{2}(2)=2.68 p=.261>.050\right]$; therefore sphericity assumed $\mathrm{F}$ test results for time and gender were used. A mixed-model analysis of variance revealed that the main effect for time was significant, $F(2,314)=80.57, \mathrm{p}=.000<.050, \eta^{2}=.34$ indicating a very large effect (Cohen, 1988 as cited in Pallant, 2005) (see Table 4.32). Bonferroni pairwise comparisons result revealed that there was a significant increase in mean attitude scores from Time $1(\mathrm{M}=128.73, \mathrm{SE}=1.67)$ to Time 2 $(\mathrm{M}=140.37, \mathrm{SE}=1.27)$. Similarly, there was a significant difference between Time $1(\mathrm{M}=128.73, \mathrm{SE}=1.67)$ and Time $3(\mathrm{M}=137.86, \mathrm{SE}=1.47)$. However, there was a significant decrease in mean attitude scores from Time $2(\mathrm{M}=140.37, \mathrm{SE}=1.27)$ to Time $3(\mathrm{M}=137.86, \mathrm{SE}=1.47)$.

A significant main effect for gender was not obtained, $F(1,157)=1.07$, $\mathrm{p}=.302>.050, \eta^{2}$ was equal to .01 . Not surprisingly, it indicated small effect (Cohen, 1988 as cited in Pallant, 2005) (see Table 4.32). Bonferroni pairwise comparisons result revealed that there was no significant difference in mean attitude scores between the boys $(\mathrm{M}=134.23, \mathrm{SE}=1.88)$ and girls $(\mathrm{M}=137.07$, $\mathrm{SE}=1.99)$. This result showed that gender type did not significantly influence students' mean attitude scores towards science over time. 
Furthermore, there was no significant time* group interaction effect, $\mathrm{F}(2,314)=1.36, \mathrm{p}=.259>.050, \eta^{2}=.01$ indicating small effect (Cohen, 1988 as cited in Pallant, 2005) (see Table 4.32). This result suggested that the overall change in mean attitude scores over time is statistically same for boys and girls.

Table 4.32: Analysis of Variance Results for Effects

\begin{tabular}{cccccc}
\hline Source & SS & df & MS & F & $\eta^{2}$ \\
\hline Between subjects & & & & & \\
Group & 318.90 & 1 & 318.90 & 1.07 & .01 \\
Error & $46,752.68$ & 157 & 297.79 & & \\
Within Subjects & & & & & \\
Time & $11,906.88$ & 2.00 & $5,953.44$ & $80.57 * *$ & .34 \\
Time* Group & 200.48 & 2.00 & 100.24 & 1.36 & .01 \\
Error & $23,200.73$ & 314.00 & 73.89 & & \\
\hline Note. ${ }^{*} \mathrm{p}<.05,{ }^{* *} \mathrm{p}<.001$. & & & & &
\end{tabular}

In the lights of information given above, all proposed hypotheses were rejected. Furthermore, in order to obtain detailed information about differences in mean attitude scores over time, paired t-tests were conducted for time, boys and girls.

\section{Paired t-test for Time}

There was a significant increase in mean attitude scores from Time $1(\mathrm{M}=128.65$, $\mathrm{SD}=20.99)$ to Time $2(\mathrm{M}=140.24, \mathrm{SD}=16.16), \mathrm{t}(158)=-11.33, \mathrm{p}=.000, \eta^{2}=.45$ indicating very large effect (Cohen, 1988 as cited in Pallant, 2005). Similarly, there was a significant difference in mean attitude scores between Time $1(\mathrm{M}=128.65$, $\mathrm{SD}=20.99)$ and Time $3(\mathrm{M}=137.82, \mathrm{SD}=18.45), \mathrm{t}(158)=-9.69, \mathrm{p}=.000, \eta^{2}=.37$ indicating very large effect (Cohen, 1988 as cited in Pallant, 2005). However, there was a significant decrease in mean attitude scores from Time $2(\mathrm{M}=140.24$, $\mathrm{SD}=16.16)$ to Time $3(\mathrm{M}=137.82, \mathrm{SD}=18.45), \mathrm{t}(158)=2.62, \mathrm{p}=.010, \eta^{2}=.02$ indicating small effect size (Cohen, 1988 as cited in Pallant, 2005). 
Table 4.33: Paired T-test Results for Time

\begin{tabular}{|c|c|c|c|c|c|c|c|c|c|}
\hline \multirow[b]{3}{*}{ Pair } & \multirow[b]{3}{*}{ Time } & \multicolumn{5}{|c|}{ Paired Differences } & \multirow[b]{3}{*}{$\mathrm{T}$} & \multirow[b]{3}{*}{$\mathrm{df}$} & \multirow[b]{3}{*}{$\eta^{2}$} \\
\hline & & \multirow[b]{2}{*}{ MD } & \multirow[b]{2}{*}{$\mathrm{SD}$} & \multirow[b]{2}{*}{$\mathrm{SE}$} & \multicolumn{2}{|c|}{$95 \% \mathrm{CI}$} & & & \\
\hline & & & & & $\begin{array}{l}\text { Lower } \\
\text { Limit }\end{array}$ & $\begin{array}{l}\text { Upper } \\
\text { Limit }\end{array}$ & & & \\
\hline 1 & $1-2$ & -11.58 & 12.90 & 1.02 & -13.61 & -9.56 & $-11.33 * *$ & 158 & .45 \\
\hline 2 & $1-3$ & -9.17 & 11.94 & 0.95 & -11.04 & -7.30 & $-9.69 * *$ & 158 & .37 \\
\hline 3 & $2-3$ & 2.42 & 11.64 & 0.92 & 0.59 & 4.24 & $2.62 *$ & 158 & .02 \\
\hline
\end{tabular}

\section{Paired t-test for Boys}

There was a significant increase in mean attitude scores from Time $1(M=127.48$, $\mathrm{SD}=22.03)$ to Time $2(\mathrm{M}=138.08, \mathrm{SD}=16.67), \mathrm{t}(83)=-7.37, \mathrm{p}=.000, \eta^{2}=.38$ indicating very large effect (Cohen, 1988 as cited in Pallant, 2005). Moreover, there was a significant difference in mean attitude scores between Time 1 $(\mathrm{M}=127.48, \mathrm{SD}=22.03)$ and Time $3(\mathrm{M}=137.14, \mathrm{SD}=20.24), \mathrm{t}(83)=-7.59$, $\mathrm{p}=.000, \eta^{2}=.40$ indicating very large effect (Cohen, 1988 as cited in Pallant, 2005). However, there was no significant difference in mean attitude scores between Time $2(\mathrm{M}=138.08, \mathrm{SD}=16.67)$ and Time $3(\mathrm{M}=137.14, \mathrm{SD}=20.24)$, $\mathrm{t}(83)=.71, \mathrm{p}=.478, \eta^{2}=.01$ indicating small effect size (Cohen, 1988 as cited in Pallant, 2005).

Table 4.34: Paired T-test Results for Boys

\begin{tabular}{|c|c|c|c|c|c|c|c|c|c|}
\hline \multirow[b]{3}{*}{ Pair } & \multirow[b]{3}{*}{ Time } & \multicolumn{5}{|c|}{ Paired Differences } & \multirow[b]{3}{*}{$\mathrm{T}$} & \multirow[b]{3}{*}{$\mathrm{df}$} & \multirow[b]{3}{*}{$\eta^{2}$} \\
\hline & & \multirow[b]{2}{*}{ MD } & \multirow[b]{2}{*}{$\mathrm{SD}$} & \multirow[b]{2}{*}{$\mathrm{SE}$} & \multicolumn{2}{|c|}{$95 \% \mathrm{CI}$} & & & \\
\hline & & & & & $\begin{array}{l}\text { Lower } \\
\text { Limit }\end{array}$ & $\begin{array}{l}\text { Upper } \\
\text { Limit }\end{array}$ & & & \\
\hline 1 & $1-2$ & -10.61 & 13.18 & 1.44 & -13.47 & -7.75 & $-7.37 * *$ & 83 & .38 \\
\hline 2 & $1-3$ & -9.67 & 11.67 & 1.27 & -12.20 & -7.13 & $-7.59 * *$ & 83 & .40 \\
\hline 3 & $2-3$ & 0.94 & 12.10 & 1.32 & -1.69 & 3.57 & .71 & 83 & .01 \\
\hline
\end{tabular}




\section{Paired t-test for Girls}

There was a significant increase in mean attitude scores from Time $1(\mathrm{M}=129.97$, $\mathrm{SD}=19.81)$ to Time $2(\mathrm{M}=142.65, \mathrm{SD}=15.32), \mathrm{t}(74)=-8.74, \mathrm{p}=.000, \eta^{2}=.51$ indicating very large effect (Cohen, 1988 as cited in Pallant, 2005). Moreover, there was a significant difference in mean attitude scores between Time 1 $(\mathrm{M}=129.97, \mathrm{SD}=19.81)$ and Time $3(\mathrm{M}=138.59, \mathrm{SD}=16.31), \mathrm{t}(74)=-6.07$, $\mathrm{p}=.000, \eta^{2}=.33$ indicating very large effect (Cohen, 1988 as cited in Pallant, 2005). However, there was a significant decrease in mean attitude scores from Time $2(\mathrm{M}=142.65, \mathrm{SD}=15.32)$ to Time $3(\mathrm{M}=138.59, \mathrm{SD}=16.31), \mathrm{t}(74)=3.22$, $\mathrm{p}=.002, \eta^{2}=.12$ indicating moderate effect size (Cohen, 1988 as cited in Pallant, 2005).

Table 4.35: Paired T-test Results for Girls

\begin{tabular}{|c|c|c|c|c|c|c|c|c|c|}
\hline \multirow[b]{3}{*}{ Pair } & \multirow[b]{3}{*}{ Time } & \multicolumn{5}{|c|}{ Paired Differences } & \multirow[b]{3}{*}{$\mathrm{t}$} & \multirow[b]{3}{*}{ df } & \multirow[b]{3}{*}{$\eta^{2}$} \\
\hline & & \multirow[b]{2}{*}{ MD } & \multirow[b]{2}{*}{ SD } & \multirow[b]{2}{*}{$\mathrm{SE}$} & \multicolumn{2}{|c|}{$95 \% \mathrm{CI}$} & & & \\
\hline & & & & & $\begin{array}{l}\text { Lower } \\
\text { Limit }\end{array}$ & $\begin{array}{l}\text { Upper } \\
\text { Limit }\end{array}$ & & & \\
\hline 1 & $1-2$ & -12.68 & 12.57 & 1.45 & -15.57 & -9.79 & $-8.74 * *$ & 74 & .51 \\
\hline 2 & $1-3$ & -8.61 & 12.28 & 1.42 & -11.44 & -5.79 & $-6.07 * *$ & 74 & .33 \\
\hline 3 & $2-3$ & 4.07 & 10.95 & 1.26 & 1.55 & 6.59 & $3.22 *$ & 74 & .12 \\
\hline
\end{tabular}

The estimated marginal means of attitude graph illustrated that students' mean attitude scores significantly increased immediately after the visit. Furthermore, the students' mean attitude scores one week later were still significantly higher than those were before the visit even though those were significantly lower than immediately after the visit (Figure 4.8). This result suggested that METU SC is effective in changing students' attitudes towards science in positive way. Furthermore, the overall changes in mean attitude scores over time were statistically same for boys and girls. This result suggested that METU SC 
influences both boys and girls equally in changing their attitudes towards science. Besides, regardless of the research question, while boys' mean attitude scores almost never changed in one week after the visit, girls' mean attitude scores decreased significantly (Figure 4.9).

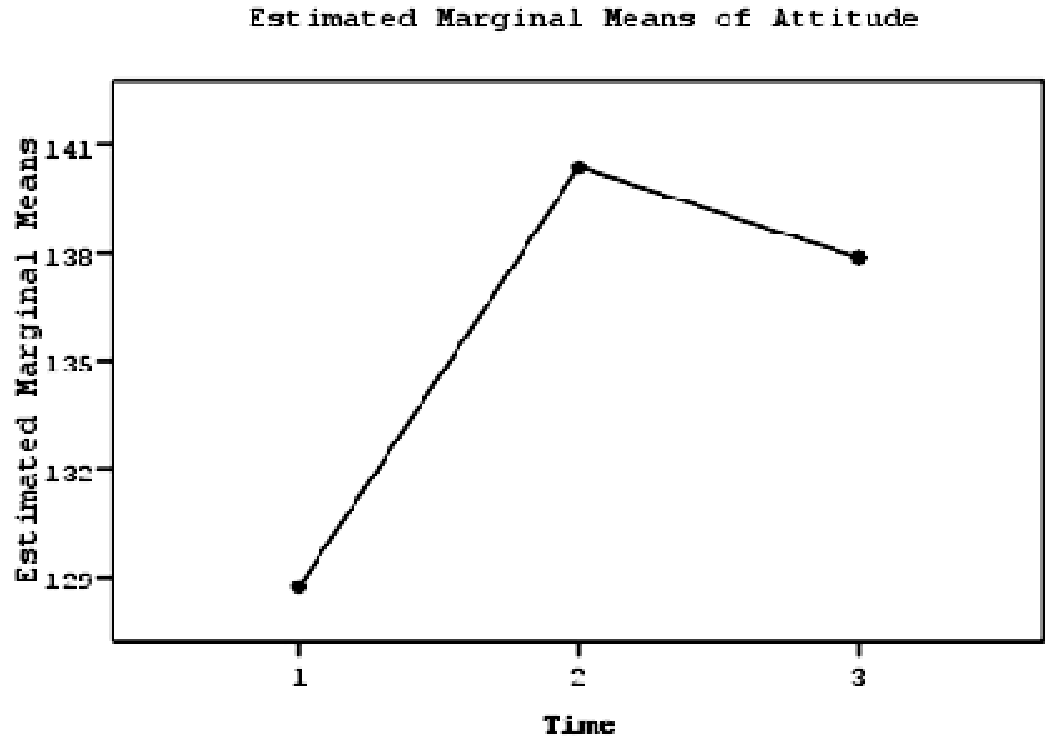

Figure 4.8: Estimated Marginal Means of Attitude over the Three Time Periods 


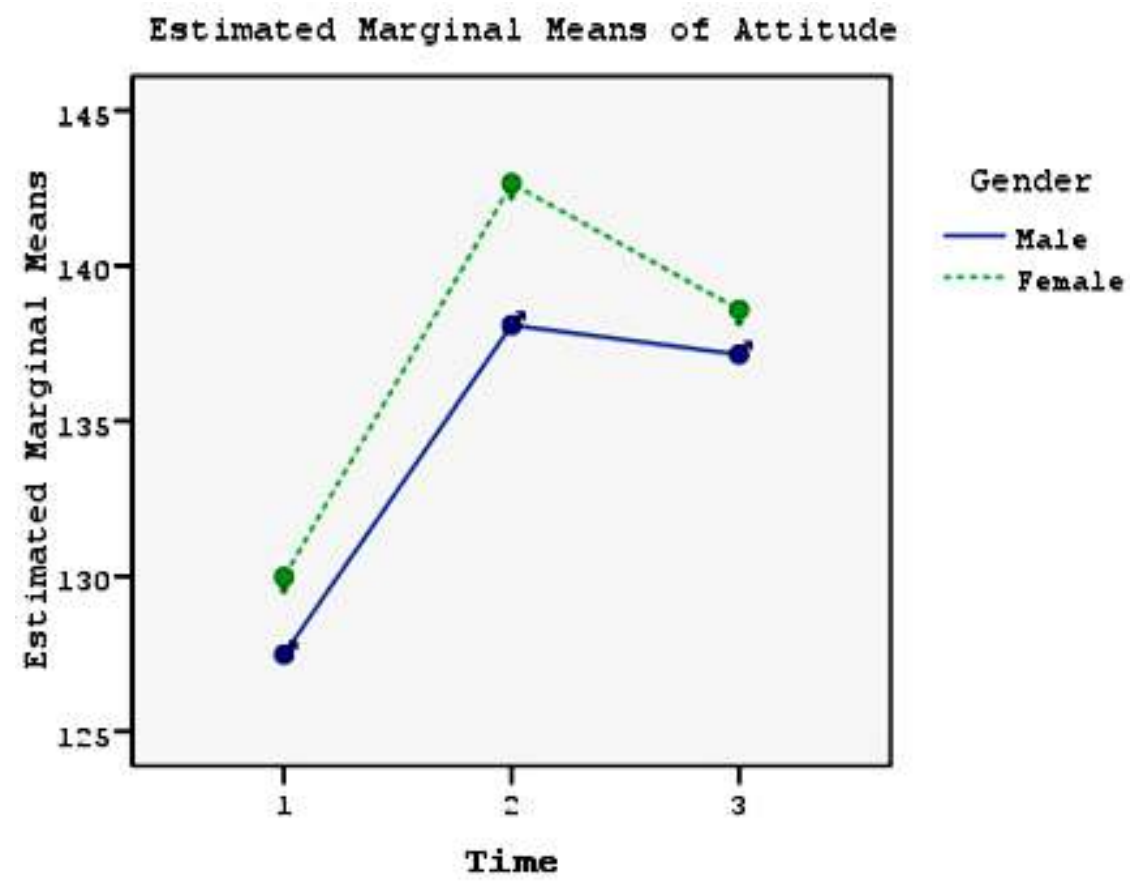

Figure 4.9: Estimated Marginal Means of Attitude across the Three Time Periods for Males and Females

\subsubsection{Research Question 2}

Research Hypothesis: Overall attitudes towards science with respect to grade levels

$\mathrm{H}_{21}$ : There is no change in students' mean attitude scores towards science across the three time periods.

$\mathrm{H}_{22}$ : There is no impact of grade levels on mean attitude scores towards science across the three time periods. 
$\mathrm{H}_{23}$ : The change is not the same in mean attitude scores towards science across the three time periods for different graders.

The sample consisted of $52(32.7 \%) 6^{\text {th }}$ graders, $55(34.6 \%) 7^{\text {th }}$ graders, and 52 $(32.7 \%) 8^{\text {th }}$ graders. The descriptive statistics were presented in Table 4.34.

Table 4.36: Descriptive Statistics of Attitude Scores for Grade Levels

\begin{tabular}{ccccc}
\hline & Grades & M & SD & N \\
\hline Time 1 & 6th & 134.35 & 19.10 & 52 \\
& 7th & 129.36 & 21.29 & 55 \\
& 8th & 122.21 & 21.07 & 52 \\
Time 2 & Total & 128.65 & 20.99 & 159 \\
& 6th & 144.35 & 14.30 & 52 \\
& 7th & 141.44 & 17.53 & 55 \\
Time 3 & 8th & 134.87 & 15.20 & 52 \\
& Total & 140.24 & 16.16 & 159 \\
& 6th & 141.73 & 17.77 & 52 \\
& 7th & 138.27 & 20.23 & 55 \\
& 8th & 133.44 & 16.43 & 52 \\
& Total & 137.82 & 18.45 & 159 \\
\hline
\end{tabular}

Mauchly's test indicated that the assumption of sphericity had not been violated $\left[\chi^{2}(2)=2.52 \mathrm{p}=.284>.050\right]$; therefore sphericity assumed $\mathrm{F}$ test results for time and grade levels were used. A mixed-model analysis of variance revealed that the main effect for time was significant, $F(2,312)=79.83, p=.000<.050, \eta^{2}=.34$ indicating a very large effect (Cohen, 1988 as cited in Pallant, 2005) (see Table 4.35). Hence, there was a difference in mean attitude scores towards science over time.

A significant main effect for grade levels was obtained, $F(2,156)=4.63$, $\mathrm{p}=.011<.050, \eta^{2}$ was equal to .06. It indicated a moderate effect (Cohen, 1988 as cited in Pallant, 2005) (see Table 4.35). This result showed that grade levels did significantly influence mean attitude scores towards science. Bonferroni pairwise 
comparisons result revealed that there was a significant difference in mean attitude scores between the $6^{\text {th }}$ graders $(M=140.14, S E=2.34)$ and $8^{\text {th }}$ graders $(M=130.17$, $\mathrm{SE}=2.34)$. However, there was no significant difference in mean attitude scores between $6^{\text {th }}(M=140.14, S E=2.34)$ graders and $7^{\text {th }}(M=136.36, S E=2.28)$ graders. Similarly, there was no significant difference in mean attitude scores between $7^{\text {th }}$ $(\mathrm{M}=136.36, \mathrm{SE}=2.28)$ graders and $8^{\text {th }}$ graders $(\mathrm{M}=130.17, \mathrm{SE}=2.34)$.

However, there was no significant time*grade interaction effect, $F(4,312)=.76$, $\mathrm{p}=.552>.050, \eta^{2}=.01$ indicating a small effect (Cohen, 1988 as cited in Pallant, 2005) (see Table 4.35). This indicated that the overall change in mean attitude scores of students in different grade levels over time is statistically same.

Table 4.37: Analysis of Variance Results for Effects

\begin{tabular}{cccccc}
\hline Source & SS & df & MS & F & $\eta^{2}$ \\
\hline Between subjects & & & & & \\
Grade & 2635.21 & 2 & 1317.61 & $4.63^{*}$ & .06 \\
Error & 44436.38 & 156 & 284.85 & & \\
Within Subjects & & & & & \\
Time & 11860.18 & 2 & 5960.09 & $79.83^{* *}$ & .34 \\
Time* Grade & 225.84 & 4 & 56.46 & .76 & .01 \\
Error & 23175.36 & 312 & 74.28 & & \\
\hline Note. ${ }^{*} \mathrm{p}<.05,{ }^{* *} \mathrm{p}<.001$. & & & & &
\end{tabular}

In the lights of information given above, all proposed hypotheses were rejected. In addition, in order to determine the change in mean attitude scores across the three time periods with respect to grade levels, paired t-tests were conducted.

\section{Paired t-test for $6^{\text {th }}$ Graders}

There was a significant increase in mean attitude scores from Time $1(\mathrm{M}=134.35$, $\mathrm{SD}=19.10)$ to Time $2(\mathrm{M}=144.35, \mathrm{SD}=14.30), \mathrm{t}(51)=-5.65, \mathrm{p}=.000, \eta^{2}=.39$ indicating very large effect (Cohen, 1988 as cited in Pallant, 2005). Besides, there 
was a significant difference in mean attitude scores between Time $1(\mathrm{M}=134.35$, $\mathrm{SD}=19.10)$ and Time $3(\mathrm{M}=141.73, \mathrm{SD}=17.77), \mathrm{t}(51)=-3.87, \mathrm{p}=.000, \eta^{2}=.23$ indicating very large effect (Cohen, 1988 as cited in Pallant, 2005). However, there was no significant difference in mean attitude scores between Time $2(\mathrm{M}=144.35$, $\mathrm{SD}=14.30)$ and Time $3(\mathrm{M}=141.73, \mathrm{SD}=17.77), \mathrm{t}(51)=1.44, \mathrm{p}=.157, \eta^{2}=.04$ indicating small effect size (Cohen, 1988 as cited in Pallant, 2005).

Table 4.38: Paired T-test Results for $6^{\text {th }}$ Graders

\begin{tabular}{|c|c|c|c|c|c|c|c|c|c|}
\hline \multirow[b]{3}{*}{ Pair } & \multirow[b]{3}{*}{ Time } & \multicolumn{5}{|c|}{ Paired Differences } & \multirow[b]{3}{*}{$\mathrm{T}$} & \multirow[b]{3}{*}{$\mathrm{df}$} & \multirow[b]{3}{*}{$\eta^{2}$} \\
\hline & & \multirow[b]{2}{*}{ MD } & \multirow[b]{2}{*}{ SD } & \multirow[b]{2}{*}{$\mathrm{SE}$} & \multicolumn{2}{|c|}{$95 \%$ CI } & & & \\
\hline & & & & & $\begin{array}{c}\text { Lower } \\
\text { Limit }\end{array}$ & $\begin{array}{l}\text { Upper } \\
\text { Limit }\end{array}$ & & & \\
\hline 1 & $1-2$ & -10.00 & 12.77 & 1.77 & -13.56 & -6.44 & $-5.65 * *$ & 51 & .39 \\
\hline 2 & $1-3$ & -7.38 & 13.78 & 1.91 & -11.22 & -3.55 & $-3.87 * *$ & 51 & .23 \\
\hline 3 & $2-3$ & 2.62 & 13.13 & 1.82 & -1.04 & 6.27 & 1.44 & 51 & .04 \\
\hline
\end{tabular}

\section{Paired t-test for $7^{\text {th }}$ Graders}

There was a significant increase in mean attitude scores from Time $1(\mathrm{M}=129.36$, $\mathrm{SD}=21.28)$ to Time $2(\mathrm{M}=141.44, \mathrm{SD}=17.53), \mathrm{t}(54)=-6.60, \mathrm{p}=.000, \eta^{2}=.45$ indicating very large effect (Cohen, 1988 as cited in Pallant, 2005). Furthermore, there was a significant difference in mean attitude scores between Time 1 $(\mathrm{M}=129.36, \mathrm{SD}=21.28)$ and Time $3(\mathrm{M}=138.27, \mathrm{SD}=20.23), \mathrm{t}(54)=-6.59$, $\mathrm{p}=.000, \eta^{2}=.45$ indicating very large effect (Cohen, 1988 as cited in Pallant, 2005). However, there was no significant difference in mean attitude scores between Time $2(\mathrm{M}=141.44, \mathrm{SD}=17.53)$ and Time $3(\mathrm{M}=138.27, \mathrm{SD}=20.23)$, $\mathrm{t}(54)=1.78, \mathrm{p}=.080, \eta^{2}=.06$ indicating moderate effect size (Cohen, 1988 as cited in Pallant, 2005). 
Table 4.39: Paired T-test Results for $7^{\text {th }}$ Graders

\begin{tabular}{|c|c|c|c|c|c|c|c|c|c|}
\hline \multirow[b]{3}{*}{ Pair } & \multirow[b]{3}{*}{ Time } & \multicolumn{5}{|c|}{ Paired Differences } & \multirow[b]{3}{*}{$\mathrm{t}$} & \multirow[b]{3}{*}{ df } & \multirow[b]{3}{*}{$\eta^{2}$} \\
\hline & & \multirow[b]{2}{*}{ MD } & \multirow[b]{2}{*}{$\mathrm{SD}$} & \multirow[b]{2}{*}{$\mathrm{SE}$} & \multicolumn{2}{|c|}{$95 \% \mathrm{CI}$} & & & \\
\hline & & & & & $\begin{array}{l}\text { Lower } \\
\text { Limit }\end{array}$ & $\begin{array}{l}\text { Upper } \\
\text { Limit }\end{array}$ & & & \\
\hline 1 & $1-2$ & -12.07 & 13.57 & 1.83 & -15.74 & -8.41 & $-6.60 * *$ & 54 & .45 \\
\hline 2 & $1-3$ & -8.91 & 10.02 & 1.35 & -11.62 & -6.20 & $-6.59 * *$ & 54 & .45 \\
\hline 3 & $2-3$ & 3.16 & 13.16 & 1.77 & -0.39 & 6.72 & 1.78 & 54 & .06 \\
\hline
\end{tabular}

\section{Paired t-test for $8^{\text {th }}$ Graders}

There was a significant increase in mean attitude scores from Time $1(\mathrm{M}=122.21$, $\mathrm{SD}=21.07)$ to Time $2(\mathrm{M}=134.87, \mathrm{SD}=15.20), \mathrm{t}(51)=-7.37, \mathrm{p}=.000, \eta^{2}=.52$ indicating very large effect (Cohen, 1988 as cited in Pallant, 2005). Moreover, there was a significant difference in mean attitude scores between Time 1 $(\mathrm{M}=122.21, \mathrm{SD}=21.07)$ and Time $3(\mathrm{M}=133.44, \mathrm{SD}=16.43), \mathrm{t}(51)=-6.91$, $\mathrm{p}=.000, \eta^{2}=.48$ indicating very large effect (Cohen, 1988 as cited in Pallant, 2005). However, there was no significant difference in mean attitude scores between Time $2(M=134.87, S D=15.20)$ and Time $3(M=133.44, S D=16.43)$, $\mathrm{t}(51)=1.30, \mathrm{p}=.201, \eta^{2}=.03$ indicating small effect size (Cohen, 1988 as cited in Pallant, 2005).

Table 4.40: Paired T-test Results for $8^{\text {th }}$ Graders

\begin{tabular}{|c|c|c|c|c|c|c|c|c|c|}
\hline \multirow[b]{3}{*}{ Pair } & \multirow[b]{3}{*}{ Time } & \multicolumn{5}{|c|}{ Paired Differences } & \multirow[b]{3}{*}{$\mathrm{t}$} & \multirow[b]{3}{*}{ df } & \multirow[b]{3}{*}{$\eta^{2}$} \\
\hline & & \multirow[b]{2}{*}{ MD } & \multirow[b]{2}{*}{$\mathrm{SD}$} & \multirow[b]{2}{*}{$\mathrm{SE}$} & \multicolumn{2}{|c|}{$95 \% \mathrm{CI}$} & & & \\
\hline & & & & & $\begin{array}{c}\text { Lower } \\
\text { Limit }\end{array}$ & $\begin{array}{l}\text { Upper } \\
\text { Limit }\end{array}$ & & & \\
\hline 1 & $1-2$ & -12.65 & 12.38 & 1.72 & -16.10 & -9.21 & $-7.37 * *$ & 51 & .52 \\
\hline 2 & $1-3$ & -11.23 & 11.73 & 1.63 & -14.50 & -7.97 & $-6.91 * *$ & 51 & .48 \\
\hline 3 & $2-3$ & 1.42 & 7.91 & 1.10 & -0.78 & 3.63 & 1.30 & 51 & .03 \\
\hline
\end{tabular}


The estimated marginal means of attitude graph for different grades illustrated that all students' mean attitude scores significantly increased immediately after the visit. Furthermore, one week after the visit, students' mean attitude scores were still significantly higher than those before the visit even though those decreased. The overall change in mean attitude scores of students in different grade levels across the three time periods was statistically same. This result suggested that METU SC influences the different graders equally in changing their attitudes towards science. However, regardless of the research question, $6^{\text {th }}$ graders' mean attitude scores were significantly higher than $8^{\text {th }}$ graders'. The plot in Figure 4.10 suggested that students' grade levels are inversely proportional with their attitudes. In other words, when the grade levels increase, students' attitudes decrease.

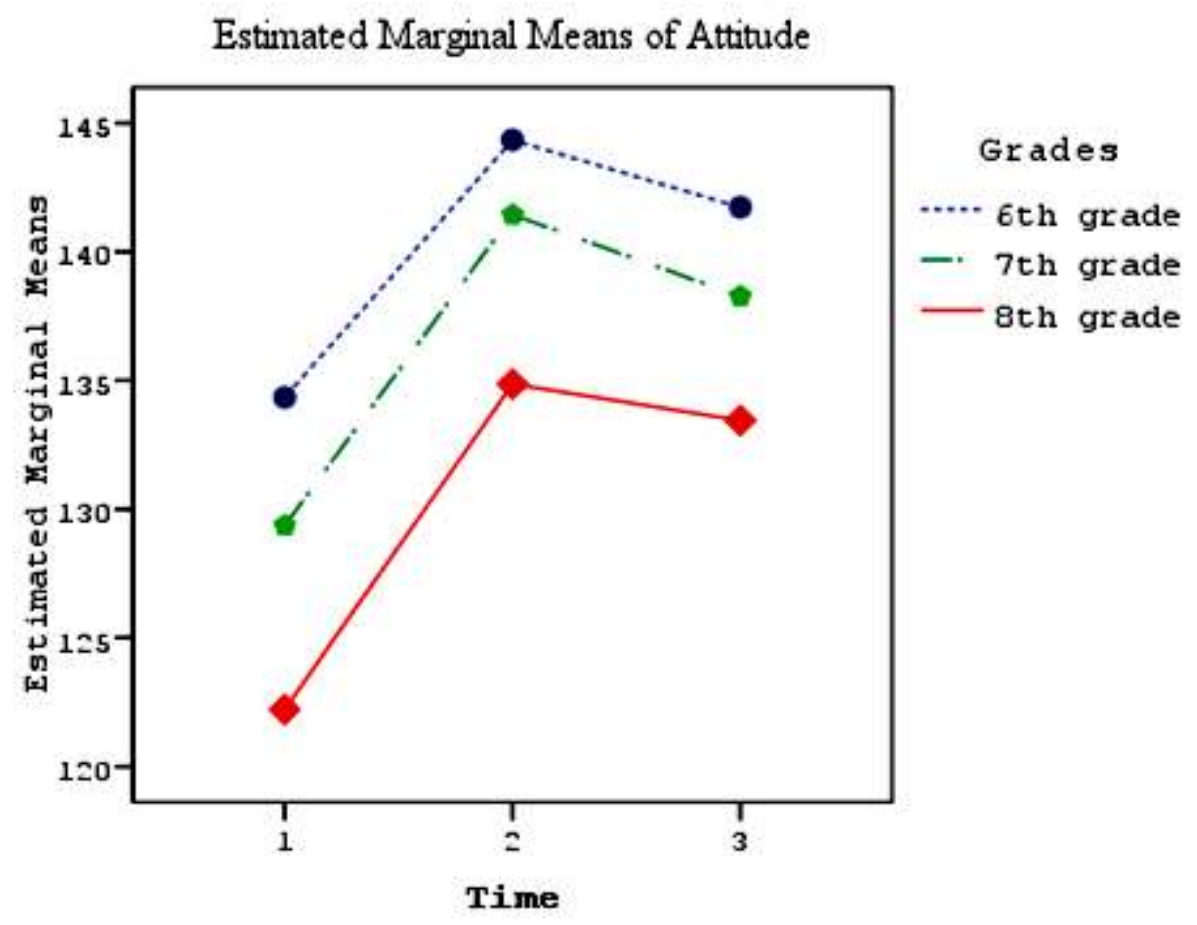

Figure 4.10: Estimated Marginal Means of Attitude across the Three Time Periods for Students in Different Grade Levels 


\subsubsection{Research Question 3}

Research Hypothesis: Overall attitudes towards science with respect to science $\underline{\text { achievement scores }}$

$\mathrm{H}_{31}$ : There is no change in mean attitude scores towards science over time.

$\mathrm{H}_{32}$ : There is no impact of science achievement scores (SAS) on students' mean attitude scores.

$\mathrm{H}_{33}$ : The change is not the same in mean attitude scores towards science over time for students with different science achievement scores (SAS).

The sample consisted of 159 students with the science achievements of average (47 students, 30.8\%), good (54 students, 34\%), and excellent (56 students, 35.2\%). The descriptive statistics for attitude scores over time were presented in Table 4.41.

Table 4.41: Descriptive Statistics of Attitude Scores for Students with Different Science Achievement Scores

\begin{tabular}{lcccc}
\hline & Grades & $\mathrm{M}$ & $\mathrm{SD}$ & $\mathrm{N}$ \\
\hline Time 1 & average & 120,84 & 18.54 & 49 \\
& good & 126,37 & 21.20 & 54 \\
& excellent & 137,70 & 19.73 & 56 \\
Time 2 & Total & 128,65 & 20.99 & 159 \\
& average & 133,45 & 16.54 & 49 \\
& good & 139,91 & 15.26 & 54 \\
Time 3 & excellent & 146,50 & 14.34 & 56 \\
& Total & 140,24 & 16.16 & 159 \\
& average & 131,16 & 18.19 & 49 \\
& good & 137,30 & 17.45 & 54 \\
& excellent & 144,16 & 17.75 & 56 \\
& Total & 137,82 & 18.45 & 159 \\
\hline
\end{tabular}


Mauchly's test indicated that the assumption of sphericity had not been violated $\left[\chi^{2}(2)=2.08 p=.353>.050\right]$; therefore sphericity assumed $\mathrm{F}$ test results for time and science achievement scores were used. A mixed-model analysis of variance revealed that the main effect for time was significant, $F(2,312)=81.47, p=.000$ $<.050, \eta^{2}=.34$ indicating a very large effect (Cohen, 1988 as cited in Pallant, 2005) (see Table 4.38). Hence, there was a difference in mean attitude scores over time.

A significant main effect for SAS was obtained, F $(2,156)=10.18$, $\mathrm{p}=.000<.050, \eta^{2}$ was equal to .12. It indicated a moderate effect (Cohen, 1988 as cited in Pallant, 2005) (see Table 4.38). This result showed that science achievement scores significantly influence mean attitude scores. Bonferroni pairwise comparisons result revealed that there was a significant difference in mean attitude scores between the students with science achievement of average $(\mathrm{M}=128.48, \mathrm{SE}=2.33)$ and the students with science achievement of excellent $(\mathrm{M}=142.79, \mathrm{SE}=2.18)$. The mean attitude score of students with science achievement of excellent was significantly higher than those of the students with science achievement of average. Similarly, there was a significant difference in mean attitude scores between the students with science achievement of good $(\mathrm{M}=134.53, \mathrm{SE}=2.22)$ and the students with science achievement of excellent $(\mathrm{M}=142.79, \mathrm{SE}=2.18)$. The mean attitude score of students with science achievement of excellent was significantly higher than those of the students with science achievement of good. However, there was no significant difference in mean attitude scores between the students with science achievement of average $(\mathrm{M}=128.48, \mathrm{SE}=2.33)$ and the students with science achievement of good $(\mathrm{M}=134.53, \mathrm{SE}=2.22)$.

However, there was no significant time*SAS interaction effect, $F(4,312)=1.51$, $\mathrm{p}=.198>.050, \eta^{2}=.02$ indicating a small effect (Cohen, 1988 as cited in Pallant, 2005) (see Table 4.38). This result suggested that the overall change in mean 
attitude scores of students with different science achievement scores over time is statistically same.

Table 4.42: Analysis of Variance Results for Effects

\begin{tabular}{cccccc}
\hline Source & SS & df & MS & F & $\eta^{2}$ \\
\hline Between subjects & & & & & \\
SAS & 5435.79 & 2 & 2717.89 & $10.18^{* *}$ & .12 \\
Error & 41635.80 & 156 & 266.90 & & \\
Within Subjects & & & & & \\
Time & 11988.63 & 2 & 5994.32 & $81.47^{* *}$ & .34 \\
Time*SAS & 445.31 & 4 & 111.33 & 1.51 & .02 \\
Error & 22955.89 & 312 & 73.58 & & \\
\hline
\end{tabular}

In the lights of information given above, all proposed hypotheses were rejected. In order to determine the change in mean attitude scores of students with different science achievement scores over time, paired t-tests were conducted for students having different grades.

\section{Paired t-test for Students with Science Achievement of Average}

There was a significant increase in mean attitude scores from Time $1(\mathrm{M}=120.84$, $\mathrm{SD}=18.54)$ to Time $2(\mathrm{M}=133.45, \mathrm{SD}=16.54), \mathrm{t}(48)=-5.52, \mathrm{p}=.000, \eta^{2}=.39$ indicating very large effect (Cohen, 1988 as cited in Pallant, 2005). Besides, there was a significant difference in mean attitude scores between Time $1(\mathrm{M}=120.84$, $\mathrm{SD}=18.54)$ and Time $3(\mathrm{M}=131.16, \mathrm{SD}=18.19), \mathrm{t}(48)=-6.86, \mathrm{p}=.000, \eta^{2}=.50$ indicating very large effect (Cohen, 1988 as cited in Pallant, 2005). However, there was no significant difference in mean attitude scores between Time $2(\mathrm{M}=133.45$, $\mathrm{SD}=16.54)$ and Time $3(\mathrm{M}=131.16, \mathrm{SD}=18.19), \mathrm{t}(48)=1.12, \mathrm{p}=.266, \eta^{2}=.03$ indicating small effect size (Cohen, 1988 as cited in Pallant, 2005). 
Table 4.43: Paired T-test Results for Students with Science Achievement of Average

\begin{tabular}{|c|c|c|c|c|c|c|c|c|c|}
\hline \multirow[b]{3}{*}{ Pair } & \multirow[b]{3}{*}{ Time } & \multicolumn{5}{|c|}{ Paired Differences } & \multirow[b]{3}{*}{$\mathrm{T}$} & \multirow[b]{3}{*}{ df } & \multirow[b]{3}{*}{$\eta^{2}$} \\
\hline & & \multirow[b]{2}{*}{ MD } & \multirow[b]{2}{*}{ SD } & \multirow[b]{2}{*}{ SE } & \multicolumn{2}{|c|}{$95 \% \mathrm{CI}$} & & & \\
\hline & & & & & $\begin{array}{l}\text { Lower } \\
\text { Limit }\end{array}$ & $\begin{array}{l}\text { Upper } \\
\text { Limit }\end{array}$ & & & \\
\hline 1 & $1-2$ & -12.61 & 15.99 & 2.28 & -17.21 & -8.02 & $-5.52 * *$ & 48 & .39 \\
\hline 2 & $1-3$ & -10.33 & 10.54 & 1.51 & -13.35 & -7.30 & $-6.86^{* *}$ & 48 & .50 \\
\hline 3 & $2-3$ & 2.29 & 14.23 & 2.03 & -1.80 & 6.37 & 1.12 & 48 & .03 \\
\hline
\end{tabular}

\section{Paired t-test for Students Having with Science Achievement of Good}

There was a significant increase in mean attitude scores from Time $1(\mathrm{M}=126.37$, $\mathrm{SD}=21.20)$ to Time $2(\mathrm{M}=139.91, \mathrm{SD}=15.26), \mathrm{t}(53)=-7.79, \mathrm{p}=.000, \eta^{2}=.53$ indicating very large effect (Cohen, 1988 as cited in Pallant, 2005). Furthermore, there was a significant difference in mean attitude scores between Time 1 $(\mathrm{M}=126.37, \mathrm{SD}=21.20)$ and Time $3(\mathrm{M}=137.30, \mathrm{SD}=17.45), \mathrm{t}(53)=-5.94$, $\mathrm{p}=.000, \eta^{2}=.40$ indicating very large effect (Cohen, 1988 as cited in Pallant, 2005). However, there was no significant difference in mean attitude scores between Time $2(\mathrm{M}=139.91, \mathrm{SD}=15.26)$ and Time $3(\mathrm{M}=137.30, \mathrm{SD}=17.45)$, $\mathrm{t}(53)=1.95, \mathrm{p}=.057, \eta^{2}=.07$ indicating moderate effect size (Cohen, 1988 as cited in Pallant, 2005). 
Table 4.44: Paired T-test Results for Students with Science Achievement of Good

\begin{tabular}{|c|c|c|c|c|c|c|c|c|c|}
\hline \multirow[b]{3}{*}{ Pair } & \multirow[b]{3}{*}{ Time } & \multicolumn{5}{|c|}{ Paired Differences } & \multirow[b]{3}{*}{$\mathrm{t}$} & \multirow[b]{3}{*}{ df } & \multirow[b]{3}{*}{$\eta^{2}$} \\
\hline & & \multirow[b]{2}{*}{ MD } & \multirow[b]{2}{*}{ SD } & \multirow[b]{2}{*}{ SE } & \multicolumn{2}{|c|}{$95 \% \mathrm{CI}$} & & & \\
\hline & & & & & $\begin{array}{l}\text { Lower } \\
\text { Limit }\end{array}$ & $\begin{array}{l}\text { Upper } \\
\text { Limit }\end{array}$ & & & \\
\hline 1 & $1-2$ & -13.54 & 12.77 & 1.74 & -17.02 & -10.05 & $-7.79 * *$ & 53 & .53 \\
\hline 2 & $1-3$ & -10.93 & 13.52 & 1.84 & -14.62 & -7.24 & $-5.94 * *$ & 53 & .40 \\
\hline 3 & $2-3$ & 2.61 & 9.86 & 1.34 & -0.08 & 5.30 & 1.95 & 53 & .07 \\
\hline
\end{tabular}

Paired t-test for Students Having with Science Achievement of Excellent

There was a significant increase in mean attitude scores from Time $1(\mathrm{M}=137.70$, $\mathrm{SD}=19.73)$ to Time $2(\mathrm{M}=146.50, \mathrm{SD}=14.34), \mathrm{t}(55)=-7.14, \mathrm{p}=.000, \eta^{2}=.45$ indicating very large effect (Cohen, 1988 as cited in Pallant, 2005). Moreover, there was a significant difference in mean attitude scores between Time 1 $(\mathrm{M}=137.70, \mathrm{SD}=19.73)$ and Time $3(\mathrm{M}=144.16, \mathrm{SD}=17.75), \mathrm{t}(55)=-4.33$, $\mathrm{p}=.000, \eta^{2}=.28$ indicating very large effect (Cohen, 1988 as cited in Pallant, 2005). However, there was no significant difference in mean attitude scores between Time $2(\mathrm{M}=146.50, \mathrm{SD}=14.34)$ and Time $3(\mathrm{M}=144.16, \mathrm{SD}=17.75)$, $\mathrm{t}(55)=1.61, \mathrm{p}=.114, \eta^{2}=.05$ indicating small effect size (Cohen, 1988 as cited in Pallant, 2005).

Table 4.45: Paired T-test Results for Students with Science Achievement of Excellent

\begin{tabular}{|c|c|c|c|c|c|c|c|c|c|}
\hline \multirow[b]{3}{*}{ Pair } & \multirow[b]{3}{*}{ Time } & \multicolumn{5}{|c|}{ Paired Differences } & \multirow[b]{3}{*}{$\mathrm{t}$} & \multirow[b]{3}{*}{$\mathrm{df}$} & \multirow[b]{3}{*}{$\eta 2$} \\
\hline & & \multirow[b]{2}{*}{$\mathrm{MD}$} & \multirow[b]{2}{*}{$\mathrm{SD}$} & \multirow[b]{2}{*}{$\mathrm{SE}$} & \multicolumn{2}{|c|}{$95 \% \mathrm{CI}$} & & & \\
\hline & & & & & $\begin{array}{c}\text { Lower } \\
\text { Limit }\end{array}$ & $\begin{array}{l}\text { Upper } \\
\text { Limit }\end{array}$ & & & \\
\hline 1 & $1-2$ & -8.80 & 9.22 & 1.23 & -11.27 & -6.33 & $-7.14 * *$ & 55 & .45 \\
\hline 2 & $1-3$ & -6.46 & 11.16 & 1.49 & -9.45 & -3.48 & $-4.33 * *$ & 55 & .28 \\
\hline 3 & $2-3$ & 2.34 & 10.90 & 1.46 & -0.58 & 5.26 & 1.61 & 55 & .05 \\
\hline
\end{tabular}


The estimated marginal means of attitude graph for students with different science achievement scores illustrated that all students' mean attitude scores significantly increased immediately after the visit. Furthermore, one week after the visit, students' mean attitude scores were still significantly higher than those before the visit even though those decreased. The overall change in mean attitude scores of students with different science achievement scores over time was statistically same. This result suggested that METU SC influences the students with different science achievement scores equally in changing their attitudes towards science. However, regardless of the research question, the students with science achievement of excellent significantly obtained higher attitude scores than those with science achievement of average. The plot also suggested that students' science achievement scores are directly proportional with their attitudes towards science. In other words, when the students' science achievement scores increase, students' attitudes towards science increase (Figure 4.11).

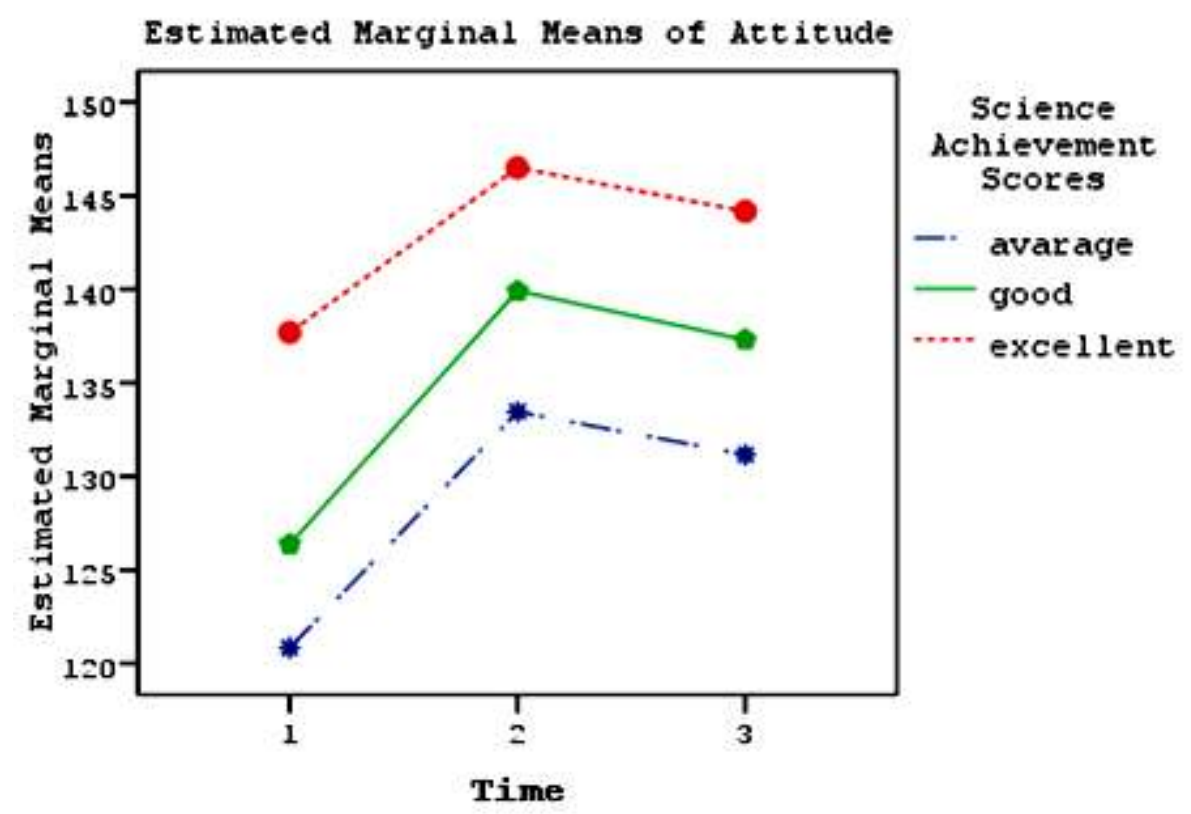

Figure 4.11: Estimated Marginal Means of Attitude over the Three Time Periods for Students with Different Science Achievement Scores 


\section{CHAPTER 5}

\section{DISCUSSION, CONCLUSION, IMPLICATIONS, AND RECOMMENDATIONS FOR FUTURE RESEARCH}

The purpose of the present study was to indentify the impact of METU SC on students' attitudes towards science as well as with respect to students' gender, grade levels, and science achievement scores. This chapter includes two sections. The research findings are summarized and discussed in the first section. The implications of the study and recommendations for future research are presented in the second section.

\subsection{Discussion}

In this section the findings are summarized and discussed.

\subsubsection{Attitudes towards science}

The current study has highlighted a variety of issues concerning $6^{\text {th }}, 7^{\text {th }}$ and $8^{\text {th }}$ graders' attitudes towards science. The results of Design 1 and Design 2 explicitly showed that METU SC is effective in changing primary education students' overall attitudes towards science in positive way. These results are consistent with the findings in the literature (e.g., Jarvis \& Pell, 2002, 2005; Rennie \& 
McClafferty, 1995; Rix \& McSorley, 1999). The literature suggests that connecting the scientific ideas to students' everyday experiences, providing them to interact with exciting exhibits that might not be in their school laboratories, letting them to engage in, and explore scientific phenomena and discuss these experiences with their friends increase their attitudes towards science (Bozdoğan \& Yalçın, 2006, 2009; Carlisle, 1995 as cited in Rennie \& McClafferty, 1995; Moris, 1990). Several researchers pointed out that the positive changes in visitors' attitudes are significant, and many research studies indicated that science centres affect their visitors' attitudes positively maintaining throughout long period (Gammon, 2007; Jarvis \& Pell, 2002, 2005). However, even though retention test was administered one week after the visit to METU SC, students' overall attitudes towards science declined. Jarvis and Pell (2005) pointed out that even though there was a significant impact of visit to science centre on students' attitudes, in-depth interviews with the students revealed that this positive impact was undermined by negative school experiences at a later time.

\subsubsection{Attitudes towards science with respect to constructs of the attitude scale}

One particular advantage of the current study is that different constructs of attitudes towards science have been measured and analyzed separately. Previous studies focusing on attitude towards science have pointed out that the lack of clarity on attitudes towards science measures blurs the actual effect or relation of different types of variables to this construct (Barmby et al., 2008). By using different dimensions of the attitudes towards science, this study generated more detailed and clearer arguments about the effect of METU SC on students' attitudes. While METU SC had a positive impact on students' attitudes towards four of the six constructs of the attitude scale that are self-concept in school science, science outside of the school, future participation in science, and importance of science, it did not have an impact on students' attitudes towards two constructs of the attitude scale that are learning science in school and practical work in school science. From 
this result the researchers speculate that the impact of METU SC on students' school related attitudes towards science is very limited.

\subsubsection{Attitudes towards science with respect to gender}

Even though there are many investigations about gender difference on students' attitudes towards science, the literature on this subject is still inconclusive. While some studies showed that boys' attitudes towards science are significantly more positive than girls (Catsambis, 2006; Francis \& Greer, 1999; Weinburgh, 1995), the others concluded that girls feel confident of their attainment to take science classes, and they do well as much as boys in the traditionally 'masculine' subjects (Harvard, 1996). However, some studies showed that there was no gender difference in students' attitudes towards science (e.g., Çakır et al., 2007; Sorge et al., 2000). METU SC had a positive impact on both female and male students' attitudes towards science and this impact was also equal for both groups. Girls started with more positive attitudes than boys. Even though both boys and girls increased their attitude scores on the post-test, girls obtained more improvement in attitude scores than boys. Their attitudes towards science were more positively affected by the visit to METU SC than boys'. This result was consistent with the findings of Barmby et al. (2008) and Sorge et al. (2000) but opposite to the findings of George (2000, 2006). In the study of Baker \& Leary (1995), 40 girls reported that they liked learning science in the interactive social context rather than participating activities that isolated them (e.g., independent writing, reading or note-taking). Similar findings obtained from the ROSE (Relevance of Science Education) project in which 40 countries (including Turkey) participated. As a result of this study, Jenkins \& Pell (2006) reported that helping the other people is more important for girls than boys. METU SC provided girls with 'peer- teaching' and 'social interaction'. For this reason, their attitudes towards science may have increased more on the post-test than boys. One week after the visit, both boys' and girls' attitudes towards science decreased. Furthermore, girls' attitudes declined 
faster. This result was consistent with the findings of Barmby et al. (2008) and Sorge et al. (2000) but opposite to the findings of George (2000, 2006). The sharp decline in girls' attitudes may be related to their experience in school science and their perception about it, such as male-domination and lack of social interaction.

\subsubsection{Attitudes towards science with respect to grade levels}

The results revealed that METU SC has a significant and equal impact on the attitudes of students in different grade levels. However, the result showed that there was a significant difference in mean attitude scores between the $6^{\text {th }}$ and $8^{\text {th }}$ graders and students' grade levels were inversely proportional with their attitudes towards science. In other words, when the grade levels increase, students' attitudes decrease. This finding was consistent with the findings by Barmby et al., 2008; Baykul, 1990; Çakır et al., 2007; Coughlan, 2000; Francis \& Greer, 1999; George, 2000, 2006; Osborne et al., 2003; Reid, 2003).

\subsubsection{Attitudes towards science with respect to science achievement scores}

The results revealed that METU SC has a significant and equal impact on the attitudes of students with different science achievement scores. However, there was a significant difference in mean attitude scores between the students with the science achievement of average and those with the science achievement of excellent, and students' science achievement scores were directly proportional with their attitudes. In other words, when the science achievement scores increase, students' attitudes increase. This finding was consistent with the findings of Karaer (2007) and Mattern and Schau (2002).

\subsection{Conclusion, Implications, and Recommendations for Future Research}

The uses of science centres in order to improve students' knowledge, skills, and attitudes related to science have been largely neglected by teachers, families, and 
schools (Lucas, 1983; Ramey-Gassert, 1997). However, similar to many other studies (e.g., Jarvis \& Pell, 2002, 2005; Rennie \& McClafferty, 1995; Rix \& McSorley, 1999; Russell, 1990; Wellington, 1990), METU SC had a significant impact on students' attitudes towards science without regard to their gender, grade levels, and science achievement scores. . Hudson \& Freeman (1983) proposed that the contemporary science and scientists presented to young children have a great deal of importance in forming primary education students' attitudes towards science as well as determining their future career choice (as cited in Eshach, 2007). Furthermore, positive attitudes towards science are essential for primary education students due to the fact that many latent scientists seemed to decide about their future careers in their early ages (Blatchford, 1992; Musgrove \& Batcock, 1969; Woolnough, 1990 as cited in Jarvis \& Pell, 2005; Moris, 1990). The one aspect that is clear is that science centres have the potential to develop positive attitudes towards science. For this one reason alone, science centres are considered as a useful resource in the development of students' science education. Therefore, it is highly recommended that schools, teachers, and families should benefit from science centres. Perhaps, a protocol should be signed between science centres and the National Ministry of Education in order to make schools visit science centres, even if it is once in a year. Furthermore, science centres' program associated with primary education curriculum should be developed, and teachers should be aware of how they integrate school science with the science presented in science centres.

While METU SC had a significant positive impact on students' attitudes towards four of the six constructs of the attitude scale that are self-concept in school science, science outside of the school, future participation in science, and importance of science, it did not have an impact on students' attitudes towards two constructs of the attitude scale that are learning science in school and practical work in school science. The main recommendation for future research is to investigate the reasons of why science centres have not impact on students' attitudes towards school science. This study should be replicated with different 
samples for the sake of generalizing the results. This study should also be replicated with use of different time intervals. Finally, this study should be extended with a qualitative examination to generate detailed analysis about the reasons of why and how science centres effects students' attitudes towards science and which elements of science centres are more essential for this effect. 


\section{REFERENCES}

Albayrak, A. S. (2006). Uygulamalı çok değişkenli istatistik teknikleri. Ankara: Asil Yayinevi.

Allen, S. (2002). Looking for learning in visitor talk: A methodological exploration. In G. Leinhardt, K. Crowley, \& K. Knutson, Learning conversations in museums (pp. 259-303). Mahwah, NJ: Lawrance Erlbaum Association.

Alvarez, J. M. (2009). Self-concept. Retrieved August 03, 2009, from Social Issues Reference: http://social.jrank.org/pages/554/SelfConcept.html\#ixzz0N7Fn1mUr

Anderson, D., Lucas, K. B., Ginns, I. S., \& Dierking, L. D. (2000). Development of knowledge about electricity and magnetism during a visit to a science museum and related post-visit activities. Science Education, 84(5), 658-679.

Atılgan, H., Doğan, N., \& Kan, A. (2006). Ĕgitimde ölçme ve değerlendirme. (H. Atılgan, Ed.) Ankara: Anı Yayıncılık.

Azjen, I. (2001). Nature and operation of attitudes. Annual Review of Psychology, $52,27-58$.

Azjen, I., \& Fishbein, M. (2000). Attitudes and the attitude-behavior relation: Reasoned and automatic processes. European Review of Social Psychology, , 11(1), 1-33.

Baker, D., \& Leary, R. (1995). Letting girls speak out about science. Journal of Research in Science Teaching , 32(1), 3-27.

Barmby, P., Kind, P. M., \& Jones, K. (2008). Examining changing attitudes in secondary school science . International Journal of Science Education , 30(8), 1075-1093. 
Baykul, Y. (1990). To what extent the students' attitudes towards mathematics and science subjects were changed in the Turkish schools in grades five through eleven, the factors which might have some significant relation with the student performance in student selection exam. Ankara, Turkey: ÖSYM Yayınları.

Beiers, R., \& McRobbie, C. (1992). Learning in interactive science centres. Research in Science Education, 22(1), 38-44.

Borg, W. R., \& Gall, M. D. (1979). Educational research an introduction. New York: Longman Inc.

Botelho, A., \& Ana, M. M. (2006). Students-exhibits interaction at a science centre. Journal of Research in Science Teaching , 43(10), 987-1018.

Bozdoğan, A. E., \& Yalçın, N. (2006). Bilim merkezlerinin ilköğretim öğrencilerinin fene karşı ilgi düzeylerinin değişmesine ve akademik başarılarına etkisi: Enerji parkı. Ege Eğitim Dergisi , 7(2), 95-114.

Bozdoğan, A. E., \& Yalçın, N. (2009). Determining the influence of a science exhibition center training program on elementary pupils' interest and achievement in science. Eurasia Journal of Mathematics, Science \& Technology Education, 5(1), 27-34.

Bradburne, J. M. (1998). Dinosaurs and white elephants: The hands-on science center in the twenty-first century. Public Understanding of Science , 7(3), 237253.

Cajas, F. (1999). Public undertanding of science: Using technology to enhance school science in everday life. International Journal of Science Education, 21(7), 765-773.

Cajas, F. (1998). Using out-of-school ecperience in science lessons: An impossible task? International Journal of Science Education , 20(5), 623-625.

Canadian Association of Science Centres. (2008). Step up Canada! A Science \& Technology Engagement Program for all Canadians. Ontario, CANADA: Canadian Association of Science Centres (CASC). 
Catsambis, S. (1995). Gender, race, ethnicity, and science education in the middle grades. Journal of Research in Science Teaching, 32(3), 243-257.

Colman, A., \& Pulford, B. (2006). A crash course in Spss for Windows updated for versions 10, 11, 12 and 13 (3rd ed.). Oxford: Blackwell.

Coughlan, R. (2000). European union physics colloquium. Physics Education, 35(4), 287-291.

Crano, W. D., \& Prislin, R. (2006). Attitudes and persuasion. Annual Review of Psychology, 57, 345-374.

Çakır, N. K., Şenler, B., \& Taşkın, B. G. (2007). İlköğretim II. kademe öğrencilerinin fen bilgisi dersine yönelik tutumlarinin belirlenmesi. Türk Eğitim Bilimleri , 5(4), 637-655.

Davies, K. (1997). The challenge of materials gallery: A new exhibition at the science museum. New Materials , 169-172.

Demirelli, H., Kavak, N., \& Tufan, Y. (2006). Fen-Teknoloji okuryazarlığı ve informal fen eğitimi: gazetelerin potansiyel rolü. Gazi Ĕgitim Fakültesi Dergisi , 26(3), 17-28.

Ebenezer, J. V., \& Zoller, U. (1993). Grade 10 students' perceptions of and attitudes toward science teaching and school science. Journal of Research in Science Teaching , 30, 175-186.

Eshach, H. (2007). Bridging in-school and out-of-school learning: Formal, nonformal, and informal education. Journal of Science Education and Technology , 16(2), 171-190.

European Network of Science Centres and Museums. (2008). The impact of Science \& Discovery Centres: A review of worldwide studies. Retrieved July 13, 2009, from European Network of Science Centres and Museums (EXCITE): http://www.ecsite-uk.net/reports/downloads/impact-of-sciencediscovery-centres-review-of-worldwide-studies.pdf 
Falk, J. H., \& Dierking, L. D. (1992). The museum experience. Washington, D.C.: Whalesback Books.

Field, A. (2005). Discovering statistics using spss. London: SAGE Publications Ltd.

Fraenkel, J. R., \& Wallen, N. E. (1932). How to design evaluate research in education (6th ed.). New York: McGraw-Hill Companies, Inc.

Francis, L. J., \& Greer, J. E. (1999). Measuring attitude towards science among secondary school students: The affective domain. Research in Science \& Technological Education, 17(2), 219-226.

Gammon, B. (2007). The impact of Science \& Discovery Centres: A review of worldwide studies. (E. Kell, Ed.) Retrieved February 13, 2009, from Association for Science and Discovery Centres: http://sciencecentres.org.uk/reports/impact-of-science-discovery-centres.html

Garnett, R. (2002). The impact of science centers/museums on their surrounding communities: Summary report. Retrieved 18 September, 2008, from The Association of Science-Technology Centers (ASTC): www.astc.org/resource/case/Impact_Study02.pdf

George, R. (2000). Measuring change in students' attitudes toward science over time: An application of latent variable growth modeling. Journal of Science Education and Technology, 9(3), 213-225.

George, R. (2006). A cross-domain analysis of change in students' attitudes toward science and attitudes about the utility of science. International Journal of Science Education , 28(6), 571-589.

Germann, P. J. (1988). Development of the attitude toward science in school assessment and its use to investigate the relationship between science achievement and attitude toward science in school. Journal of Research in Science Teaching, 25(8), 689-703.

Gezer, K., Köse, S., \& Bilen, K. (2007). 6. sınıf öğrencilerin fen bilgisine yönelik tutumları (Buldan örneği). Erzincan Ĕgitim Fakültesi , 63-120. 
Hair, J. F., Anderson, R. E., Tatham, R. L., \& William, C. B. (1995). Multivariate analysis with readings (4 ed.). London: Collier McMillen.

Harvard, N. (1996). Student attitudes to studying a-level sciences. Public Understanding of Science , 5(4), 321-330.

Henriksen, E. K., \& Frǿyland, M. (2000). The contribution of museums to scientific literacy: Views from audience and museum professionals. Public Understanding of Science , 9, 393-415.

Hooper-Greenhill, E., Dodd, J., Gibson, L., Phillips, M., Jones, C., \& Sullivian, E. (2005, April). What did you learn at the museum today? Second study.

Retrieved September 17, 2008, from University of Leicester, Research Centre for Museums and Galleries:

http://www.le.ac.uk/ms/research/Reports/Whatdidyoulearn2.pdf

House of Lords. (2000). Chapter 6: Science education in schools (3rd report of the select committee on science and technology). Retrieved July 13, 2009, from United Kingdom Parliament:

http://www.publications.parliament.uk/pa/ld199900/ldselect/ldsctech/38/3809. htm\#a53

Huitt, W. (2004). Self-concept and Self-esteem. Retrieved August 3, 2009, from Educational Psychology Interactive. Valdosta, GA: Valdosta State University: http://chiron.valdosta.edu/whuitt/col/regsys/self.html

Jarvis, T., \& Pell, A. (2002). Effect of the challenger experience on elementary children's attitudes to science. Journal of Research in Science Teaching , 39(10), 979-1000.

Jarvis, T., \& Pell, A. (2005). Factor influencing elementary school children's attitudes toward science before, during, and after a visit to the UK National Space Centre. Jornal of Research in Science Teaching , 42(1), 53-58.

Jenkins, E. W., \& Pell, R. G. (2006). The Relevance of Science Education Project (ROSE) in England: a summary of findings. Retrieved November 13, 2009, from The Relevance of Science Education:

http://www.ils.uio.no/english/rose/network/countries/uk-england/rose-reporteng.pdf 
Jones, M. G., Howe, A., \& Rua, M. J. (2000). Gender differences in students' experiences, interests, and attitudes toward science and scientisits. Science Education , 54, 180-192.

Karaer, H. (2007). İlköğretim ikinci kademe 8. sinif öğrencilerinin fen bilgisi dersine yönelik turumlarinin bazı değişkenler açısından incelenmesi. Erzincan Ĕ̈itim Fakültesi , 107-119.

Kelly, J. (2000). Rethinking the elementary science methods course: A case for content, pedagogy, and informal science education. Intenational Journal of Science Education , 22, 755-777.

Kind, P., Jones, K., \& Barmby, P. (2007). Developing attitudes towards science measures . International Journal of Science Education , 29(7), 871-893.

Lucas, A. M. (1983). Scientific literacy and informal learning. Studies in Science Education , 10(1), 1- 36.

Lyons, T. (2006). Diffirent countries, same science classes: Students' experiences of school science in their own words. International Journal of Science Education , 28, 591-613.

Mattern, N., \& Schau, C. (2002). Gender differences in science attitudeachievement relationships over time among white middle-school students. Journal of Research in Science Teaching, 39(4), 324-340.

Matthews, P. (2007). The Relevance of Science Education in Ireland. Retrieved November 7, 2009, from The Relevance of Science Education: http://www.ils.uio.no/english/rose/network/countries/ireland/irl-matthewsrose-report.pdf

Mayoh, K., \& Knutton, S. (1997). Using out-of-school ecperience in science lessons: Reality or rhetoric? International Journal of Science Education, 19(7), 849-867.

McManus, P. (1992). Topics in museums and science education. Studies in Science Education , 20, 157-182. 
Moris, C. (1990). Importing 'Hands-On' science into schools: The Light Works Van Programme. Physics Education , 263-266.

Morris Hargreaves McIntrye. (2005). Never mind the witdth feel the quality. Retrieved August 17, 2009, from Morris Hargreaves McIntrye Consultancy and Research:

http://www.lateralthinkers.com/Resources/MHM_PDFs/museums_and_herita ge.pdf

National Research Council. (1996). National science education standards. Washington, DC: National Academy Press.

Nieswandt, M. (2005). Attitudes towards science: A review of the field. In S. Alsop, Beyond cartesian dualism: Encountering affect in the teaching and learning of science (pp. 41-52). Dordrecht: Springer.

ODTÜ. (n.d.). Orta Doğu Teknik Üniversitesi Toplum ve Bilim Uygulama ve Araştırma Merkezi yönetmeliği. Retrieved June 25, 2009, from T.C. Resmi Gazete: http://www.resmi-gazete.org/sayi/8887/orta-dogu-teknik-universitesitoplum-ve-bilim-uygulama-ve-arastirma-merkezi-yonetmeligi.html

Ogawa, R. T., Loomis, M., \& Crain, R. (2008). Institutional history of an interactive science center: The founding and development of the Exploratorium . Science Education , 1-24.

Osborne, J., Simon, S., \& Collins, S. (2003). Attitudes towards science: A review of the literature and its implications. International Journal of Science Education, 25(9), 1049-1079.

Pace, S., \& Tesi, R. (2004). Adults' perception of field trips taken within grades K12: Eight case studies in the New York metropolitan area. Education , 125(1), $30-40$.

Pallant, J. (2005). SPSS survival manual (second ed.). Berkshire: Open University Press.

Pearce, S. (1996). Exploring science in museums. London: Athlone Press. 
Pedretti, E. (2002). T. Kuhn Meets T. Rex: Critical conversations and new directions in science. Studies in Science Education, 37(1), 1-41.

Pedretti, E. (2004). Perspectives on learning through research on critical issuesbased science centres exhibitisons. Science Education , 88, 34-47.

Persson, P. E. (1996). Science centres: Dedicated to inquiry and exploration. Physics World, 9(7), 55-56.

Persson, P. E. (2000a). Science centers are thriving and going strong! Public Understanding of Sceince , 449-460.

Persson, P. E. (2000b). The changing science center: Sustaining our mission into the $21^{\text {st }}$ century. Retrieved July 5, 2009, from The Association of ScienceTechnology Centers Incorporated (ASTC): http://www.astc.org/pubs/dimensions/2000/jan-feb/changing.htm

Pompea, S., \& Hawkins, I. (2002). Increasing science literacy in optics and photonics trough science centres, museums, and web-based exhibits. Seventh International Conference on Education and Training in Optics and Photonics (pp. 554-560). OSA and SPIE.

Quin, M. (1990). What is hands-on science, and where can I find? Physics Education , 25, 258-262.

Ramey-Gassert, L. (1996). Same place, different experiences: Exploring the influence of gender students' science museum experiences. International Journal of Science Education , 18, 903-912.

Ramey-Gassert, L. (1997). Learning science beyond the classroom. The Elementary School Journal , 97(4), 433-450.

Ramey-Gassert, L., Walberg, H. J., \& Walberg, H. J. (1994). Reexamining connections: Museums as science learning environments. Science Education, $78,345-363$.

Rebecca, W. M. (2007). Applied statistics: From bivariate through multivariate techniques. Thousands Oaks, CA: SAGE Publications. 
Reid, N. (2003). Gender and physics. International Journal of Science Education, 25(4), 509-536.

Reid, N. (2006). Thoughts on attitude measurement. Research in Science and Technological Education , 24(1), 3-27.

Rennie, L. J., \& McClafferty, T. P. (1995). Using visits to Interactive Science and Technology Centres, Museums, Aquaria, and Zoos to promote learning in science. Journal of Science Teacher Education , 6(4), 175-185.

Rennie, L. J., \& McClafferty, T. P. (1996). Science centres and science learning. Studies in Science Education, 27, 53-98.

Rix, C., \& McSorley, J. (1999). An investigation into the role that school-based interactive science centers may play in the education of primary-aged children. Science Education , 21(6), 577-593.

Russell, I. (1990). Visiting a science centre: What's on offer? Physics Education, $25,258-262$.

Salmi, H. (2003). Science centres as learning laboratories: Experiences of Heureka, the Finnish Science Centre. International Journal of Technology Management , 25(5), 460-476.

Semper, R. (2007). Science centers at 40: Middle-aged maturity or mid-life crisis. Curator, 50(1), 147-150.

Serin, O., \& Mohammadzadeh, B. (2008). The relationship between primary school students' attitudes towards science and their science achievement (Sampling: Izmir). Cypriot Journal of Educational Sciences , 2(6), 68-75.

Shortland, M. (1987). No business like show business. Nature, 328, 213-214.

Sjǿberg, S., \& Schreiner, C. (2005, March 8-11). Young people and science attitudes, values and priorities: Evidence from the ROSE project. Retrieved July 5, 2009, from European Commission Public Opinion:

http://www.ec.europa.eu/public_opinion/flash/fl_239_en.pdf 
Sorge, C., Newsom, H. E., \& Hagerty, J. J. (2000). Fun is not enough: Attitudes of Hispanic middle school students toward science and scientists. Hispanic Journal of Behavioral Sciences , 22(3), 332-345.

Stevens, J. (1996). Applied multivariate statistics for the social sciences (3rd ed.). Mahwah, N.J.: Lawrence Erlbaum Associates.

Stevens, J. (2002). Applied multivariate statistics for the social sciences (4th ed.). Mahwah, N.J.: Lawrence Erlbaum Associates.

Stevenson, J. (1994). 'The philosophy behind Launch Pad', science museum. Journal of Education and Museums , 8, 10-18.

Tabachnick, B. G., \& Fidell, L. S. (2001). Using multivariate statistics (4th ed.). Needham Heights, MA: Allyn and Bacon.

Talim Terbiye Kurulu Başkanlığı. (2008a). Eğitime yeni bir soluk: Müzeler. Retrieved May 21, 2009, from Talim Terbiye Kurulu Başkanlığı: http://ttkb.meb.gov.tr/yenicalismalar/muze/muze.htm

Talim Terbiye Kurulu Başkanlığ1. (2008b). İlköğretim 1-8. Sinıflar Türkçe, Matematik, Sosyal Bilgiler, Hayat Bilgisi ile Fen ve Teknoloji dersi ögretim programlarında müze ile eğitim. Retrieved January 1, 2008, from Talim Terbiye Kurulu Başkanlığı: http://ttkb.meb.gov.tr/yenicalismalar/muze/muzeprmgr.pdf

The Association of Science-Technology Centres (ASTC). (n.d.). About science centre. Retrieved from The Association of Science-Technology Centres: http://www.astc.org/sciencecenters/index.htm

The Scientific and Technological Research Council of Turkey. (2008, March 3). Bilim merkezleri. Retrieved January 19, 2009, from The Scientific and Technological Research Council of Turkey (TÜBİTAK) : http://www.tubitak.gov.tr/home.do?ot=5\&rt=12\&rid=9424\&pid=461\&cid=94 $20 \& \operatorname{sid}=934$

Vygotsky, L. S. (1978). Mind in society: Development of higher psychological processes. Cambridge, MA: Harvard University Press. 
Walker, C. L., \& Rakow, S. J. (1985). The status of Hispanic American students in science: Attitudes. Hispanic Journal of Behavioral Sciences , 7(3), 225-245.

Walton, R. (2000). Heidegger in the hands-on science and tehnology center: Philosophical reflections on learning in informal settings . Journal of Technology Education , 12(1), 49-60.

Watson, S., Dodd, J., \& Jones, C. (2007, September). Engage, learn, achieve. Retrieved September 17, 2008, from University of Leicester, Research Centre for Museums and Galleries: http://www.le.ac.uk/ms/research/Reports/EOE.pdf

Weinburgh, M. (1995). Gender differences in student attitudes toward science: A Meta-analysis of the literature from 1970 to 1991. Journal of Research in Science Teaching, 32(4), 387-398.

Weitze, M.-D. (2003). Science centers: Examples from the U.S. and from Germany. From the itinerant lecturers of the 18th century to popularizing physics in the 21st century-exploring the relationship between learning and entertainment, (pp. 1-7). Pognana sul Lario.

Wellington, J. (1990). Formal and informal learning in science: The role of interactive science centers. Physics Education , 247-250.

Yılmaz, Ö., Yalvaç, B., \& Tekkaya, C. (1998). Fen Bilgisi dersine ilişkin beceri ve tutumların ölçülmesi. Eğitim ve Bilim, 22, 45-50. 


\section{APPENDIX A}

\section{INFORMATION COLLECTION FORM}

\section{Bilgi Toplama Formu}

Sevgili öğrenciler,

Aşağıda sizinle ve ailenizle ilgili sorular yer almaktadır. Unutmayınız, verdiğiniz bilgiler sadece araştırma amacıyla kullanılacaktır ve verdiğiniz cevaplar kesinlikle gizli tutulacaktır. Lütfen soruları doğru olarak yanıtlayınız. Soruları doğru cevaplamanız çalışmaya önemli katkılar sağlayacaktır. Katkılarınızdan dolayı teşekkür ederim.

Adınız - Soyadınız

Cinsiyetiniz

Yaşınız

Sinıfinız

Geçen dönem Fen ve Teknoloji dersinden kaç aldınız? (X) işareti koyunuz.

5 (pekiyi)...... 4(iyi) ...... 3(orta) ...... 2(geçer) ...... 1(başarısız) ......

Babanızın yaptı̆̆

Annenizin yaptı̆̆ 1 iş nedir?

Kaç kardeşsiniz?

Oturduğunuz ev,

Size mi ait, kira mi?

Kaç oda, kaç salon?

Kaloriferli mi, sobalı mı?

Bahçeli bir ev mi, yoksa apartman dairesi mi?

Evinizde bilgisayar var mi?

Size ait bilgisayarınız var $\mathrm{m}$ ?

Internet bağlantısı var mi?

Bağımsız (size ait) bir çalışma odanız var mı?...

Arabanız var mı? Kaç tane? Modelleri ve yılları? 
ATTITUDES TOWARDS SCIENCE MEASURE

Table B.1: Attitude towards Science Measure

\begin{tabular}{|c|c|}
\hline No & Attitude Statements \\
\hline 1 & We learn interesting things in science lessons. \\
\hline 2 & I look forward to my science lessons. \\
\hline 3 & Science lessons are exciting. \\
\hline 4 & I would like to do more science at school. \\
\hline 5 & I like Science better than most other subjects at school. \\
\hline 6 & Science is boring. \\
\hline 7 & I find science difficult. \\
\hline 8 & I am just not good at Science. \\
\hline 9 & I get good marks in Science. \\
\hline 10 & I learn Science quickly. \\
\hline 11 & Science is one of my best subjects. \\
\hline 12 & I feel helpless when doing Science. \\
\hline 13 & In my Science class, I understand everything. \\
\hline 14 & Practical work in science is exciting. \\
\hline 15 & I like science practical work because you don't know what will happen. \\
\hline 16 & Practical work in science is good because I can work with my friends. \\
\hline 17 & I like practical work in science because I can decide what to do myself. \\
\hline 18 & I would like more practical work in my science lessons. \\
\hline 19 & We learn science better when we do practical work. \\
\hline 20 & I look forward to doing science practicals. \\
\hline 21 & Practical work in science is boring. \\
\hline 22 & I would like to join a science club. \\
\hline 23 & I like watching science programmes on TV. \\
\hline 24 & I like to visit science museums. \\
\hline 25 & I would like to do more science activities outside school. \\
\hline 26 & I like reading science magazines and books. \\
\hline 27 & It is exciting to learn about new things happening in science. \\
\hline 28 & I would like to study more science in the future. \\
\hline 29 & I would like to study science at university. \\
\hline 30 & I would like to have a job working with science. \\
\hline 31 & I would like to become a science teacher. \\
\hline 32 & I would like to become a scientist. \\
\hline 33 & Science and technology is important for society. \\
\hline 34 & Science and technology makes our lives easier and more comfortable. \\
\hline
\end{tabular}


Table B.1 (continued)

\begin{tabular}{|l|l}
\hline 35 & The benefits of science are greater than the harmful effects.
\end{tabular}

\begin{tabular}{l|l}
36 & Science and technology are helping the poor.
\end{tabular}

37 There are many exciting things happening in science and technology.

38 Scientists have exciting jobs.

39 I really like school.

$40 \quad$ I would recommend this school.

41 I find school boring.

\begin{tabular}{|l|l}
\hline 42 & I feel that I belong in this school. \\
\hline 43 & Most of
\end{tabular}

43 Most of the time I wish I wasn't in school at all.

$44 \quad$ I get on well with most of my teachers.

45 I am normally happy when I am in school.

\begin{tabular}{ll} 
I work as hard as I can in school. \\
\hline 46
\end{tabular} 


\section{APPENDIX C}

THE PERMISSION FOR THE USE OF THE ATTITUDE SCALE

To whom it may concern,

The researcher concerned may use the attitude to science measures developed by Patrick Barmby and colleagues in their research. We would appreciate the citation of the journal paper that it comes from in any subsequent publications.

Yours faithfully,

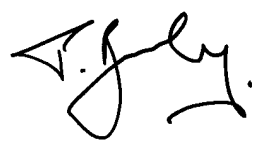

Dr. Patrick Barmby

Durham University 


\section{APPENDIX D}

\section{ATTITUDES TOWARDS SCIENCE MEASURE}

\section{Bilime Yönelik Tutum Ölçeği}

Sevgili öğrenciler, bu ölçek sizin bilime yönelik tutumlarınızı belirlemeyi amaçlamaktadır. Ölçekte, bilime yönelik tutum cümleleri ile her cümlenin karşısında Tamamen

Katılıyorum, Katılıyorum, Kararsızım, Katılmıyorum, Hiç Katılmıyorum seçenekleri yer almaktadır. Her bir cümleyi dikkatli okuyarak, boş bırakmadan, bu cümlelere ne ölçüde katıldığınızı seçeneklerden birine $(\mathbf{X})$ işareti koyarak belirtiniz. Bu cümlelerin doğru ya da yanlış cevapları bulunmamaktadır. Sizin doğru bulduğunuz cevaplar doğru kabul edilmektedir. Bu ölçek yalnızca araştırma amacıyla kullanılacaktır ve verdiğiniz cevaplar kesinlikle gizli tutulacaktır. Ölçeği içtenlik ve samimiyetle cevaplamanız çalışmaya önemli katkılar sağlayacaktır. Katkılarınızdan dolayı teşekkür ederim.

Eray ŞENTÜRK 
Table D.1 : Bilime Yönelik Tutum Ölçeği

\begin{tabular}{|c|c|c|c|c|c|}
\hline Tutum Cümleleri & 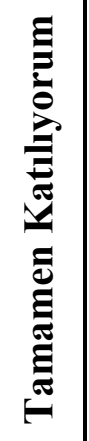 & 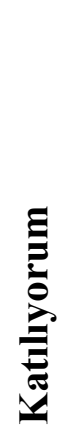 & 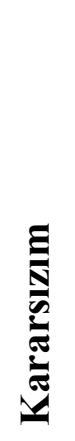 & 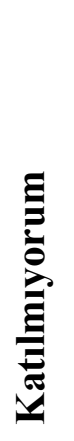 & 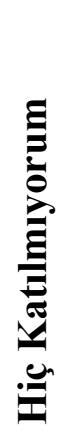 \\
\hline $\begin{array}{l}\text { 1.Fen ve Teknoloji derslerinde ilginç şeyler } \\
\text { öğreniriz. }\end{array}$ & & & & & \\
\hline 2.Fen ve Teknoloji derslerimi dört gözle beklerim. & & & & & \\
\hline 3.Fen ve Teknoloji dersleri heyecan vericidir. & & & & & \\
\hline $\begin{array}{l}\text { 4.Okulda, Fen ve Teknoloji dersiyle daha fazla } \\
\text { uğraşmak isterim. }\end{array}$ & & & & & \\
\hline $\begin{array}{l}\text { 5.Fen ve Teknoloji dersini, okuldaki çoğu dersten } \\
\text { daha çok severim. }\end{array}$ & & & & & \\
\hline 6.Fen ve Teknoloji dersi sıkıcıdır. & & & & & \\
\hline 7.Fen ve Teknoloji dersi, bence zor bir derstir. & & & & & \\
\hline 8.Fen ve Teknoloji dersinde iyi değilim. & & & & & \\
\hline 9.Fen ve Teknoloji dersinden iyi notlar alırım. & & & & & \\
\hline 10.Fen ve Teknoloji dersini çabucak öğrenirim. & & & & & \\
\hline $\begin{array}{l}\text { 11.Fen ve Teknoloji dersi, en iyi olduğum } \\
\text { derslerden biridir. }\end{array}$ & & & & & \\
\hline $\begin{array}{l}\text { 12.Fen ve Teknoloji dersiyle uğraşırken kendimi } \\
\text { çaresiz hissederim. }\end{array}$ & & & & & \\
\hline 13.Fen ve Teknoloji dersinde her şeyi anlarım. & & & & & \\
\hline $\begin{array}{l}\text { 14.Fen ve Teknoloji dersindeki etkinlikler heyecan } \\
\text { vericidir. }\end{array}$ & & & & & \\
\hline $\begin{array}{l}\text { 15.Fen ve Teknoloji dersindeki etkinlikleri } \\
\text { seviyorum. }\end{array}$ & & & & & \\
\hline $\begin{array}{l}\text { 16.Fen ve Teknoloji dersinde daha fazla etkinlik } \\
\text { yapılmasını isterim. }\end{array}$ & & & & & \\
\hline $\begin{array}{l}\text { 17.Etkinlik yaptığımız zaman, Fen ve Teknoloji } \\
\text { dersini daha iyi öğreniriz. }\end{array}$ & & & & & \\
\hline $\begin{array}{l}\text { 18.Fen ve Teknoloji dersinde etkinlik yapmayı dört } \\
\text { gözle beklerim. }\end{array}$ & & & & & \\
\hline $\begin{array}{l}\text { 19.Fen ve Teknoloji dersinde yapılan etkinlikler } \\
\text { sikıcidır. }\end{array}$ & & & & & \\
\hline
\end{tabular}


Table D.1 (continued)

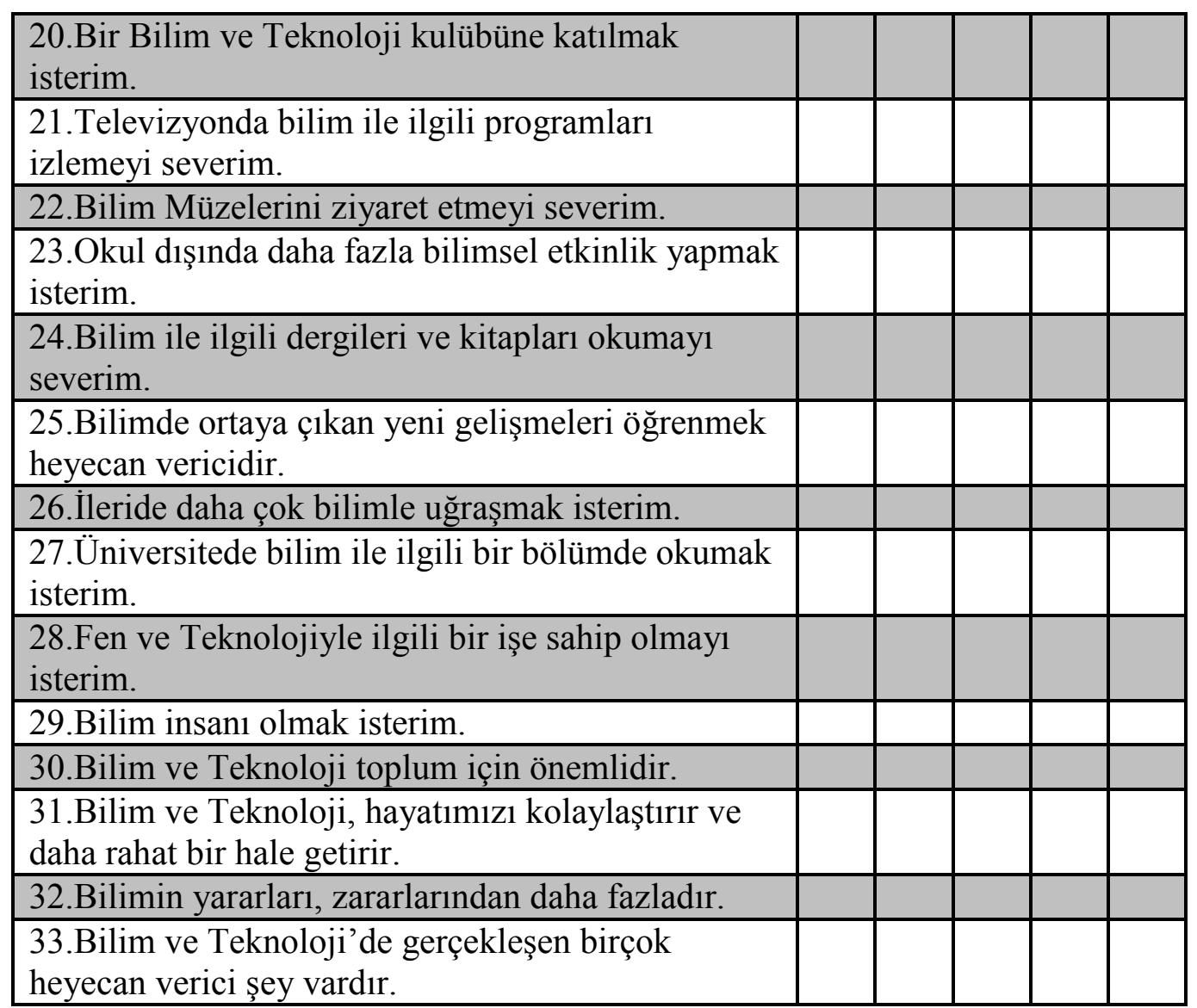


APPENDIX E

\section{THE PERMISSION GIVEN BY NATIONAL MINISTRY OF EDUCATION FOR THE RESEARCH}

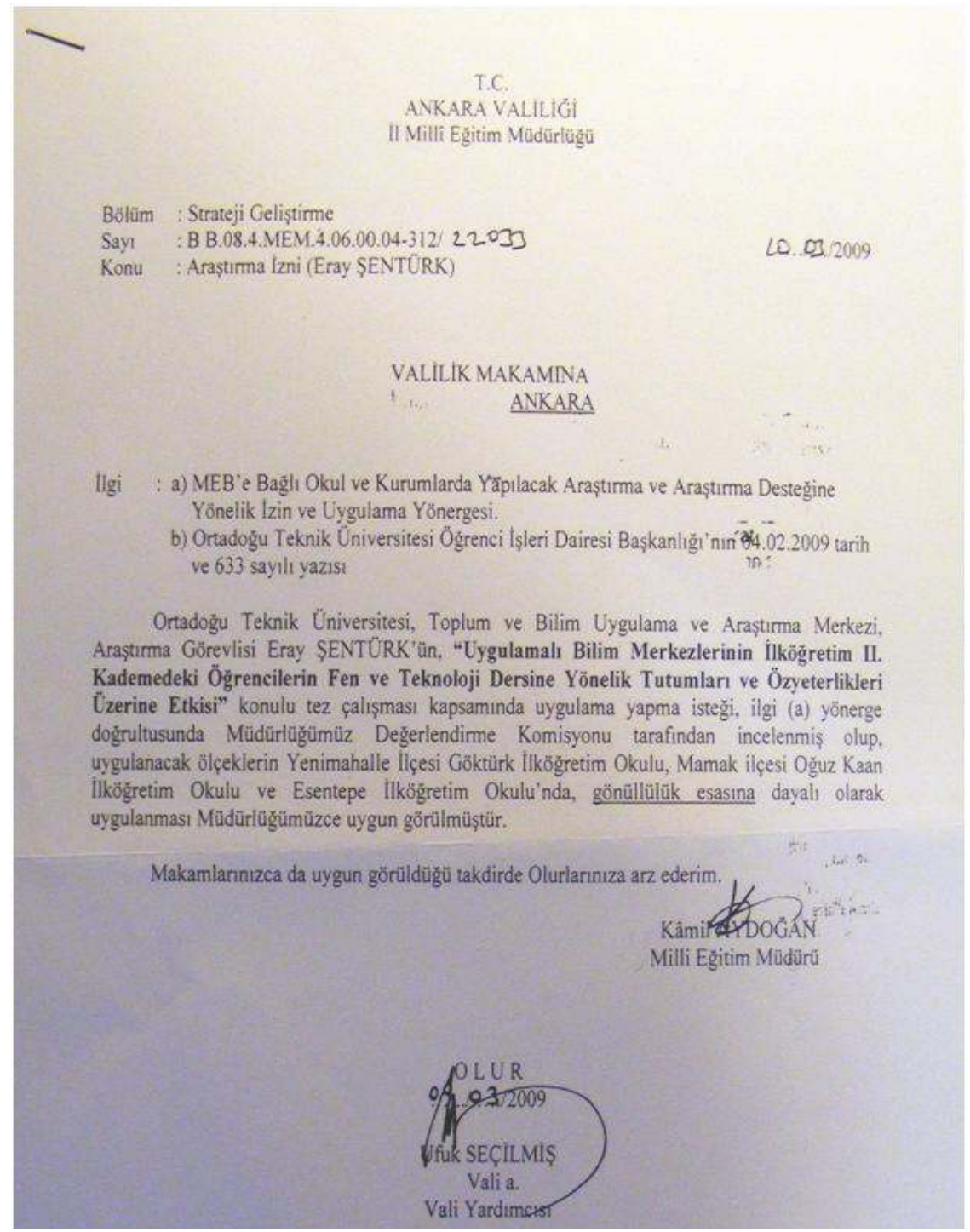




\section{APPENDIX F}

\section{VOLUNTARY PARTICIPATION FORM}

\section{Gönüllü Katılım Formu}

Bu çalışma, ODTÜ Eğitim Fakültesi Orta Öğretim Fen ve Matematik Alanları Eğitimi Bölümü (OFMA) Öğretim Görevlisi Yrd. Doç. Dr. Ömer Faruk ÖZDEMIR ve yüksek lisans öğrencisi Araştırma Görevlisi Eray ŞENTÜRK tarafından yürütülmektedir. Çalışmanın amacı, Orta Doğu Teknik Üniversitesi Uygulamalı Bilim Merkezini ziyaret eden İlköğretim ikinci kademedeki öğrencilerin, bilime yönelik tutumlarında bir değişiklik olup olmadığını belirlemektir. Çalışmaya katılım tamamılla gönüllüllük temelindedir. Araştırmada, sizden bir defaya mahsus "Bilgi Toplama Formu" doldurmanız istenecektir. Araştırma sırasında ise, farklı zamanlarda bilime yönelik tutum ölçeğini doldurmanız istenecektir. Cevaplarınız tamamen gizli tutulacak ve sadece araştırmacılar tarafindan değerlendirilecektir; elde edilecek bilgiler bilimsel yayınlarda kişisel bilgiler gizli kalmak koşulu ile kullanılacaktır. Katılım sırasında sorulardan ya da herhangi başka bir nedenden ötürü kendinizi rahatsız hissederseniz cevaplama işini yarıda bırakıp çıkmakta serbestsiniz. Böyle bir durumda uygulayan kişiye, ölçeği tamamlamadığınızı söylemek yeterli olacaktır. Ölçek uygulandıktan sonra, bu çalışmayla ilgili sorularınız cevaplanacaktır. Bu çalışmaya katıldığınız için şimdiden teşekkür ederiz. Çalışma hakkında daha fazla bilgi almak için Eğitim Fakültesi OFMA Bölümü Öğretim Görevlisi Yrd. Doç. Dr. Ömer Faruk ÖZDEMİR (Tel: 210 3691; E-posta: ozdemir@metu.edu.tr) ya da Arş. Gör. Eray ŞENTÜRK (Tel: 210 6053; E-posta: esenturk@metu.edu.tr ile iletişim kurabilirsiniz.

Bu çalışmaya tamamen gönülllü olarak kattlyyorum ve istediğim zaman yarıda kesip çıkabileceğimi biliyorum. Verdiğim bilgilerin bilimsel amaçlı yayımlarda kullanılmasını kabul ediyorum. (Formu doldurup imzaladıktan sonra uygulayıcıya geri veriniz). İsim Soyadı Tarih İmza 


\section{APPENDIX G}

\section{PARENT'S CONSENT FORM FOR EXPERIMENTAL GROUP}

\section{Veli Onay Mektubu}

\section{Sayın Veli,}

Bu çalışma, Orta Doğu Teknik Üniversitesi (ODTÜ) Eğitim Fakültesi Orta Öğretim Fen ve Matematik Alanları Eğitimi Bölümü (OFMA) Öğretim Görevlisi Yrd. Doç. Dr. Ömer Faruk ÖZDEMIR ve yüksek lisans öğrencisi Araştırma Görevlisi Eray ŞENTÜRK tarafından yürütülmektedir. Çalışmanın amacı: Orta Doğu Teknik Üniversitesi Uygulamalı Bilim Merkezi'ni ziyaret eden İlköğretim öğrencilerinin, bilime yönelik tutumlarında olumlu yönde bir değişiklik olup olmadığını belirlemektir. Çalışmanın temelde yararları: katılımcıların bilime yönelik meraklarının uyandırılması, bilime yönelik isteklendirilmeleri, kendilerinin bilim yapabilecekleri, ileride bir bilim insanı olabilecekleri, kendi potansiyellerini küçümsememeleri gerektiği inancının kazandırılmasıdır. Katılımcılara, araştırmanın ilk uygulamasında bir defaya mahsus "Bilgi Toplama Formu" verilecektir. "Bilgi Toplama Formu" katılımcıların cinsiyeti, yaşı, kardeş sayısı gibi soruları içermektedir. Araştırma esnasında, katılımcılara bilime yönelik tutum cümleleri içeren ölçek uygulanacaktır. Katılımcıların 1 hafta aralıklarla bu ölçeği 2 kere okullarındaki sınıflarında doldurması, 1 kere ODTÜ Uygulamalı Bilim Merkezi'nde doldurması beklenmektedir. Çalışmanın ikinci ölçek uygulaması kısmında katılımcılar, ODTÜ Uygulamalı Bilim Merkezi ziyaretine öğretmenleri gözetiminde gelecektir. Burada katılımcılar, bir bilim gösterisi seyredecekler, daha sonra da kendileri deneyleri uygulayacaklardır. Yapılan ziyaretten sonra ölçeği doldurmaları istenecektir. Çalışmaya katılım tamamıyla gönüllülük temelindedir. Katılımcıların cevapları tamamen gizli tutulacak ve sadece araştırmacılar tarafından değerlendirilecektir; elde edilecek bilgiler bilimsel yayınlarda kişisel bilgiler gizli kalmak koşulu ile kullanılacaktır. Katılım sırasında sorulardan ya da herhangi başka bir nedenden ötürü katılımcı kendisini rahatsız hissederse, 
cevaplama işini yarıda bırakıp çıkmakta serbesttir. Böyle bir durumda uygulayan kişiye, ölçeği tamamlamadığını söylemesi yeterli olacaktır. Bu çalışmaya verdiğiniz destek için şimdiden teşekkür ederiz. Çalışma hakkında daha fazla bilgi almak için ODTÜ Eğitim Fakültesi OFMA Bölümü Öğretim Görevlisi Yrd. Doç. Dr. Ömer Faruk ÖZDEMİR (Tel: 210 3691; E-posta: ozdemir@metu.edu.tr) ya da Arş. Gör. Eray ŞENTÜRK (Tel: 210 6053; E-posta: esenturk@metu.edu.tr) ile iletişim kurabilirsiniz.

Araştırmacının Adı-Soyadı : Eray ŞENTÜRK İmzası :

Adresi : Orta Doğu Teknik Üniversitesi (ODTÜ) Toplum ve Bilim Merkezi (TBM) Bilim ve Teknoloji Müzesi (BTM) Cam Silo 06531 / Ankara / TÜRKIYE

Telefon: (+90) 3122106053

Yukarıda açıklamasını okuduğum çalışmaya, oğlum/kızım

'nin katılımına izin veriyorum. Ebeveynin:

Ad1, soyad1: İmzas1: Tarih:

İmzalanan bu formu lütfen oğlunuz/kızınız aracılı̆̆ ile Fen ve Teknoloji

Öğretmeni’ne ulaștırınız.

Çocuğunuzun katılımı ya da haklarının korunmasına yönelik sorularınız varsa ya da çocuğunuz herhangi bir şekilde risk altında olabileceğine, strese maruz kalacağına inanıyorsanız; Orta Doğu Teknik Üniversitesi Etik Kuruluna (312) 210-37 29 telefon numarasından ulaşabilirsiniz. 


\section{APPENDIX H}

\section{PARENT'S CONSENT FORM FOR CONTROL GROUP}

\section{Veli Onay Mektubu}

\section{Sayın Veli,}

$\mathrm{Bu}$ çalışma, Orta Doğu Teknik Üniversitesi (ODTÜ) Eğitim Fakültesi Orta Öğretim Fen ve Matematik Alanları Eğitimi Bölümü (OFMA) Öğretim Görevlisi Yrd. Doç. Dr. Ömer Faruk ÖZDEMİR ve yüksek lisans öğrencisi Araştırma Görevlisi Eray ŞENTÜRK tarafından yürütülmektedir. Çalışmanın amacı: Orta Doğu Teknik Üniversitesi Uygulamalı Bilim Merkezi'ni ziyaret eden İlköğretim öğrencilerinin, bilime yönelik tutumlarında olumlu yönde bir değişiklik olup olmadığını belirlemektir. Çalışmanın temelde yararları: katılımcıların bilime yönelik meraklarının uyandırılması, bilime yönelik isteklendirilmeleri, kendilerinin bilim yapabilecekleri, ileride bir bilim insanı olabilecekleri, kendi potansiyellerini küçümsememeleri gerektiği inancının kazandırılmasıdır. Katılımcılara, araştırmanın ilk uygulamasında bir defaya mahsus "Bilgi Toplama Formu" verilecektir. "Bilgi Toplama Formu" katılımcıların cinsiyeti, yaşı, kardeş sayısı gibi soruları içermektedir. Araştırma esnasında, katılımcılara bilime yönelik tutum cümleleri içeren ölçek uygulanacaktır. Katılımcıların 1 hafta aralıklarla bu ölçeği 3 kere, okullarındaki sınıflarında doldurması beklenmektedir. Çalışmaya katılım tamamıla gönüllülük temelindedir. Katılımcıların cevapları tamamen gizli tutulacak ve sadece araştırmacılar tarafından değerlendirilecektir; elde edilecek bilgiler bilimsel yayınlarda kişisel bilgiler gizli kalmak koşulu ile kullanılacaktır. Katılım sırasında sorulardan ya da herhangi başka bir nedenden ötürü katılımcı kendisini rahatsız hissederse, cevaplama işini yarıda bırakıp çıkmakta serbesttir. Böyle bir durumda uygulayan kişiye, ölçeği tamamlamadığını söylemesi yeterli olacaktır. $\mathrm{Bu}$ çalışmaya verdiğiniz destek için şimdiden teşekkür ederiz. Çalışma hakkında daha fazla bilgi almak için Eğitim Fakültesi OFMA Bölümü Öğretim Görevlisi Yrd. Doç. Dr. Ömer Faruk ÖZDEMİR (Tel: 210 3691; 
E-posta: ozdemir@metu.edu.tr) ya da Arş. Gör. Eray ŞENTÜRK (Tel: 210 6053; E-posta: esenturk@metu.edu.tr) ile iletişim kurabilirsiniz.

Araştırmacının Adı-Soyadı : Eray ŞENTÜRK İmzası :

Adresi : Orta Doğu Teknik Üniversitesi (ODTÜ) Toplum ve Bilim Merkezi (TBM) Bilim ve Teknoloji Müzesi (BTM) Cam Silo 06531 / Ankara / TÜRKIYE

Telefon: (+90) 3122106053

Yukarıda açıklamasını okuduğum çalışmaya, oğlum/kızım 'nın/nin katılımına izin veriyorum. Ebeveynin:

Ad1, soyad1: İmzas1: Tarih:

İmzalanan bu formu lütfen oğlunuz/kızınız aracılı̆̆ı ile Fen ve Teknoloji Öğretmeni’ne ulaștırınız.

Çocuğunuzun katılımı ya da haklarının korunmasına yönelik sorularınız varsa ya da çocuğunuz herhangi bir şekilde risk altında olabileceğine, strese maruz kalacağına inanıyorsanız; Orta Doğu Teknik Üniversitesi Etik Kuruluna (312) 210-37 29 telefon numarasından ulaşabilirsiniz. 


\section{MEANS, STANDARD DEVIATIONS, ROTATED FACTOR LOADINGS,} AND COMMUNALITIES FOR ATTITUDE SCALE

Table I. 1: Means, Standard Deviations, Rotated Factor Loadings, and Communalities for Attitude Scale

\begin{tabular}{|c|c|c|c|c|c|c|c|c|c|}
\hline \multirow{2}{*}{$\begin{array}{c}\text { Item } \\
\text { No }\end{array}$} & \multirow[b]{2}{*}{ M } & \multicolumn{8}{|c|}{ Factor Loadings } \\
\hline & & SD & 1 & 2 & 3 & 4 & 5 & 6 & $h^{2}$ \\
\hline 9 & 4.32 & .81 & .83 & & & .16 & & .12 & .50 \\
\hline 11 & 3.76 & 1.06 & .81 & .15 & .12 & .19 & .25 & & .73 \\
\hline 10 & 3.71 & 1.17 & .76 & .29 & & .25 & .10 & & .79 \\
\hline 8 & 3.72 & 1.19 & .74 & .19 & & .13 & .10 & & .68 \\
\hline 12 & 4.48 & .81 & .67 & .18 & & .24 & & & .68 \\
\hline 7 & 3.46 & 1.25 & .65 & .11 & .10 & & .28 & & .69 \\
\hline 13 & 4.18 & 1.07 & .59 & .29 & & .29 & & & .80 \\
\hline 21 & 3.36 & 1.36 & & .77 & .17 & & .28 & .18 & .68 \\
\hline 24 & 3.71 & 1.25 & .17 & .75 & & .18 & .11 & .19 & .68 \\
\hline 20 & 3.70 & 1.06 & .21 & .72 & .17 & .26 & .11 & & .74 \\
\hline 22 & 3.64 & 1.11 & .22 & .68 & .12 & & .15 & .16 & .74 \\
\hline 25 & 3.62 & 1.24 & .17 & .68 & & .13 & .27 & .12 & .79 \\
\hline 23 & 4.10 & 1.10 & .20 & .67 & .15 & & .32 & & .76 \\
\hline 18 & 3.42 & 1.04 & & .15 & .83 & .23 & .10 & .13 & .53 \\
\hline 16 & 4.09 & 1.15 & & .24 & .83 & .11 & & .10 & .75 \\
\hline 17 & 4.25 & 1.05 & .12 & & .80 & & -.14 & .14 & .81 \\
\hline 15 & 4.30 & 1.03 & & .14 & .74 & .35 & .22 & .15 & .77 \\
\hline 19 & 4.32 & 1.10 & & & 68 & .23 & & & .72 \\
\hline 14 & 3.96 & 1.21 & & .31 & .61 & .52 & & & .80 \\
\hline 3 & 4.23 & 1.17 & .22 & & .25 & .81 & & & .72 \\
\hline 2 & 3.40 & 1.39 & .30 & & .16 & .76 & .18 & & .68 \\
\hline 6 & 4.00 & 1.26 & .20 & .16 & .23 & .71 & .21 & & .74 \\
\hline 5 & 4.16 & 1.21 & .40 & & .27 & .57 & .33 & & .61 \\
\hline 4 & 4.02 & 1.13 & .38 & .29 & .30 & .57 & .18 & & .62 \\
\hline 1 & 4.10 & 1.08 & .34 & & .29 & .41 & .32 & .11 & .68 \\
\hline
\end{tabular}


Table I.1 (continued)

\begin{tabular}{llllllllll}
\hline 28 & 4.29 & 1.05 & .22 & .23 & & .16 & $\mathbf{. 8 1}$ & & .63 \\
27 & 3.75 & 1.26 & .16 & .34 & & .24 & $\mathbf{. 8 0}$ & .11 & .78 \\
29 & 3.59 & 1.29 & & .33 & & .13 & $\mathbf{. 7 7}$ & .20 & .86 \\
26 & 3.54 & 1.34 & .23 & .47 & .12 & .17 & $\mathbf{. 6 7}$ & .10 & .81 \\
31 & 3.52 & 1.31 & & .12 & .13 & & & $\mathbf{. 8 1}$ & .76 \\
32 & 4.71 & .65 & .13 & .12 & .21 & & &. $\mathbf{7 3}$ & .60 \\
33 & 4.66 & .65 & & .31 & .10 & .28 & .20 & $\mathbf{. 6 7}$ & .70 \\
30 & 4.62 & .62 & .12 & .10 & .11 & & & $\mathbf{. 5 8}$ & .67 \\
\hline
\end{tabular}

Note. Boldface indicates highest factor loadings. Description of items found in Appendix D. $\mathrm{h} 2=$ communality. 
APPENDIX J

\section{EIGENVALUES, PERCENTAGES OF VARIANCE, AND CUMULATIVE PERCENTAGES FOR FACTORS OF THE 33-ITEM ATTITUDE SCALE}

Table J. 1: Eigenvalues, Percentages of Variance, and Cumulative Percentages for Factors of the 33-Item Attitude Scale

\begin{tabular}{cccc}
\hline Factor & Eigenvalue & \% of Variance & Cumulative \% \\
\hline 1 & 12.7 & 38.6 & 38.6 \\
2 & 3.5 & 10.6 & 49.2 \\
3 & 2.9 & 8.7 & 57.9 \\
4 & 1.7 & 5.1 & 63.0 \\
5 & 1.5 & 4.7 & 67.7 \\
6 & 1.2 & 3.5 & 71.2 \\
\hline
\end{tabular}




\section{APPENDIX K}

\section{EXAMINATION OF STUDENTS' CHARACTERISTICS FOR INTERNAL VALIDITY}

During the interview with the school manager and teachers it was reported that socioeconomic status and ethnicity of the control and experiment groups are similar therefore these characteristics are unlikely to be an important threat to the internal validity of the study.

In the experimental group, 20 out of 46 students were male and 26 of them were female. In the control group, 27 of 46 students were male and 19 of them were female. Therefore, the groups were not very similar with respect to gender. The independent t-tests were conducted to compare males' and females' attitudes scores on the pre-test in both groups, and it was found that there is a significant difference between males in the experimental group and those in control group $[\mathrm{M}=132.45, \mathrm{SD}=16.34$ for experimental group, $\mathrm{M}=118.37, \mathrm{SD}=24.77$ for control group, $\mathrm{t}(44.51)=2.34, \mathrm{p}=.024]$, and however, it was found that there is no significant difference between females in experimental group and those in control group $[M=129.85, S D=25.89$ for experimental group, $M=132, S D=16.89$ for control group, $\mathrm{t}(90)=-.316, \mathrm{p}=.753]$. These results suggest that the gender characteristic is likely effective to be a threat.

The students' previous science knowledge determined at beginning of the study by means of "Information Collection Form", and it was found that there was no significant difference between the groups with respect to previous science 
knowledge $[\mathrm{M}=3.72, \mathrm{SD}=1.13$ for experimental group, $\mathrm{M}=3.30, \mathrm{SD}=1.07$ for control group $\mathrm{t}(90)=1.80, \mathrm{p}=.075]$.

The independent t-tests were also conducted to compare attitude scores for experimental and control group. There was no significant difference in overall attitude scores for experimental $(\mathrm{M}=130.98, \mathrm{SD}=22.07)$ and control group $[\mathrm{M}=$ $124, \mathrm{SD}=22.68, \mathrm{t}(90)=1.5, \mathrm{p}=.14]$.

Similarly, there was no significant difference in attitude scores with respect to six factors of the attitude scale for experimental and control groups (see Table K.1).

Table K.1: T-test results with respect to factors of the attitude scale for both groups

\begin{tabular}{cccccccc}
\hline & \multicolumn{2}{c}{ Experimental } & \multicolumn{2}{c}{ Control } & & & \\
& Group & \multicolumn{2}{c}{ Group } & & & \\
& $\mathrm{M}$ & $\mathrm{SD}$ & $\mathrm{M}$ & $\mathrm{SD}$ & $\mathrm{t}$ & $\mathrm{df}$ & $\mathrm{p}$ \\
\hline Self-concept in science & 22.59 & 5.26 & 23.52 & 5.70 & 1.80 & 90 & .074 \\
Science outside of school & 24.41 & 5.03 & 23.13 & 5.66 & 1.15 & 90 & .254 \\
Practical work in science & 25.33 & 5.80 & 24.02 & 5.72 & 1.09 & 90 & .280 \\
Learning science in school & 23.91 & 4.60 & 22.65 & 4.79 & 1.29 & 90 & .201 \\
Future participation in science & 15.17 & 3.64 & 14.02 & 4.48 & 1.36 & 90 & .179 \\
Importance of science & 16.57 & 2.93 & 16.65 & 3.76 & -.124 & 90 & .902 \\
\hline
\end{tabular}

